\title{
The Effects of Carbohydrates, in Isolation and Combined with Caffeine, on Cognitive Performance and Mood-Current Evidence and Future Directions
}

\author{
Neil Bernard Boyle * (1), Clare Louise Lawton and Louise Dye (i) \\ Leeds Nutrition and Behaviour Group, School of Psychology, University of Leeds, Leeds LS2 9JT, UK; \\ c.l.lawton@leeds.ac.uk (C.L.L.); 1.dye@leeds.ac.uk (L.D.) \\ * Correspondence: n.b.boyle@leeds.ac.uk; Tel. \& Fax: +44-0-113-343-1403
}

Received: 2 January 2018; Accepted: 26 January 2018; Published: 9 February 2018

\begin{abstract}
This review examines the effects of carbohydrates, delivered individually and in combination with caffeine, on a range of cognitive domains and subjective mood. There is evidence for beneficial effects of glucose at a dose of $25 \mathrm{~g}$ on episodic memory, but exploration of dose effects has not been systematic and the effects on other cognitive domains is not known. Factors contributing to the differential sensitivity to glucose facilitation include age, task difficulty/demand, task domain, and glucoregulatory control. There is modest evidence to suggest modulating glycemic response may impact cognitive function. The evidence presented in this review identifies dose ranges of glucose and caffeine which improve cognition, but fails to find convincing consistent synergistic effects of combining caffeine and glucose. Whilst combining glucose and caffeine has been shown to facilitate cognitive performance and mood compared to placebo or glucose alone, the relative contribution of caffeine and glucose to the observed effects is difficult to ascertain, due to the paucity of studies that have appropriately compared the effects of these ingredients combined and in isolation. This review identifies a number of methodological challenges which need to be considered in the design of future hypothesis driven research in this area.
\end{abstract}

Keywords: carbohydrate; caffeine; cognitive performance; subjective mood; glycemic response; glucose

\section{Introduction}

The potential facilitative effects of carbohydrates (CHOs) on cognitive performance were first proposed in the 1950s [1]. Since then the capacity of CHO intake to enhance cognitive performance, or attenuate cognitive impairment, has been widely examined. A rise in the popularity of "energy" drinks that combine $\mathrm{CHOs}$ with caffeine, and claim to offer beneficial performance effects, has resulted in a growing literature examining the cognitive effects of combining $\mathrm{CHO}$ with caffeine. This review outlines the existing evidence of the capacity of $\mathrm{CHOs}$ in isolation and combined with caffeine to offer facilitative cognitive performance effects. Evidence of the effects these ingredients on measures of subjective mood will also be examined.

Table 1 summarizes the cognitive domains commonly employed in studies that have examined the effects of $\mathrm{CHO}$ intake on cognitive performance. Tests of cognitive function measure a range of cognitive modalities, including memory, attention and vigilance, information processing, and accuracy and speed of response [2]. These tasks tend to measure components of performance that may tap into more complex skills; for example, psychomotor skill may be a proxy measure of driving performance [3]. 
Table 1. Summary of cognitive domains and associated tasks commonly employed in the literature on carbohydrate (CHO).

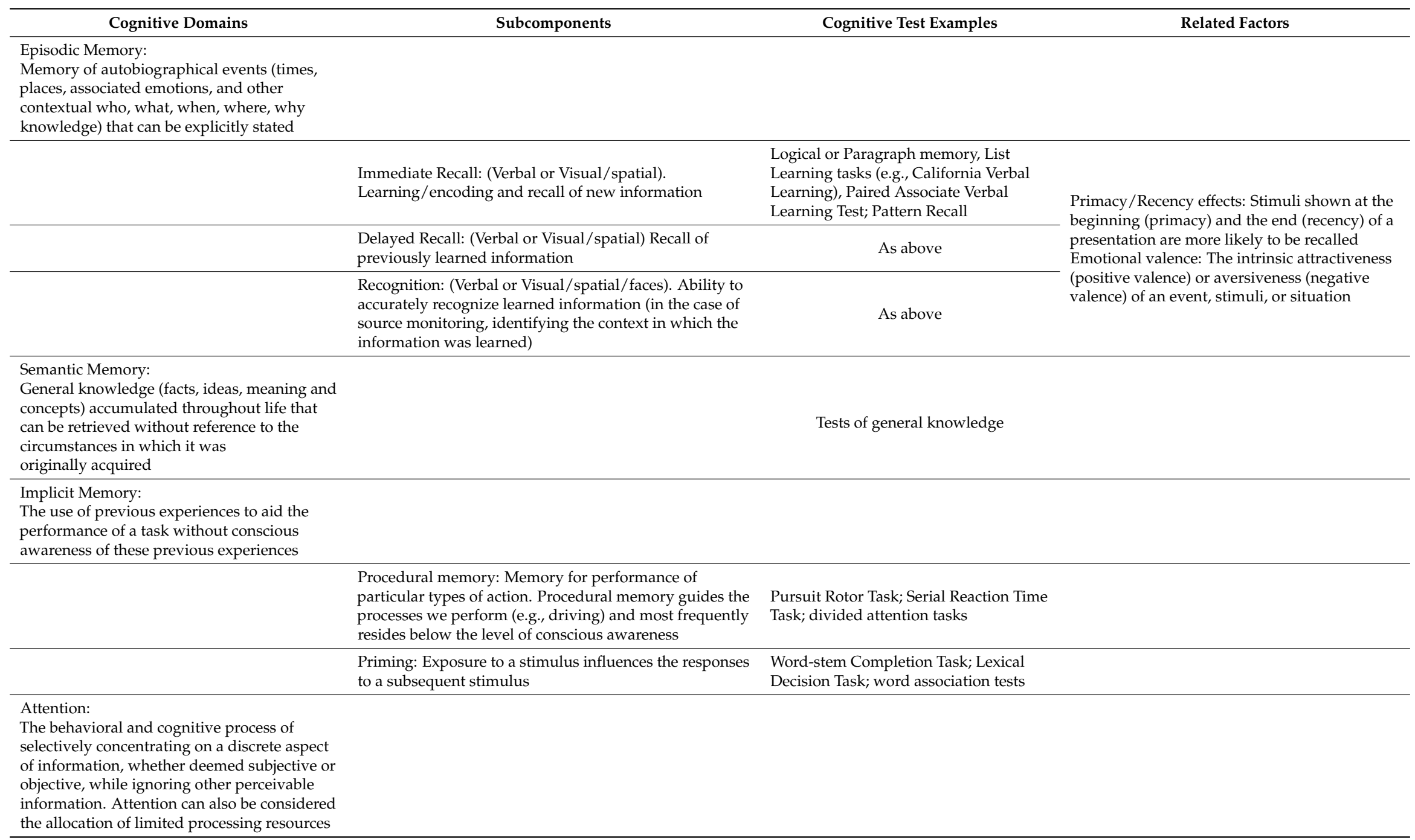


Table 1. Cont.

\begin{tabular}{|c|c|c|c|}
\hline Cognitive Domains & Subcomponents & Cognitive Test Examples & Related Factors \\
\hline & $\begin{array}{l}\text { Attentional Capacity: Accuracy of attention span (e.g., } \\
\text { repeating digit sequence) }\end{array}$ & $\begin{array}{l}\text { Digit Span (especially Digits Forward); } \\
\text { Digit Symbol Substitution (DSST) }\end{array}$ & \multirow{3}{*}{$\begin{array}{l}\text { Divided attention/multi-tasking: the } \\
\text { performance of multiple tasks concurrently to } \\
\text { apply extra demand/load on } \\
\text { attentional resources }\end{array}$} \\
\hline & $\begin{array}{l}\text { Vigilance/Focus: Sustaining attention over time to detect } \\
\text { target stimuli, often with a demand to ignore distractors }\end{array}$ & $\begin{array}{l}\text { Repeated Digits Vigilance, Continuous } \\
\text { Performance, Bakan/Rapid Visual } \\
\text { Information Processing (RVIP); } \\
\text { Digit/Letter Cancellation }\end{array}$ & \\
\hline & $\begin{array}{l}\text { Processing/Perceptual Speed: Ability to process } \\
\text { information and execute relevant operations within the } \\
\text { allotted time }\end{array}$ & $\begin{array}{l}\text { Trail-making Test (Part A and B); } \\
\text { Simple/Choice Reaction time }\end{array}$ & \\
\hline \multirow[t]{5}{*}{$\begin{array}{l}\text { Executive Functions: } \\
\text { An umbrella term for the management } \\
\text { (regulation, control) of cognitive processes, } \\
\text { including working memory, reasoning, task } \\
\text { flexibility, and problem solving as well as } \\
\text { planning and execution }\end{array}$} & & & \\
\hline & $\begin{array}{l}\text { Reasoning/Planning: Thinking with conscious intent to } \\
\text { reach a conclusion (planning involves induction, } \\
\text { reasoning is more deductive) }\end{array}$ & $\begin{array}{l}\text { Graduate and Managerial Assessment } \\
\text { Test of Abstract Reasoning; Tower } \\
\text { of Hanoi }\end{array}$ & \\
\hline & $\begin{array}{l}\text { Inhibitory Control/Self-control: Effortful inhibition of } \\
\text { predominant responses, emotions, thoughts, and } \\
\text { impulses, permitting behavior to vary adaptively } \\
\text { moment to moment }\end{array}$ & $\begin{array}{l}\text { Attention-switching tests; Go/No-Go; } \\
\text { Stroop Color and Word Test }\end{array}$ & \\
\hline & $\begin{array}{l}\text { Working Memory: Allows information maintained in } \\
\text { temporary storage to be manipulated for complex } \\
\text { cognitive operations }\end{array}$ & $\begin{array}{l}\text { Paced Auditory Serial Addition Task; } \\
\text { Serial 3s, Serial 7s; Brown Peterson } \\
\text { Trigrams; Corsi Block Tapping }\end{array}$ & \\
\hline & $\begin{array}{l}\text { Problem-solving: Using generic or ad hoc methods, in an } \\
\text { orderly manner, for finding solutions to problems }\end{array}$ & $\begin{array}{l}\text { Anagram Tasks; Mathematical } \\
\text { Problem Solving }\end{array}$ & \\
\hline \multicolumn{4}{|l|}{$\begin{array}{l}\text { Language: } \\
\text { Ability to speak or perform in an acquired } \\
\text { language }\end{array}$} \\
\hline & $\begin{array}{l}\text { Verbal Fluency: Oral production of words fitting a } \\
\text { specified category (e.g., animals) or beginning with a } \\
\text { specified letter }\end{array}$ & Category Fluency; Phonemic fluency & \\
\hline & $\begin{array}{l}\text { Verbal Reasoning: Ability to read and think about } \\
\text { information presented and apply logic to determine } \\
\text { whether specific conclusions can be drawn from } \\
\text { the information }\end{array}$ & Verbal Reading-Comprehension Test & \\
\hline
\end{tabular}


Table 1. Cont.

\begin{tabular}{|c|c|c|c|}
\hline Cognitive Domains & Subcomponents & Cognitive Test Examples & Related Factors \\
\hline \multicolumn{4}{|l|}{$\begin{array}{l}\text { Motor Performance: } \\
\text { Movements and motions carried out by } \\
\text { co-ordination of the brain, nervous system, } \\
\text { and muscles }\end{array}$} \\
\hline & Gross motor speed: Speeded gross manual dexterity & Simple tapping task & $\begin{array}{l}\text { Driving: Measures of driving performance } \\
\text { require fine, gross and psychomotor skills }\end{array}$ \\
\hline & Fine motor speed: Speeded fine manual dexterity & Grooved Pegboard & \\
\hline & $\begin{array}{l}\text { Psychomotor skill: The physical encoding of information, } \\
\text { with movement and/or with activities where the gross } \\
\text { and fine muscles are used for expressing or interpreting } \\
\text { information or concepts }\end{array}$ & $\begin{array}{l}\text { Psychomotor Vigilance Task (PVT); } \\
\text { throwing; manipulation of objects }\end{array}$ & \\
\hline \multicolumn{4}{|l|}{$\begin{array}{l}\text { Reaction Time (RT): } \\
\text { Speed of a response (in seconds or } \\
\text { milliseconds) to a cue, stimulus or event }\end{array}$} \\
\hline & $\begin{array}{l}\text { Simple RT: Speed of response to a target (e.g., pressing a } \\
\text { button when a cross appears) }\end{array}$ & Simple Reaction Time Test & \multirow{2}{*}{$\begin{array}{l}\text { Note: RT can be used as an index of } \\
\text { performance on other domains of cognitive } \\
\text { function (e.g., speed of recalling words, speed of } \\
\text { working memory performance) }\end{array}$} \\
\hline & $\begin{array}{l}\text { Choice RT: Analogous to simple RT except that stimulus } \\
\text { and response uncertainty are introduced by having } \\
\text { multiple possible stimuli and responses }\end{array}$ & 2-choice Reaction Time Test & \\
\hline $\begin{array}{l}\text { VisuoSpatial Function: } \\
\text { The ability to comprehend and conceptualize } \\
\text { visual representations and spatial } \\
\text { relationships in learning and performing } \\
\text { a task }\end{array}$ & & $\begin{array}{l}\text { Judgment of Line Orientation Test; Clock } \\
\text { Test; Hooper Visual Organization Task }\end{array}$ & \\
\hline
\end{tabular}




\section{Carbohydrates and Cognitive Function}

\subsection{Glucose}

Glucose is the primary monosaccharide in mammalian metabolism and most abundant dietary sugar-accounting for $\sim 80 \%$ of the end product of $\mathrm{CHO}$ digestion [4]. Glucose is virtually the sole fuel for the brain except during prolonged starvation when liver ketone bodies are oxidized. Due to the inability to store fuel the brain requires a continual supply of glucose, an estimated $120 \mathrm{~g}$ per day [5]. Glucose is by far the most systematically examined $\mathrm{CHO}$ in relation to the moderation of cognitive function, and forms a prototypical research model of the nutrition-behavior axis. The facilitative effects of glucose on cognitive performance have been investigated in diverse populations (e.g., adolescents [6]), young adults [7,8], older adults [9] and individuals with cognitive impairments [10] and dementia [11]).

To date, examination of the effects of glucose facilitation has predominantly focused upon episodic memory. Table 2 highlights that the most consistent effects of glucose have been demonstrated in this cognitive domain. Evidence of the facilitation of episodic memory suggests a specific enhancing effect of glucose intake on cognitive domains associated with the function of the hippocampus. In support of this, facilitative effects have also been reported for additional hippocampal-dependent cognitive functions: recognition memory [12-16]; visuospatial memory [17,18] and visuospatial functioning $[19,20]$.

However, glucose enhancement of cognitive domains that are not closely associated with hippocampal function has also been demonstrated. For example, processing speed and reaction time [21], working memory [13,22,23]; problem solving [24] and attention [25-28] have all been shown to be sensitive to an acute glucose load.

\subsection{Factors Moderating the Effect of Glucose}

Examination of the study outcomes shown in Table 2 shows that whilst the enhancement of episodic memory has been the most consistently reported outcome, no effect of acute glucose intake is often reported, even when comparable doses and cognitive tests are employed (e.g., [29-32]). This inconsistency in the facilitative effect of glucose administration is evident both across and within cognitive domains. Such heterogeneity in the evidence suggests a role for additional factors mediating the relationship between glucose and cognitive function. 
Table 2. Summary of studies examining the effects of glucose on cognitive performance domains and mood.

\begin{tabular}{|c|c|c|c|c|c|c|c|c|c|c|c|c|c|c|c|c|c|c|}
\hline \multirow[b]{2}{*}{ Authors } & \multirow[b]{2}{*}{$\begin{array}{l}\text { Sample Size } \\
\text { (Age) }\end{array}$} & \multirow[b]{2}{*}{$\begin{array}{l}\text { Dose } \\
\text { (Glucose) }\end{array}$} & \multirow[b]{2}{*}{$\begin{array}{c}\text { Design } \\
\text { (Within or } \\
\text { Between Subjects) }\end{array}$} & \multicolumn{15}{|c|}{ Cognitive Outcomes } \\
\hline & & & & 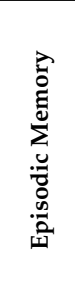 & 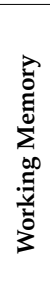 & 泀 & 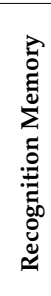 & 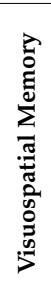 & 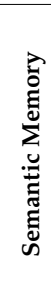 & 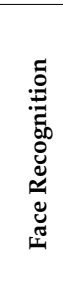 & 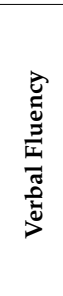 & 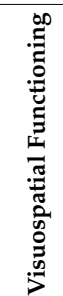 & 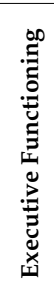 & 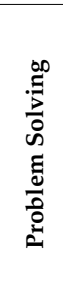 & 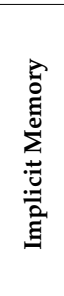 & 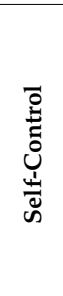 & 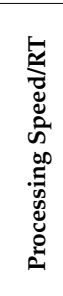 & 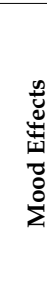 \\
\hline Hall et al. 1989 [22] & $\begin{array}{c}12(M=20) \\
11(M=67.4)\end{array}$ & $\begin{array}{l}50 \mathrm{~g} \\
50 \mathrm{~g}\end{array}$ & $\begin{array}{c}\text { Within } \\
\text { (overnight fast) } \\
\text { Within } \\
\text { (overnight fast) }\end{array}$ & $\overline{\mathrm{O}}$ & $\begin{array}{l}\mathrm{O} \\
-\end{array}$ & & & $\begin{array}{l}- \\
-\end{array}$ & & & & & & & & & & \\
\hline Benton, 1990 [33] & $\begin{array}{c}20+40 \\
(M=20.4 \& \\
21.05)\end{array}$ & $25 \mathrm{~g}$ & Between ( $4 \mathrm{~h}$ fast) & & & $\mathbf{O}$ & & & & & & & & & & & & \\
\hline Azari, 1991 [29] & $18(M=21)$ & $30 \mathrm{~g}$ & Within (10 h fast) & - & & & - & & & & & & & & & & & \\
\hline Azari, 1991 [29] & $18(M=21)$ & $100 \mathrm{~g}$ & Within (10 h fast) & - & & & - & & & & & & & & & & & \\
\hline Benton \& Owens, 1993 [30] & $\begin{array}{l}100(M=21.7) \\
53(M=21.5)\end{array}$ & $\begin{array}{c}50 \mathrm{~g} \\
50 \mathrm{~g}(+25 \mathrm{~g} \mathrm{at}+45 \& \\
+75 \mathrm{~min})\end{array}$ & $\begin{array}{l}\text { Between ( } 4 \mathrm{~h} \text { fast }) \\
\text { Between (4 h fast) }\end{array}$ & $\begin{array}{l}- \\
-\end{array}$ & & & & $\begin{array}{l}- \\
-\end{array}$ & & & & & & & & & & \\
\hline Owens \& Benton, 1994 [21] & $96(M=21.2)$ & $50 \mathrm{~g}$ & $\begin{array}{c}\text { Between (No } \\
\text { dietary restriction) }\end{array}$ & & & & & & & & & & & & & & $\mathbf{O}^{3}$ & \\
\hline Craft et al. 1994 [34] & $\begin{array}{l}27(M=20.8) \\
32(M=68.5)\end{array}$ & $\begin{array}{l}50 \mathrm{~g} \\
50 \mathrm{~g}\end{array}$ & $\begin{array}{c}\text { Within } \\
\text { (overnight fast) } \\
\text { Within } \\
\text { (overnight fast) }\end{array}$ & $\begin{array}{l}\mathbf{O}^{3,1} \\
\mathbf{O}^{3,1}\end{array}$ & $\begin{array}{l}- \\
-\end{array}$ & & & & & & $\begin{array}{l}- \\
-\end{array}$ & & $\begin{array}{l}- \\
-\end{array}$ & & $\begin{array}{l}- \\
-\end{array}$ & & & \\
\hline Benton et al., 1994 [35] & $\begin{array}{c}70+50 \\
(M=21.5 \& 21.7)\end{array}$ & $50(+25 \mathrm{~g}$ at $+30 \mathrm{~min})$ & $\begin{array}{c}\text { Between (No } \\
\text { dietary restriction) }\end{array}$ & $\mathrm{O}^{3}$ & & - & & & & & & & - & & & & & \\
\hline Parker \& Benton, 1995 [36] & $100(M=20.15)$ & $50(+25 \mathrm{~g}$ at $+30 \mathrm{~min})$ & $\begin{array}{c}\text { Between (No } \\
\text { dietary restriction) }\end{array}$ & $\mathrm{O}^{2}$ & & & - & & & & & & & & & & & \\
\hline Manning et al., 1997 [31] & $\begin{array}{c}24(M=18.6) \\
23(M=67)\end{array}$ & $\begin{array}{l}50 \mathrm{~g} \\
50 \mathrm{~g}\end{array}$ & $\begin{array}{l}\text { Within (8 h fast) } \\
\text { Within (8 h fast) }\end{array}$ & $\overline{\mathbf{O}}$ & & & $\begin{array}{l}- \\
-\end{array}$ & & & & & & & & $\begin{array}{l}- \\
-\end{array}$ & & & \\
\hline Foster et al., 1998 [7] & $30(\mathrm{M}=19.5)$ & $25 \mathrm{~g}$ & Between (12 h fast) & $\mathrm{O}^{\mathrm{a}}$ & - & & - & - & & & & & & & & & & \\
\hline Messier et al. 1998 [37] & $100(M=21.3)$ & $10 \mathrm{mg} / \mathrm{kg}$ & $\begin{array}{c}\text { Between (No } \\
\text { dietary restriction) }\end{array}$ & - & & & & & & & & & & & & & & \\
\hline
\end{tabular}


Table 2. Cont.

\begin{tabular}{|c|c|c|c|c|c|c|c|c|c|c|c|c|c|c|c|c|c|}
\hline \multirow[b]{2}{*}{ Authors } & \multirow[b]{2}{*}{$\begin{array}{l}\text { Sample Size } \\
\text { (Age) }\end{array}$} & \multirow[b]{2}{*}{$\begin{array}{c}\text { Dose } \\
\text { (Glucose) }\end{array}$} & \multirow[b]{2}{*}{$\begin{array}{c}\text { Design } \\
\text { (Within or } \\
\text { Between Subjects) }\end{array}$} & \multicolumn{14}{|c|}{ Cognitive Outcomes } \\
\hline & & & & 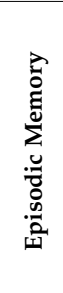 & 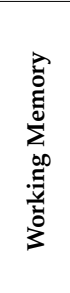 & 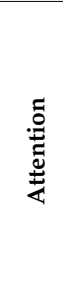 & 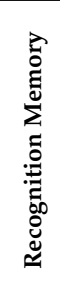 & 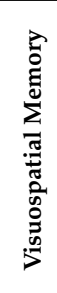 & 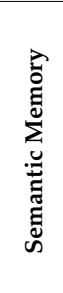 & 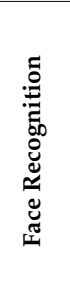 & 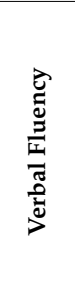 & 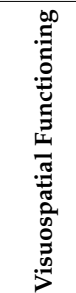 & 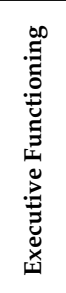 & 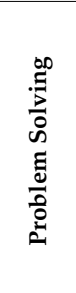 & 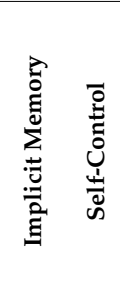 & 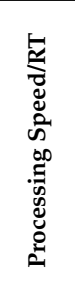 & 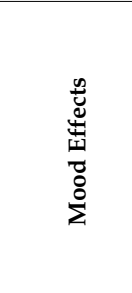 \\
\hline Messier et al. 1998 [37] & $100(M=21.3)$ & $100 \mathrm{mg} / \mathrm{kg}$ & $\begin{array}{c}\text { Between (No } \\
\text { dietary restriction) }\end{array}$ & - & & & & & & & & & & & & & \\
\hline Messier et al. 1998 [37] & $100(M=21.3)$ & $300 \mathrm{mg} / \mathrm{kg}$ & $\begin{array}{c}\text { Between (No } \\
\text { dietary restriction) }\end{array}$ & $\mathrm{O}^{4}$ & & & & & & & & & & & & & \\
\hline Messier et al. 1998 [37] & $100(M=21.3)$ & $500 \mathrm{mg} / \mathrm{kg}$ & $\begin{array}{c}\text { Between (No } \\
\text { dietary restriction) }\end{array}$ & - & & & & & & & & & & & & & \\
\hline Messier et al. 1998 [37] & $100(M=21.3)$ & $800 \mathrm{mg} / \mathrm{kg}$ & $\begin{array}{c}\text { Between (No } \\
\text { dietary restriction) }\end{array}$ & $\mathrm{O}^{4}$ & & & & & & & & & & & & & \\
\hline Messier et al. 1998 [37] & $100(M=21.3)$ & $1000 \mathrm{mg} / \mathrm{kg}$ & $\begin{array}{c}\text { Between (No } \\
\text { dietary restriction) }\end{array}$ & - & & & & & & & & & & & & & \\
\hline Winder \& Borrill, 1998 [32] & $104(M=29.2)$ & $50 \mathrm{~g}$ & $\begin{array}{c}\text { Between (No } \\
\text { dietary restriction) }\end{array}$ & - & & & & & & & & & & & & & - \\
\hline Messier et al. 1999 [38] & $31(M=21.3)$ & $50 \mathrm{~g}$ & $\begin{array}{c}\text { Within } \\
\text { (overnight fast) }\end{array}$ & $\mathbf{O}^{3}$ & & & & & & & & & & & & & \\
\hline Donohoe \& Benton, 1999 [39] & $\begin{array}{c}67+69(M=21.8 \\
\& 20.2)\end{array}$ & $50 \mathrm{~g}$ & $\begin{array}{c}\text { Between (No } \\
\text { dietary restriction) }\end{array}$ & & & & & & & & $\mathbf{O}$ & - & - & & & & \\
\hline Metzger, 2000 [40] & $34(M=21.1)$ & $50 \mathrm{~g}$ & Between (9 h fast) & & & & & & & $\mathbf{O}$ & & & & & & & \\
\hline Kennedy \& Scholey, 2000 [23] & $20(M=20.4)$ & $25 \mathrm{~g}$ & $\begin{array}{c}\text { Within } \\
\text { (overnight fast) }\end{array}$ & & $\mathrm{O}^{\mathrm{b}}$ & & & & & & $-{ }^{b}$ & & & & & & \\
\hline Green et al. 2001 [41] & $26(18-40)$ & $50 \mathrm{~g}$ & Between (8 h fast) & - & & $\mathrm{O}^{5}$ & $\mathbf{O}$ & & & & & & & & & & Vigilance $^{5}$ \\
\hline Morris \& Sarll, 2001 [42] & $80(M=21.2)$ & $50 \mathrm{~g}$ & $\begin{array}{c}\text { Between } \\
\text { (overnight fast) }\end{array}$ & & $\mathrm{O}^{\mathrm{c}}$ & & & & & & & & & & & & \\
\hline Scholey et al. 2001 [43] & $20(M=22.7)$ & $25 \mathrm{~g}$ & $\begin{array}{c}\text { Between } \\
\text { (overnight fast) }\end{array}$ & $-{ }^{b}$ & $\mathrm{O}^{\mathrm{b}}$ & & & & & & $-{ }^{b}$ & & & & & & \\
\hline Mohanty \& Flint, 2001 [19] & $77(M=20.6)$ & $50 \mathrm{~g}$ & $\begin{array}{c}\text { Between } \\
\text { (overnight fast) }\end{array}$ & & & & & & & & & $x^{6}$ & & & & & \\
\hline Mohanty \& Flint, 2001 [19] & $78(M=20.6)$ & $100 \mathrm{mg} / \mathrm{kg}$ & $\begin{array}{c}\text { Between } \\
\text { (overnight fast) }\end{array}$ & & & & & & & & & $O x^{6}$ & & & & & \\
\hline
\end{tabular}


Table 2. Cont

\begin{tabular}{|c|c|c|c|c|c|c|c|c|c|c|c|c|c|c|c|c|c|c|}
\hline \multirow[b]{2}{*}{ Authors } & \multirow[b]{2}{*}{$\begin{array}{l}\text { Sample Size } \\
\text { (Age) }\end{array}$} & \multirow[b]{2}{*}{$\begin{array}{c}\text { Dose } \\
\text { (Glucose) }\end{array}$} & \multirow[b]{2}{*}{$\begin{array}{c}\text { Design } \\
\text { (Within or } \\
\text { Between Subjects) }\end{array}$} & \multicolumn{15}{|c|}{ Cognitive Outcomes } \\
\hline & & & & 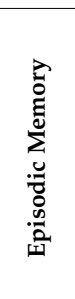 & 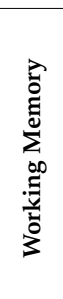 & 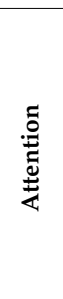 & 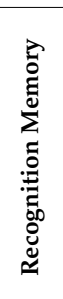 & 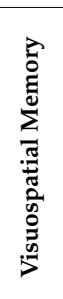 & 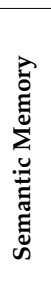 & 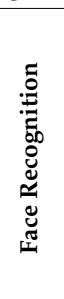 & 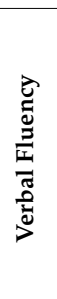 & 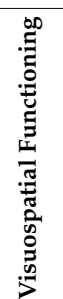 & 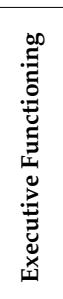 & 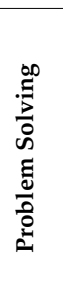 & 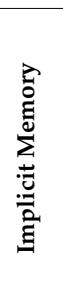 & 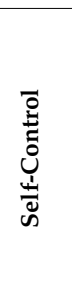 & 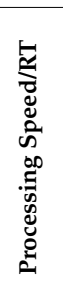 & 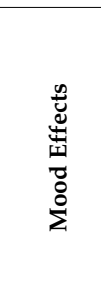 \\
\hline Sunram-Lea et al. 2001 [17] & $60(18-28)$ & $25 \mathrm{~g}$ & $\begin{array}{l}\text { Between (overnight } \\
\text { fast vs. breakfast } \\
\text { vs. lunch) }\end{array}$ & $\mathbf{O}^{\mathrm{a}}$ & - & & $\mathbf{O}^{\mathrm{a}}$ & $\mathbf{O}^{\text {a }}$ & & & & & & & & & & \\
\hline Awad et al, 2002 [44] & $74(M=21)$ & $75 \mathrm{~g}$ & $\begin{array}{c}\text { Between } \\
\text { (overnight fast) }\end{array}$ & $\mathbf{O}^{\mathrm{a}, \mathrm{b}}$ & & & & & & & & & & & & & & \\
\hline Scholey \& Fowles, 2002 [20] & $35(M=23.6)$ & $25 \mathrm{~g}$ & $\begin{array}{c}\text { Between (No } \\
\text { dietary restriction) }\end{array}$ & & & & & & & & & O & & & & & & - \\
\hline Sunram-Lea et al. 2011 [16] & $60(M=21)$ & $25 \mathrm{~g}$ & Between ( $2 \mathrm{~h}$ fast) & $\mathrm{O}$ & - & & $\mathbf{O}$ & $\mathrm{O}$ & & & & & & & & & & - \\
\hline Sunram-Lea et al. 2002a [18] & $80(M=20)$ & $25 \mathrm{~g}$ & Between ( $2 \mathrm{~h}$ fast $)$ & $\mathrm{O}^{\mathrm{a}}$ & $\mathrm{O}^{\mathrm{a}}$ & & $\mathbf{O}^{\mathrm{a}}$ & $\mathrm{O}^{\mathrm{a}}$ & & & & & & & & & & - \\
\hline Ford et al. 2002 [45] & $20(20-23)$ & $25 \mathrm{~g}$ & $\begin{array}{c}\text { Within } \\
\text { (overnight fast) }\end{array}$ & $-{ }^{6}$ & & & $-{ }^{6}$ & & & & & & & & & & & \\
\hline Flint \& Turek, 2003 [46] & $67(M=19.49)$ & $10 \mathrm{mg} / \mathrm{kg}$ & Between ( $8 \mathrm{~h}$ fast) & & & - & & & & & & & & & & & & \\
\hline Flint \& Turek, 2003 [46] & $67(M=19.49)$ & $100 \mathrm{mg} / \mathrm{kg}$ & Between (8 h fast) & & & $x$ & & & & & & & & & & & & \\
\hline Flint \& Turek, 2003 [46] & $67(M=19.49)$ & $500 \mathrm{mg} / \mathrm{kg}$ & Between ( $8 \mathrm{~h}$ fast) & & & - & & & & & & & & & & & & \\
\hline Flint \& Turek, 2003 [46] & $67(M=19.49)$ & $50 \mathrm{~g}$ & Between (8 h fast) & & & - & & & & & & & & & & & & \\
\hline Meikle et al. $2004^{3}$ [26] & $14(M=21.8)$ & $25 \mathrm{~g}$ & $\begin{array}{c}\text { Within } \\
\text { (overnight fast) }\end{array}$ & o & - & - & & & & & - & - & - & & & & & \\
\hline Meikle et al. $2004^{3}$ [26] & $14(M=21.8)$ & $50 \mathrm{~g}$ & $\begin{array}{c}\text { Within } \\
\text { (overnight fast) }\end{array}$ & $\mathrm{O}$ & - & - & & & & & - & - & - & & & & & \\
\hline Meikle et al. $2004^{3}$ [26] & $11(M=38.4)$ & $25 \mathrm{~g}$ & $\begin{array}{c}\text { Within } \\
\text { (overnight fast) }\end{array}$ & $\mathbf{O}^{\mathrm{b}}$ & O & $\mathrm{O}$ & & & & & - & - & - & & & & & \\
\hline Meikle et al. $2004^{3}$ [26] & $11(M=38.4)$ & $50 \mathrm{~g}$ & $\begin{array}{c}\text { Within } \\
\text { (overnight fast) }\end{array}$ & $\mathbf{O}^{\mathrm{b}}$ & o & $\mathrm{O}$ & & & & & - & - & - & & & & & \\
\hline Meikle et al. 2005 [47] & $\begin{array}{c}37+24 \\
(M=28.5 \& 18.9)\end{array}$ & $25 \mathrm{~g}$ & $\begin{array}{c}\text { Between } \\
\text { (overnight fast) }\end{array}$ & $\mathrm{O}^{\mathrm{b}}$ & & & & & & & & & & & & & & \\
\hline Reay et al. 2006 [27] & $27(M=21.9)$ & $25 \mathrm{~g}$ & $\begin{array}{c}\text { Within } \\
\text { (overnight fast) }\end{array}$ & & $\mathrm{O}^{\mathrm{b}}$ & $\mathrm{O}^{\mathrm{b}}$ & & & & & & & & & & & & $\begin{array}{l}\text { Mental } \\
\text { Fatigue }\end{array}$ \\
\hline
\end{tabular}


Table 2. Cont

\begin{tabular}{|c|c|c|c|c|c|c|c|c|c|c|c|c|c|c|c|c|c|c|}
\hline \multirow[b]{2}{*}{ Authors } & \multirow[b]{2}{*}{$\begin{array}{l}\text { Sample Size } \\
\text { (Age) }\end{array}$} & \multirow[b]{2}{*}{$\begin{array}{c}\text { Dose } \\
\text { (Glucose) }\end{array}$} & \multirow[b]{2}{*}{$\begin{array}{c}\text { Design } \\
\text { (Within or } \\
\text { Between Subjects) }\end{array}$} & \multicolumn{15}{|c|}{ Cognitive Outcomes } \\
\hline & & & & 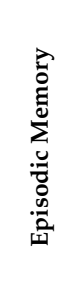 & 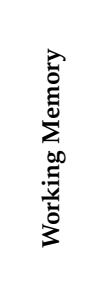 & 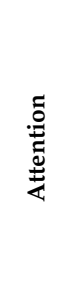 & 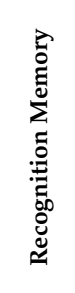 & 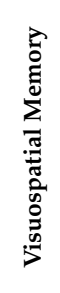 & 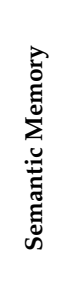 & 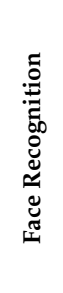 & 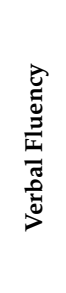 & 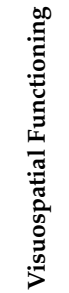 & 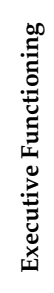 & 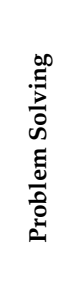 & 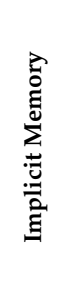 & 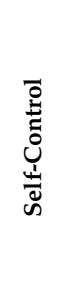 & 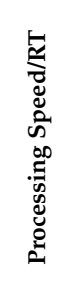 & 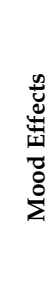 \\
\hline Riby et al. 2006 [48] & $14(M=30.1)$ & $25 \mathrm{~g}$ & $\begin{array}{c}\text { Within } \\
\text { (overnight fast) }\end{array}$ & $\mathbf{O}^{\mathrm{a}}$ & & & & & $\mathbf{O}^{\mathrm{a}}$ & & $-{ }^{a}$ & & & & & & & \\
\hline Brandt et al. 2006 [49] & $40(M=22)$ & $25 \mathrm{~g}$ & Between ( $2 \mathrm{~h}$ fast $)$ & & & & $-{ }^{6}$ & & & & & & & & & & & \\
\hline Gailliot et al. 2007 [50] & $62+73+18$ & Not stated & Between & & & & & & & & & & & & & $\mathrm{O}$ & & \\
\hline $\begin{array}{c}\text { Masicampo \& Baumeister, } \\
2008[51]\end{array}$ & 121 & Not stated & Between & & & & & & & & & & & & & $\mathrm{O}$ & & \\
\hline DeWall et al. 2008 [52] & 37 & Not stated & Between & & & & & & & & & & & & & $\mathrm{O}$ & & \\
\hline Morris, 2008 [53] & $72(M=22.4)$ & $50 \mathrm{~g}$ & $\begin{array}{c}\text { Between (No } \\
\text { dietary restriction) }\end{array}$ & o & & & & & & & & & - & & & & & \\
\hline Riby et al. 2008 [54] & $33(35-55)$ & $25 \mathrm{~g}$ & Within (2 h fast) & - & - & & & & & & & & & & & & & \\
\hline Riby et al. 2008 [54] & $33(35-55)$ & $50 \mathrm{~g}$ & Within (2 h fast) & $\mathbf{O}$ & - & & & & & & & & - & & & & & \\
\hline Sunram-Lea et al. 2008 [14] & $56(M=20)$ & $25 \mathrm{~g}$ & Between ( $2 \mathrm{~h}$ fast $)$ & & & & $\mathrm{O}$ & & & & & & & & & & & \\
\hline Scholey \& Kennedy, 2009 [55] & $120(M=21.6)$ & $25 \mathrm{~g}$ & $\begin{array}{c}\text { Between } \\
\text { (overnight fast) }\end{array}$ & $-{ }^{a}$ & & $\mathrm{O}^{\mathrm{a}}$ & & & & & & & & & & & & \\
\hline Scholey et al. 2009 [56] & $120(M=21.6)$ & $25 \mathrm{~g}$ & $\begin{array}{c}\text { Within } \\
\text { (overnight fast) }\end{array}$ & $\mathbf{O}^{7}$ & & $\mathrm{O}^{\mathrm{a}}$ & $-{ }^{a}$ & & & & & & & & & & & \\
\hline Owen et al. 2010 [57] & $90(M=21)$ & $25 \mathrm{~g}$ & Between (12 h fast) & - & & & - & & & - & & & & & - & & & \\
\hline Owen et al. 2010 [57] & $90(M=21)$ & $60 \mathrm{~g}$ & Between (12 h fast) & $\mathrm{O}$ & & & 0 & & & - & & & & & O & & & \\
\hline Brandt et al, 2010 [58] & $40(M=19.1)$ & $15 \mathrm{~g}$ & Between ( $2 \mathrm{~h}$ fast $)$ & & & & $-{ }^{6}$ & & & & & & & & & & & \\
\hline Brandt et al, 2010 [58] & $40(M=21)$ & $25 \mathrm{~g}$ & Between (2 h fast) & & & & $-6, \mathrm{~b}$ & & & & & & & & & & & \\
\hline Parent et al. 2011 [59] & $14(M=21.4)$ & $50 \mathrm{~g}$ & Within & $\mathbf{O}^{8}$ & & & & & & & & & & & & & & \\
\hline Smith et al. 2011 [60] & $40(M=15.5)$ & $25 \mathrm{~g}$ & $\begin{array}{c}\text { Between } \\
\text { (overnight fast) }\end{array}$ & $\mathbf{O}^{9, \mathrm{~b}}$ & & & & & & & & & & & & & & - \\
\hline Sunram-Lea et al. 2011 [16] & $30(M=20)$ & $15 \mathrm{~g}$ & Between (12 h fast) & - & - & & - & & & & & & & & & & & \\
\hline Sunram-Lea et al. 2011 [16] & $30(M=20)$ & $25 \mathrm{~g}$ & Between (12 h fast) & $\mathrm{O}$ & $-\mathbf{O}^{10}$ & & 0 & & & & & & & & & & & \\
\hline Sunram-Lea et al. 2011 [16] & $30(M=20)$ & $50 \mathrm{~g}$ & Between (12 h fast) & - & - & & - & & & & & & & & & & & \\
\hline
\end{tabular}


Table 2. Cont.

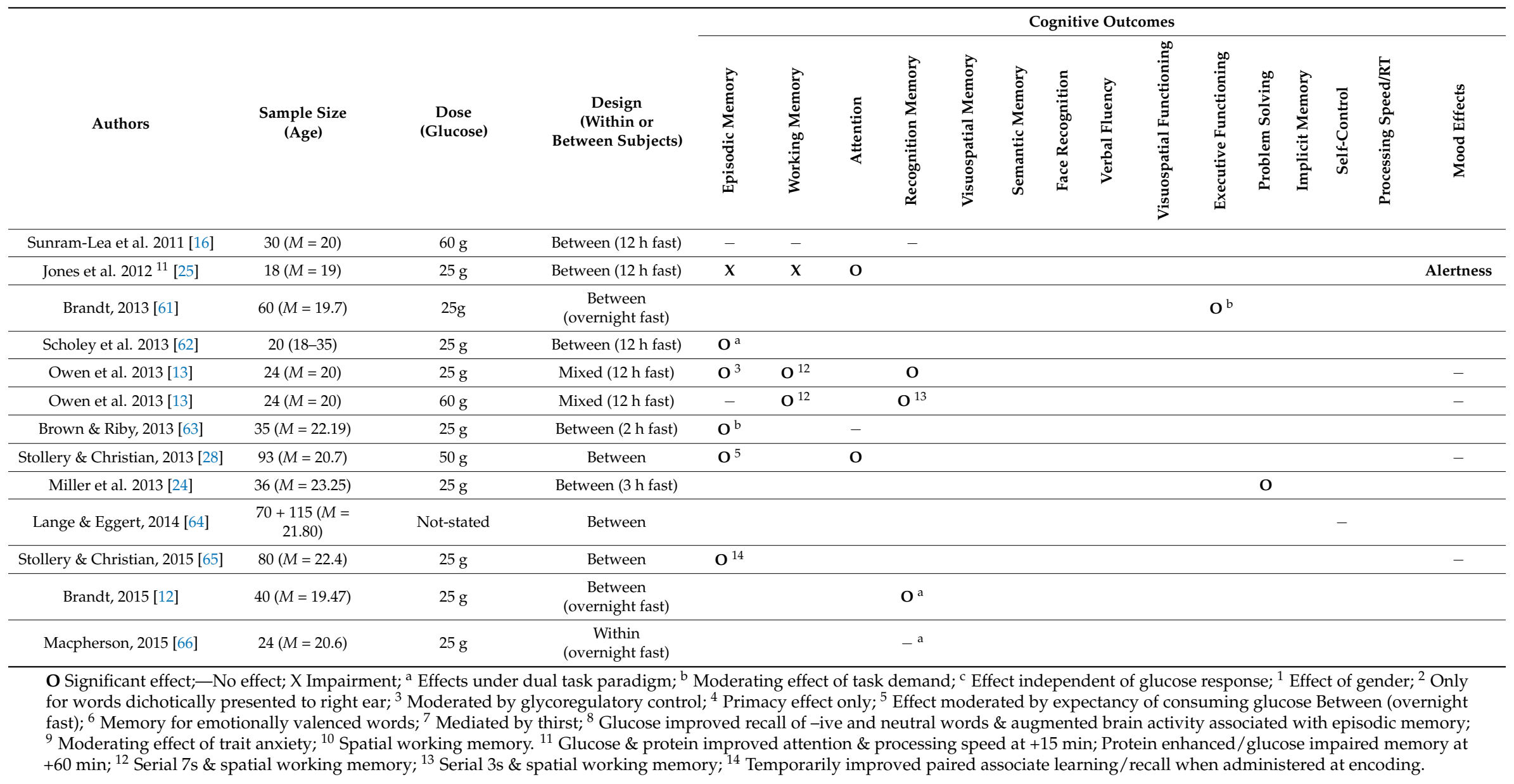




\subsubsection{The Effect of Dose}

The majority of studies have administered an acute $25 \mathrm{~g}$ glucose dose. This is often cited as the optimum dosage for the facilitative effect of glucose on memory [9]. This dose also provokes a human blood glucose increase commensurate with the blood glucose levels shown to have facilitative cognitive effects in rats (100 mg/kg [67]). An inverted U-shaped dose response curve between glucose dose and memory performance has been demonstrated in animal models [68-70]. There is also evidence to suggest this relationship may be bimodal with performance peaks at $100 \mathrm{mg} / \mathrm{kg}$ and $2000 \mathrm{mg} / \mathrm{kg}$ [71]. Evidence from clinical populations (e.g., diabetic samples) demonstrate impaired performance associated with hypo- and hyperglycemia [72]. Support for an inverted U-shape relationship has been demonstrated in elderly humans [73]. A limited number of studies have systematically examined the dose response relationship in young healthy samples. Azari et al. [29] found no effects of 0,30 or $100 \mathrm{~g}$ of glucose on episodic or recognition memory $\left(M_{\text {age }}=21\right.$ years $)$. Meikle et al. [26] administered 0, 25 and $50 \mathrm{~g}$ of glucose to young $\left(M_{\text {age }}=21.8\right.$ years $)$ and middle-aged $\left(M_{\text {age }}=38.4\right.$ years $)$ samples. Episodic memory was generally enhanced by glucose intake $(25 \mathrm{~g}$ and $50 \mathrm{~g}$ ) with evidence of greater facilitation of performance in the middle-aged sample. Messier et al. [37] administered a broader range of acute doses $(0,100,300,500,800$, and $1000 \mathrm{mg} / \mathrm{kg}$ of body weight) to examine the dose-response curve of the effect of glucose on episodic memory ( $M_{\text {age }}=21.3$ years). The $300 \mathrm{mg} / \mathrm{kg}$ and $800 \mathrm{mg} / \mathrm{kg}$ doses resulted in attenuation of the commonly observed decline in the primacy effect (enhanced recall of information presented first) as respondents learnt an increasing number of word lists. This suggests a bimodal relationship between glucose dose and facilitation $(10 \mathrm{mg} / \mathrm{kg}, 100 \mathrm{mg} / \mathrm{kg}, 500 \mathrm{mg} / \mathrm{kg}$ and $1000 \mathrm{mg} / \mathrm{kg}$ did not facilitate performance). Sünram-Lea et al. [16] examined episodic memory recall and recognition and working memory after administration of 15, 25, 50, and $60 \mathrm{~g}$ glucose loads $\left(M_{\text {age }}=20\right.$ years). Facilitation of spatial working memory, immediate and delayed recall, and recognition were reported for the $25 \mathrm{~g}$ glucose dose. No facilitative effects were demonstrated at lower $(15 \mathrm{~g})$ or higher $(50 \mathrm{~g}$ and $60 \mathrm{~g})$ doses. This supports the proposition of a specific optimal glucose dose of $25 \mathrm{~g}$. However, divergent dose response curves were evident dependent upon cognitive domain. An inverted U-shape dose response profile was largely demonstrated for episodic memory performance. However, performance did not fall below control levels at high doses as would be predicted by an inverted $U$ curve. The dose-response relationship of working memory performance adhered to a cubic trend characterized by facilitation at the lowest and highest doses. Spatial working memory enhancement was significant at $25 \mathrm{~g}$ but additional enhancement trends were observed at higher doses, suggestive of a quartic trend [16].

The current data suggests the facilitative glucose dose-response relationship is complex and may be domain specific. Whilst there is some support for the proposition that $25 \mathrm{~g}$ is optimal for facilitative effects on memory performance, this evidence is primarily representative of the enhancing effects on episodic memory; specifically, delayed, verbal episodic memory [74]. However, a number of studies have failed to demonstrate facilitative effects of a $25 \mathrm{~g}$ dose. Enhanced performance has also been demonstrated after lower $(15 \mathrm{~g})$ and higher $(50,60$ and $75 \mathrm{~g})$ doses. If the facilitative effect of glucose followed an inverted U-shaped dose response curve, impaired performance should be demonstrated at very low and high doses. There is little evidence to support this proposition in the limited number of dose response studies that have been undertaken in healthy young samples. Flint and Turek [46] reported impaired attention performance after $100 \mathrm{mg} / \mathrm{kg}$ glucose drink. However, $500 \mathrm{mg} / \mathrm{kg}$ did not impair performance. This finding contradicts impairment as a function of increasing dose.

\subsubsection{The Effect of Age}

Reduced glucose control $[44,75]$ and dysregulation of neuroendocrine processes associated with cognitive function and glucose regulation (e.g., adrenaline [76]) are common corollaries of ageing. Cognitive capacity also diminishes as a function of age resulting in a tendency for poorer performance on cognitive tasks in older vs. younger adults [77]. The combination of a compromised glucoregulatory system and deficits in cognitive function may result in an increased sensitivity to the facilitative effects 
of glucose in older adults. Indeed, differential effects of glucose administration in older samples are evident. Hall et al. [22] reported greater enhanced episodic memory after $50 \mathrm{~g}$ of glucose in elderly $\left(M_{\text {age }}=67.4\right)$ vs. young $\left(M_{\text {age }}=20\right)$ adults. Working memory performance was also selectively enhanced only in the young. Further, individual glucose tolerance predicted memory performance in the elderly only (effects of glucoregulatory control discussed in Section 2.2.4).

Meikle et al. [26] highlighted the importance of task demand on the relationship between glucose facilitation and age. The level of task demand moderated the degree of glucose enhancement of short-term episodic memory in middle-aged $\left(M_{\text {age }}=38.4\right)$ vs. young $\left(M_{\text {age }}=21.8\right)$ adults. Glucose intake ( $25 \mathrm{~g}$ and $50 \mathrm{~g}$ ) restored middle-aged adults' memory performance to that of their young counterparts only on higher cognitive load trials. This selective facilitative effect may be indicative of the capacity of glucose to offer greater benefit to those that are not performing close to ceiling. Young, healthy adults may be operating near the limit of cognitive capacity, leaving little room for performance improvement. Conversely, age-related cognitive decline in middle-aged adults may result in cognitive deficits under higher cognitive loads which may be sensitive to glucose facilitation.

\subsubsection{The Effect of Task Demand}

A number of studies have failed to demonstrate glucose enhancement in healthy young adults when episodic memory was assessed under single task conditions (e.g., [29,31,33,57]). Studies that do report facilitative effects under single task conditions often demonstrate primacy and recency effects [35,37]. Tasks that place a high demand on cognitive resources, or performance assessed under dual/multi-task demands, appear more sensitive to the facilitative effects of glucose (e.g., $[7,15,27,35,36,48])$. These studies suggest glucose may preferentially facilitate tasks that require a high cognitive processing load.

The dual task paradigm (the performance of two concurrent or consecutive tasks to increase distraction or cognitive load) has been commonly employed to demonstrate the effects of cognitive load on the relationship between glucose and cognitive performance. For example, Sünram-Lea et al. [15] reported episodic memory enhancement only when participants were concurrently performing an additional task. Similar glucose enhancement under conditions of divided attention have been reported $[7,48,55]$. The level of task demand also appears to moderate the glucose facilitation effect. Cognitive tasks that are more cognitively demanding may be particularly sensitive to glucose loading. Brown and Riby [63] demonstrated glucose facilitation only for the most demanding episodic memory and attention task conditions. Glucose results in greater performance enhancement on incongruent, thus more difficult, trials in the Stroop task paradigm [61]. Preferential enhancement of recall of low imagery word pairs and longer words lists has also been reported [47]. Related to increased cognitive demand, Reay et al. [27] suggest the facilitative effect of glucose may only appear as fatigue increases when faced with demanding, prolonged tasks.

The mediating role of task demand and load is underpinned by the assumption that cognitive capacity and/or glucose resources are 'depleted' by the excessive demands placed upon them. The energy requirements of the brain are substantial, approximately $20 \%-30 \%$ of an organism's basal metabolic output [78]. The brain has long been considered to lack storage capacity for energy substrates and is therefore reliant upon the aerobic degradation of glucose and oxygen supplied in the bloodstream [43]. Some have argued that the metabolic energy cost of effortful, controlled or executive cognitive processes are higher than the cost of automatic or reflexive processes [50]. Therefore, cognitively demanding tasks may consume more glucose and may be more sensitive to manipulations of peripheral blood glucose. Animal models have demonstrated selective reduction of extracellular glucose concentration in the hippocampus mediated by the level of cognitive demand [79]. There is limited evidence of lowered peripheral glucose levels associated with performance on demanding cognitive tasks in humans $[43,80,81]$. Authors have inferred a directional effect, assuming that that more demand leads to lower peripheral glucose.

The cognitive act of self-control is one cognitive domain that has been proposed to demonstrate the specific effects of depleted cognitive capacity at high demands, and the direct restorative effects 
of glucose intake. Acts of self-control require the effortful inhibition of predominant responses, emotions, thoughts, and impulses, permitting behavior to vary adaptively moment to moment $[82,83]$. The strength model of self-control asserts that self-control is a uniquely demanding domain of cognition, and self-control tasks deplete a limited cognitive resource resulting in reduced subsequent self-control performance; a state of 'ego-depletion'. Gailliot and Baumeister [50] proposed that glucose is the direct central energy source of self-control. This proposition was founded on evidence of: (i) reduced blood glucose levels after initial exertion of self-control; (ii) an association between subsequent, post-depletion, self-control performance and blood glucose decline; and (iii) attenuation of the detrimental ego depletion effect on self-control performance after ingestion of glucose, but not artificial sweetener [81].

The capacity of glucose ingestion to counteract the impairing effect of ego depletion has been demonstrated (e.g., $[51,52,81])$. However, these studies provide scant information as regards glucose dose, sample composition, and the methods of depleting and measuring self-control performance often appear arbitrary (e.g., writing about one's death [81]). Moreover, the precise role of glucose in self-control performance remains indistinct. Firstly, a number of studies have demonstrated that glucose can influence performance on self-control tasks in a non-energetic manner. Merely sensing carbohydrates, but not artificial sweeteners, in the oral cavity can confer a restorative benefit on cognitive self-control performance under conditions of ego-depletion [84-86]. The positive effect of carbohydrate oral rinsing has also been demonstrated in physical endurance performance $[87,88]$, conferring greater performance benefits than ingestion [89]. Such findings suggest a potential motivational rather than metabolic effect of carbohydrates on performance, underpinned by activation of motivational neural reward pathways [88,90,91].

It is important to note that evidence of lowered peripheral blood glucose related to the level of cognitive demand is weak. Fairclough and Houston [80] and Scholey et al. [43] reported a peripheral decrease in capillary blood glucose $<1 \mathrm{mmol} / \mathrm{L}$. Both studies employed commercially available fingerprick based capillary blood glucose analyzer devices to measure glucose levels in a healthy sample. These devices are not designed to accurately detect blood glucose excursions outside the euglycemic range. Such effects should therefore be treated with caution. Subsequent attempts to replicate the moderation of peripheral blood glucose by exertion of self-control have also not supported the finding that demanding tasks consume more glucose [91]. Indeed, our laboratory recently failed to find any moderation of capillary blood or interstitial glucose by self-control exertion, rigorously assessed using formal laboratory standard capillary blood glucose analysis techniques and continuous interstitial glucose monitoring [92].

Regulation of glucose transport across the blood brain barrier (BBB) occurs via GLUT1 transporters but this process is not well understood [93]. Glucose levels in the brain are approximately $30 \%$ of those in peripheral blood [94]. Long term elevations in peripheral glucose result in decreased glucose transport across the BBB [95]. During brain activation, utilization and local concentrations of glucose have been shown to alter. An increase in glucose uptake by the brain in young males undertaking a complex visuo-spatial motor task was observed in a PET study [96], and in rats, a decrease in hippocampal interstitial glucose levels proportional to the difficulty of the maze was observed [79]. However, in both studies peripheral glucose concentrations remained unchanged. This suggests that cognitive demand will be accompanied by increased local glucose metabolism in those brain areas engaged in specific tasks. Moreover, the amount of glucose required for acts of self-control and cognitively demanding tasks is likely to be negligible in absolute brain energy cost terms. Furthermore, reduced peripheral glucose by cognitive demand is unlikely considering the efficiency of homeostatic systems in maintaining brain energy levels [85]. Behavioral evidence for an effect of task demand is also mixed. Facilitative glucose effects on lower (serial 3's), but not higher (serial 7's) demand tasks [13], and no effects of dual task demand [66] have been demonstrated. This is counter to what would be expected if glucose uptake changed in response to demand. 


\subsubsection{The Effect of Glucoregulatory Control}

Glucose regulation appears to be a key moderator of optimal cognition functioning. Hypoglycemia, induced experimentally, or in type 1 diabetes, is associated with impaired cognitive performance $[97,98]$. Further, poor glycemic control in type 2 diabetes is associated with impaired memory [99], and increased risk of cognitive decline [100]. Impaired glucose tolerance (IGT), which is associated with insulin insensitivity and is increasingly prevalent in the general population due to the increased incidence of obesity, also affects cognitive function [101]. Intranasal insulin and thiazolidinediones (which improve insulin sensitivity) improve memory function. This effect is linked to lowered blood glucose concentrations rather than altered insulin levels [102].

The literature suggests that the facilitative effects of glucose on cognitive performance may be moderated by an individual's ability to regulate their blood glucose response. Therefore, whilst it is commonly stated that a $25 \mathrm{~g}$ glucose dose is optimal for facilitative effects, the failure of the majority of studies to take into account the mediating effects of glucoregulatory control, and factors associated with the regulation of glucose (e.g., age, weight, BMI), may account for some heterogeneity in the evidence.

The variable effects of glucose regulation have been shown as a function of glucoregulatory control and age. For example, performance deficits in an elderly sample demonstrated after intake of $50 \mathrm{~g}$ of glucose were partly moderated by differences in glucose regulation [73]. Craft et al. [34] demonstrated that performance on a verbal episodic memory task was differentially affected dependent upon glucose regulation in elderly $\left(M_{\text {age }}=68.5\right)$ vs. young $\left(M_{\text {age }}=20.8\right)$ adults. Elderly performance was enhanced in good, and impaired in poor, glucose regulators (indexed by degree to which blood glucose returned to baseline levels). Conversely, younger adults showed the opposite response pattern: prolonged elevated blood glucose levels were associated with enhanced performance and good regulatory control was associated with impaired performance.

The effects of glucoregulation in studies of exclusively young, healthy samples are mixed, with evidence of selective effects in individuals with poor or good glucoregulatory control. Evidence of selective facilitative effects in those with poor regulatory control [13,38], but no effects [44], or impairment [57] in those with better regulatory control has been reported. Conversely, individuals with better glucoregulatory control have been shown to be particularly sensitive to the facilitative effects of glucose (e.g., [26]). Sünram-Lea et al. [16] also reported tentative (due to doubts about the methodology adopted to classify poor and good glucose regulation) facilitative effects of higher glucose loads in good glucose regulators. This study also highlighted the moderating effect of weight and body composition. The data suggested that individuals with low and medium BMI $\left(<25 \mathrm{~kg} / \mathrm{m}^{2}\right)$ show facilitative effects of high acute glucose loads, whilst higher BMI $\left(>25 \mathrm{~kg} / \mathrm{m}^{2}\right)$ was associated with performance decrements. Poorer glucose regulation is demonstrated in the overweight and obese, however, no direct evidence of BMI moderating glycemic response to a glucose load was reported in this study. Body mass index was positively associated with basal fasted glucose levels suggesting this effect may be mediated by the long-term action of insulin resistance more evident in overweight and obese individuals.

\subsubsection{Emotional Valence}

Emotionally laden stimuli (e.g., words, pictures) are more memorable than neutral stimuli; the 'emotional enhancement effect' [103]. This effect has been demonstrated across a number of cognitive domains, but predominantly recognition and recall. The effect is likely underpinned by the acute emotional arousal activating the release of glucocorticoids and adrenaline. A major physiological role of both of these hormones is to temporarily increase energy production, specifically the provision of increased metabolic fuel via increased glucose availability [58]. There is some modest evidence that exposure to emotionally valenced words can raise plasma glucose levels $[104,105]$. This suggests memory for emotionally valenced stimuli may be particularly sensitive to acute glucose manipulations. A number of studies have examined the potential for glucose to moderate the emotional enhancement effect. However, the findings to date are mixed. Both $50 \mathrm{~g}$ and $100 \mathrm{mg} / \mathrm{kg}$ impaired emotionally 
valenced spatial memory performance [19]; $50 \mathrm{~g}$ glucose enhanced performance for neutral trials. Further studies have demonstrated no additional effect above the standard emotional enhancement effect of $25 \mathrm{~g}$ of glucose [45,49]. Brandt et al. [58] proposed the mixed findings may be a dosing problem. Whilst 25-50 g may be sufficient for the enhancement of neutral stimuli, commonly adopted in studies of episodic memory, a lower dose may be optimal for the enhancement of emotional stimuli as blood glucose levels may already have been augmented by mere exposure to the arousing stimuli. However, only a marginal effect of a $15 \mathrm{~g}$ glucose dose on recognition memory was observed. This suggests glucose administration does not affect the memory advantage evident for emotional stimuli. It is likely that an independent relationship exists between blood glucose levels and memory of emotional material.

\subsubsection{Expectancy Effects}

The capacity of merely sensing glucose in the oral cavity to enhance cognitive performance raises the possibility of potential non-metabolic facilitative effects of glucose. Support for this proposition comes from studies demonstrating the crucial moderating factor of the expectancy of consuming glucose. Expectations relating to the effects of caffeine and alcohol intake have been shown to moderate cognitive performance [106]. Similar effects may be expected for the consumption of glucose. Indeed, comparing participants who were correctly or incorrectly informed of the content of a drink, Green et al. [41] demonstrated improved vigilance performance only when respondents were given a drink congruent message (i.e., glucose intake with expectancy of intake). However, Stollery and Christian [28] suggest the effects of expectancy beliefs for glucose may be modest and relatively isolated to internal indices of specific cognitive tasks. For example, inducing within-task trade-offs, for example, recall of more high imageability words vs. low imageability words if expecting glucose, without any tangible effect on overall performance (i.e., number of words recalled). Therefore, the authors suggest expectancy effects are unlikely to be confused with glucose enhancement effects. However, the potential for expectancy effects to augment specific domains of performance [41], or change the nature of performance within specific domains [28], suggests data on participant expectations should be collected.

A related effect is the mediating impact of thirst on glucose facilitation. Scholey et al. [56] reported participants who self-reported being less thirsty at baseline recalled significantly more, and those thirstier significantly fewer, words after glucose intake vs placebo. However, no further attempt has been made to corroborate this finding. The potential mediating roles of subjective expectancy and thirst on the enhancing potential of glucose are worthy of further examination.

\subsection{Glucose and Subjective Mood}

There is increasing interest in the capacity for glucose to enhance subjective mood. A number of studies examining the effects of glucose on cognitive performance additionally measured participants' subjective ratings of alertness, energy, and fatigue. Such measures were considered to index the perceived level of arousal following glucose intake. Recently, 'mental energy' has been proposed as a construct that can be employed to define the facilitative effects of macronutrient intervention on subjective arousal [107]. Mental energy is defined "as the ability to perform mental tasks, the intensity of feelings of energy and fatigue, and the motivation to accomplish mental and physical tasks" (p. 697 [107]). This construct comprises three dimensions: mood (transient feeling related to energy / fatigue levels), motivation (subjective determination and enthusiasm), and cognition (sustained attention and vigilance).

The facilitative effect of glucose on sustained attention and vigilance has been demonstrated (e.g., $[13,25-27,55])$, but not consistently [26,28,35,46]. However, there is little evidence to support the facilitative effects of glucose intake on the mood and motivation dimensions of mental energy. Reay et al. [27] reported reduced mental fatigue towards the end of a cognitively demanding test battery after a $25 \mathrm{~g}$ glucose load. A $50 \mathrm{~g}$ glucose load increased subjective vigilance ratings $30 \mathrm{~min}$ after intake [41]. However, this was only demonstrated when participants were informed that they 
were consuming glucose, suggesting an expectancy, rather than metabolic, effect of energy intake. Scholey et al. [55] demonstrated that alertness ratings increased significantly after consumption of both a $25 \mathrm{~g}$ glucose and placebo drink contradicting any specific enhancing mood effect of glucose intake. No studies have specifically measured motivational state in relation to cognitive performance after glucose intake. Therefore, the evidence to date does not support the specific subjective mood enhancing effects of glucose intake.

\subsection{Other Carbohydrates and Cognitive Function}

\subsubsection{Fructose}

Fructose, commonly known as fruit sugar, is a simple ketonic monosaccharide. The metabolic response profile of fructose is markedly different to that of glucose. Fructose does not significantly affect blood glucose levels, is not actively transported across the BBB, nor does it provide direct energy for cellular processes [24]. Such factors likely explain the comparative lack of research examining the effects of fructose on cognition. The available human evidence has shown facilitative effects on problem solving performance comparable to that of glucose intake (Table 3 [24]). Therefore, facilitation was evident in the presence and absence of a blood glucose response. A number of studies have highlighted that oral sensing of $\mathrm{CHO}$ alone is sufficient to enhance performance (e.g., [108]). This suggests a motivational, rather than metabolic, effect of $\mathrm{CHO}$ on performance via activation of neural reward pathways [88,91,109]. However, fructose and glucose differ in their capacity to activate motivational reward pathways; glucose activates, fructose inhibits, cortical responding [110]. Miller et al. [24] suggest activation of motivational reward pathways may not be necessary for performance facilitation. The facilitative effects of glucose and fructose may be due to activation of peripheral glucose-transport mechanisms or innervations of the vagus nerve. Increased vagus nerve activation and vagal tone have been associated with enhanced cognitive performance (e.g., [111]). However, such explanations have yet to be verified. Further, the facilitative effects of glucose may act via multiple pathways, including metabolic and peripheral mechanisms.

\subsubsection{Sucrose}

Sucrose is a plant-derived disaccharide composed of glucose and fructose linked by an ether bond. Sucrose has the potential to affect neural function both directly, via glucose, and by indirect peripheral mechanisms, via fructose. Early studies examining the effects of sucrose in young children demonstrated no facilitative effects on cognitive performance [112,113]. A limited number of studies have directly examined the effect of sucrose on cognitive performance in adults. Attention and information processing were enhanced by $100 \mathrm{~g}$ of sucrose, but not $50 \mathrm{~g}$ glucose, in an elderly sample with mild memory complaints [114]. Sucrose may therefore proffer additional facilitative benefits to cognitive performance compared to glucose alone. Gailliot et al. [108] reported that self-control performance (suppression of homosexual stereotypes during a writing task) was bolstered by intake of a sucrose containing drink. However, very little methodological detail is provided for this study, including sucrose dose. Harte and Kanarek [115] examined the interactive effects of nicotine and sucrose intake on attention and spatial memory. Nicotine gum combined with a sucrose drink interacted to facilitate sustained attention performance compared to nicotine and an aspartame drink. Further, the sucrose drink in isolation enhanced spatial memory performance vs. the placebo. This demonstrates both the facilitative effect of sucrose and additive effects on performance when combined with nicotine. However, an enhancing effect of sucrose has not been consistently demonstrated. For example, Dye et al. [116] reported no effects of sucrose on episodic and working memory, or psychomotor function. 
Table 3. Summary of studies examining the effects of fructose, sucrose and isomaltulose on cognitive performance domains.

\begin{tabular}{|c|c|c|c|c|c|c|c|c|c|c|c|c|c|c|c|c|}
\hline \multirow[b]{2}{*}{ CHO Source } & \multirow[b]{2}{*}{ Authors } & \multirow[b]{2}{*}{$\begin{array}{l}\text { Sample } \\
\text { Size (Age) }\end{array}$} & \multirow[b]{2}{*}{ Drink (Volume/Vehicle) } & \multirow[b]{2}{*}{$\begin{array}{c}\text { Design } \\
\text { (Within or } \\
\text { Between Subjects) }\end{array}$} & \multicolumn{12}{|c|}{ Cognitive Outcomes } \\
\hline & & & & & 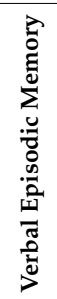 & 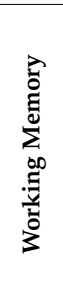 & 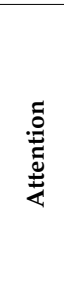 & 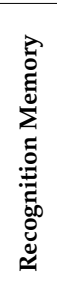 & 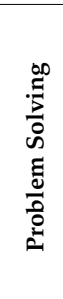 & 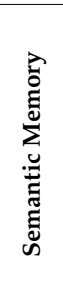 & 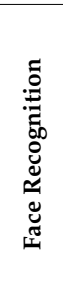 & 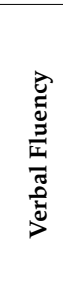 & 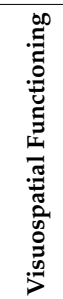 & 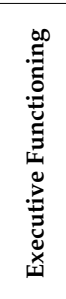 & 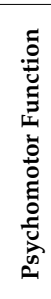 & 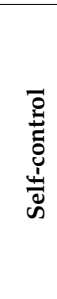 \\
\hline Fructose & Miller et al. 2013 [24] & $36(M=23.25)$ & $\begin{array}{l}(300 \mathrm{~mL}) 25 \mathrm{~g} \text { glucose vs. } 25 \mathrm{~g} \text { fructose } \\
\text { vs. sucralose placebo }\end{array}$ & Between ( $3 \mathrm{~h}$ fast) & & & & & $\mathbf{O}$ & & & & & & & \\
\hline \multirow{4}{*}{ Sucrose } & Kashimura et al. 2003 [117] & $14(M=40.2)$ & $\begin{array}{l}(200 \mathrm{~mL}) 40 \mathrm{~g} \text { sucrose vs. } \\
40 \mathrm{~g} \text { Palatinose }\end{array}$ & Between (12 h fast) & & & $\mathrm{O}$ & & & & & & & & & \multirow{4}{*}{$\mathrm{O}^{2}$} \\
\hline & Harte \& Kanarek, 2004 [115] & $14(18-20)$ & $\begin{array}{l}\text { (227.3 } \mathrm{mL} \text { ) Lemonade ( } 17 \mathrm{~g} \text { sucrose) vs. } \\
\text { aspartame placebo }\end{array}$ & Within (2 h fast) & & & $\mathbf{O}^{1}$ & & & & & & o & & & \\
\hline & Gailliot et al. 2009 [108] & 56 & (397.7 mL) Sucrose vs. sucralose & Between & & & & & & & & & & & & \\
\hline & Dye et al. 2010 [116] & $24(18-32)$ & $\begin{array}{l}(429 \mathrm{~mL}) \text { Milk-based drink containing } \\
\text { isomaltulose vs. sucrose vs. water }\end{array}$ & Within (overnight fast) & - & - & & & & & & & & & - & \\
\hline \multirow{3}{*}{ Isomaltulose } & Kashimura et al. 2003 [117] & $14(M=40.2)$ & $\begin{array}{l}(200 \mathrm{~mL}) 40 \mathrm{~g} \text { sucrose vs. } \\
40 \mathrm{~g} \text { Palatinose }\end{array}$ & Between (12 $\mathrm{h}$ fast) & & & o & & & & & & & & & \\
\hline & Kashimura et al. 2003 [117] & $14(M=32.8)$ & $\begin{array}{c}\text { (185 g) } 5 \text { g Palatinose vs. }(180 \text { g) } \\
10 \text { g Palatinose }\end{array}$ & Between (12 h fast) & & & $\mathbf{O}$ & & & & & & & & & \\
\hline & Dye et al. 2010 [116] & $24(18-32)$ & $\begin{array}{l}(429 \mathrm{~mL}) \text { Milk-based drink containing } \\
\text { isomaltulose vs. sucrose vs. water }\end{array}$ & Within (overnight fast) & - & - & & & & & & & & & - & \\
\hline
\end{tabular}

O Significant effect;- -No effect; X Impairment; ${ }^{1}$ Interactive, additive effects when combined with nicotine gum; ${ }^{2}$ Reduced stereotyping and prejudice attitudes. 


\subsubsection{Isomaltulose}

Isomaltulose (Palatinose ${ }^{\mathrm{TM}} ; 6-0-\alpha$-D-glucopyranosyl-D-fructofuranose) is a naturally occurring, digestible disaccharide ( $\mathrm{C} 12 \mathrm{H} 22 \mathrm{O} 11)$ composed of a glucose and fructose molecule bound by a $\alpha-1,6$-glycosidic bond [118]. Isomaltulose is an isomer of sucrose and is similar in taste, appearance and nutritional content but has $<50 \%$ of the sweetening potential. Isomaltulose has a low glycemic value (32) which results in a slower post-consumptive rise in blood glucose and insulin production [118]. The slow absorption rate maintains raised blood glucose levels for a period of up to four hours [119]. Since isomaltulose enters the blood stream at a slower rate than sucrose, and produces lower postprandial glycemic responses [120], it is suitable for diabetics. It has also been shown to improve glycemic control in healthy men [121].

Evidence for the facilitative cognitive effects of isomaltulose is inconsistent. Isomaltulose and sucrose $(40 \mathrm{mg})$ both significantly increased sustained calculation performance on a high demand task 90 min. post-consumption [117]. This performance enhancement had decreased in the sucrose, but was maintained in the isomaltulose, condition by $150 \mathrm{~min}$. post-consumption. However, the two treatments were not compared statistically. Contrastingly, Dye et al. [116] found no consistent effects of an isomaltulose or sucrose milk-based drink on psychomotor performance, verbal or working memory in young healthy males.

There is modest evidence to suggest isomaltulose may proffer facilitative benefits in children. Two studies have examined the effects of adding isomaltulose to growing up milk (GUM) as a breakfast replacement or as a sweetener in a cereal based breakfast. The GUM studies were conducted in 5-6 year old children in Indonesia [122] and Malaysia [123]. Both studies documented a decline in multiple domains of cognitive performance over the morning. Isomaltulose GUM resulted in the lowest decrement in performance in a number of cognitive domains $+3 \mathrm{~h}$ post-consumption [122,123]. However, better spatial working memory and recognition memory were found following ingestion of glucose [123]. Young and Benton [124] found no effects on cognition one hour after an equicaloric, macronutrient matched breakfast sweetened with isomaltulose or glucose in 5-11 years old children. However, improved memory and mood were observed $+3 \mathrm{~h}$ following the isomaltulose sweetened breakfast.

\subsection{Summary and Unanswered Questions}

It is still commonly reported that $25 \mathrm{~g}$ of glucose is the most reliable dose for moderation of cognitive function, specifically, verbal episodic memory. However, there is sufficient evidence to suggest the 'optimal' dose may be dependent upon a number of mediating factors. Factors contributing to the differential susceptibility to glucose facilitation include age, task difficulty/demand, task domain, glucoregulatory control and BMI. These factors can act as direct response modifiers (e.g., task difficulty), or indirect response modifiers (e.g., glucoregulatory mechanisms, age, BMI).

Whilst there is some evidence to suggest that the memory enhancing effect of glucose follows an inverted U-shaped curve for verbal episodic memory tasks, dose-response curves may differ depending on the cognitive domain assessed. There is a distinct lack of studies that systematically vary the dose of glucose to determine the facilitative dose response effect for cognitive domains other than episodic memory. Therefore, failure to observe robust facilitation on certain cognitive tasks may simply be due to suboptimal dosing. Further research is needed to fully differentiate between the response profiles of glucose administration for different cognitive domains. Dose-response studies of other $\mathrm{CHOs}$ are also required.

Cognitive demand has been emphasized as a key moderator of the glucose facilitation effect, but little attempt has yet been made to define this in terms of task domain. Further examination of memory vs. non-memory tasks with variations in cognitive load is required. There are also inconsistencies in the evidence, and the proposed mechanisms of this effect are poorly explicated suggesting further examination of this moderating factor is required. 
The exact role of glucoregulatory control requires further investigation due to inconsistent evidence of specific facilitation in poor and good glucoregulators. Future research should also establish which glucoregulatory index is the most efficacious predictor of the glucose effects on cognitive function. Presently, there is no consensus with regards the index of glucoregulatory control that best predicts enhanced performance in normoglycemic samples. Methods of classifying glucoregulation employed to date include fasting blood glucose levels, peak glucose levels, recovery and evoked glucose to baseline levels, and area under the curve (AUC). Implementation of the oral glucose tolerance test (OGTT) for classification purposes will help establish which glucoregulatory index is the better predictor of glucose effects on cognition. However, to date the OGTT has also been inconsistently employed (e.g., use of de-gassed Lucozade, normal Lucozade, glucose tablets dissolved in different volumes of water, timing of post ingestion capillary or venous samples, use of devices to measure these samples, period of follow-up post ingestion and analysis performed; cf. [125]).

Evidence of non-metabolic effects of glucose facilitation have been demonstrated. For example, the facilitative rewarding effect of oral rinsing, and the moderating effects of subjective expectancy and thirst. Such findings have important implications for understanding the enhancement of cognitive function by $\mathrm{CHO}$ intake. These effects merit further examination and at the very least should be controlled for or taken into account in the design of the dose response studies recommended.

There is limited support for the facilitative effects of non-glucose $\mathrm{CHOs}$ on cognitive functions but there are significant gaps in the evidence. The specific post-ingestive metabolic effects of fructose can be utilized to further examine potential non-metabolic effects of $\mathrm{CHOs}$ on cognitive performance. Evidence of positive effects of isomaltulose on cognitive performance is largely lacking other than in studies of potentially undernourished children in South East Asia. These samples may be more dependent on a ready supply of energy, such that any facilitative effects may be due to correcting a nutritional deficit. Thus, these studies do not provide robust indications for possible effects in well-nourished adults.

\section{Glycemic Response and Cognitive Performance}

\subsection{Manipulating Glycaemic Response}

The majority of studies investigating the effects of $\mathrm{CHO}$ on cognitive performance have been placebo-controlled, glucose drink interventions. A number of studies have investigated the effect of different $\mathrm{CHO}$ s on cognitive performance rather than just pure glucose drinks. Food interventions are typically described using terms such as glycemic index (GI), glycemic load (GL), the ratio of slowly to rapidly available glucose, the proportion of simple to complex carbohydrate, or the amount of rapidly vs. slowly digested carbohydrate. All can be considered indices of the glycemic potency of foods. The quality (e.g., type, source) and the quantity of $\mathrm{CHO}$ are important determinants of glycemic response. Glycemic index compares equal quantities of available $\mathrm{CHO}$ and thus provides a measure of $\mathrm{CHO}$ quality (not quantity). The GL of a food is a function of its GI and the amount of $\mathrm{CHO}$ per serving. Therefore, GL provided information about the quantity of $\mathrm{CHO}$ and reflects the glycemic response to food portions [126]. Indeed, stepwise increases in GL predict stepwise elevations in postprandial blood glucose/insulin response [127].

Glucose index reflects the rate at which an ingested substance increases and maintains blood glucose levels. High GI foods are characterized by elevated glycemic responses of short duration and a rapid return to basal levels, low GI foods typically elicit slower, more evenly sustained glycemic responses, and a slower return to basal levels over the postprandial period [126]. Therefore, food with a low GI may offer the benefit of counteracting the low blood glucose which may occur with high-GI foods in the later postprandial phase [128]. Hypoglycemia has been demonstrated to significantly impair cognitive function when induced experimentally in healthy young adults [129]. Changes in metabolite concentrations during the post-prandial period have been demonstrated to be more important determinants of cognitive performance than rather than absolute values $[130,131]$. 
This suggests the potential facilitative effects of a more balanced, steady post-prandial glycemic response, typical of low GI foods, on cognitive performance. Low GI foods induce a more moderate blood glucose peak and may maintain a prolonged net blood glucose increment above basal levels. This offers the potentially enhancing effects of maintaining adequate blood glucose availability for uptake into the brain, and additionally, may acutely improve insulin sensitivity which hypothetically offers additional benefits to postprandial performance [132].

Manipulations, that modulate glycemic and insulin response, may provide useful experimental models to examine cognitive effects. The majority of previous evidence of the enhancing effects of $\mathrm{CHO}$ pertains to facilitation within $1 \mathrm{~h}$ of an acute glucose load. A number of studies have demonstrated enhanced cognitive performance over longer postprandial periods by manipulating the GI and/or GL of food. Studies examining cognitive performance in children after breakfasts varying in GI have predominated. Modest evidence of a protective effect of low GI breakfasts on cognitive performance in children over prolonged periods of the morning has been demonstrated $[133,134]$. The effects of breakfasts on children's performance may vary across cognitive domains as a function of GL and GI content [135].

Only a small number of studies have examined the effect of manipulating glycemic response on cognitive performance in the young and healthy (summarized in Table 4). The majority of this data also comes from one laboratory. Studies have focused upon breakfast manipulations and, analogous with the glucose and cognitive performance literature, have predominantly measured episodic memory. The manipulation of the rate at which glucose is made available in the blood by high and low glycemic breakfasts has resulted in facilitative effects on performance. Benton and colleagues $[136,137]$ have shown that low GI breakfasts improve episodic memory in the late postprandial stage (150-210 min). However, no concomitant differences in blood glucose were observed in one study so the facilitative effect on cognitive outcomes cannot be attributed to late glycaemia per se. Conversely, Smith and Foster [6] reported no significant differences in episodic memory performance related to the GI of breakfasts. However, manipulation of glycemic index of breakfasts did not result in divergent blood glucose response profiles.

Individual differences in glucose tolerance may interact with glycemic load to moderate cognitive performance. For example, Nabb and Benton [138] examined the effects of eight breakfasts differing in GI, amount of $\mathrm{CHOs}$ and fiber. Poorer glucose tolerance resulted in more forgetting when higher levels of CHOs were consumed. Higher amounts of CHOs improved reaction time after $90 \mathrm{~min}$ in the poor glucose regulators. The lowest levels of fiber $(1.5 \mathrm{~g})$ were associated with poorer memory in subjects with poorer glucose tolerance. However, blood glucose responses were not affected by dietary fiber content, indicating that the expected variation in GI was not elicited by the composite meals, but the timing of blood glucose sampling was such that differences may have been missed. Nabb and Benton [139] also administered eight different breakfasts differing in energy content, level of CHO (24 g or $59 \mathrm{~g}$ ), fat ( $1 \mathrm{~g}$ or $16 \mathrm{~g}$ ) and protein $(2 \mathrm{~g}$ or $10 \mathrm{~g}$ ). Better glucose tolerance (categorized by fasting blood glucose levels) was associated with superior episodic memory performance. Low energy intake and low blood glucose were also associated with improved performance. Conversely, attentional vigilance and RT were enhanced in participants with good glucose tolerance and high blood glucose levels. 
Table 4. Summary of studies examining the effects of manipulating glycemic response on cognitive performance domains.

\begin{tabular}{|c|c|c|c|c|c|c|c|c|c|c|}
\hline \multirow[b]{2}{*}{ Authors } & \multirow[b]{2}{*}{$\begin{array}{l}\text { Sample Size } \\
\text { (Age) }\end{array}$} & \multirow[b]{2}{*}{ Intervention } & \multirow[b]{2}{*}{$\begin{array}{l}\text { Design } \\
\text { (Within or } \\
\text { Between } \\
\text { Subjects) }\end{array}$} & \multicolumn{6}{|c|}{ Cognitive Outcomes } & \multirow[b]{2}{*}{$\begin{array}{l}\text { Moderating Effect of Postprandial } \\
\text { Glycemic Response }\end{array}$} \\
\hline & & & & 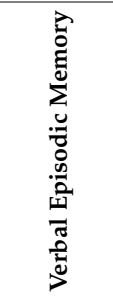 & 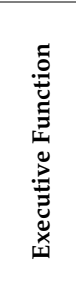 & 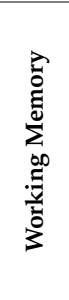 & 䒿 & 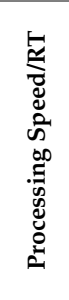 & 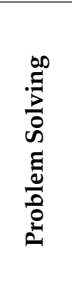 & \\
\hline $\begin{array}{l}\text { Benton et al. } \\
2003[137]\end{array}$ & $\begin{array}{c}71 \\
(M=21)\end{array}$ & $\begin{array}{l}\text { High-SAG biscuit, } 50 \mathrm{~g}: 34 \mathrm{~g} \text { CHO }(8 \mathrm{~g} \text { SAG }+20 \mathrm{~g} \text { RAG, } \\
\mathrm{GI}=42) \text { vs. Low-SAG cereal bar, } 50 \mathrm{~g}: 31 \mathrm{~g} \text { CHO }(0.05 \mathrm{~g} \\
\text { SAG + } 21 \mathrm{~g} \text { RAG, GI = 66) }\end{array}$ & $\begin{array}{c}\text { Between } \\
\text { (overnight fast) }\end{array}$ & $\mathrm{O}$ & & & & & & Enhanced after low GI at $150 \& 210 \mathrm{~min}$ \\
\hline $\begin{array}{l}\text { Benton \& Nabb } \\
\quad 2004[136]\end{array}$ & $\begin{array}{c}323 \\
(M=21)\end{array}$ & $\begin{array}{c}\text { No breakfast vs. High-SAG biscuit, } 50 \mathrm{~g}: 34 \mathrm{~g} \text { CHO } \\
\text { (7.9 g SAG, } 18.8 \mathrm{~g} \text { RAG, GI = 42) vs. Low-SAG cereal bar, } 49 \mathrm{~g} \text { : } \\
\text { 34 g CHO (0.4 g SAG + 21.6 g RAG, GI = 66) or } \\
(0.05 \mathrm{~g} \mathrm{SAG}+21.10 \mathrm{~g} \mathrm{RAG})\end{array}$ & $\begin{array}{c}\text { Between } \\
\text { (overnight fast) }\end{array}$ & $\mathbf{O}$ & & & - & & & Enhanced after low GI at $210 \mathrm{~min}$ \\
\hline $\begin{array}{l}\text { Nabb \& Benton, } \\
\text { 2006b [139] }\end{array}$ & $\begin{array}{c}189 \\
(M=20)\end{array}$ & $\begin{array}{l}8 \text { breakfast conditions differing in energy }(114-407 \mathrm{kcal}), \& \\
\text { contained either low or high levels of CHO }(24 \text { or } 59 \mathrm{~g}) \\
\text { fat }(1 \text { or } 16 \mathrm{~g}) \text { or proteins ( } 2 \text { or } 10 \mathrm{~g})\end{array}$ & $\begin{array}{c}\text { Between } \\
\text { (overnight fast) }\end{array}$ & $\mathbf{O}$ & & & $\mathbf{O}$ & $\mathbf{O}$ & & $\begin{array}{l}\text { Episodic: better glucose tolerance, low } \\
\text { caloric intake \& lower levels of blood } \\
\text { glucose = enhanced performance. RT \& } \\
\text { vigilance: better glucose tolerance, higher } \\
\text { levels of blood glucose = faster RT and } \\
\text { better vigilance }\end{array}$ \\
\hline $\begin{array}{l}\text { Nabb \& Benton, } \\
\text { 2006a [138] }\end{array}$ & $\begin{array}{c}168 \\
(M=20)\end{array}$ & $\begin{array}{c}8 \text { breakfast conditions differing in contents of available CHO } \\
\text { and dietary fiber: Low carb }(15 \mathrm{~g}) \text { with low or medium DF } \\
\text { [100 mL milk vs. Medium CHO ( } 30 \mathrm{~g}) \text { with low, medium or } \\
\text { high DF } \\
\text { [200 mL milk] vs. High CHO }(50 \mathrm{~g}) \text { with low, } \\
\text { medium or high DF [200 mL milk] }\end{array}$ & Between & $\mathbf{O}$ & & & & & & $\begin{array}{l}\text { Episodic: high carb meal + better glucose } \\
\text { tolerance = forgot less words vs. poor } \\
\text { glucose tolerance ppts. Poor glucose } \\
\text { tolerance + low carb meal = forgot less } \\
\text { words vs. high carb meal \& poorer word } \\
\text { recall after low vs. high fiber. Attention: } \\
\text { better glucose tolerance + medium and high } \\
\text { carb meals = faster RT }(90 \mathrm{~min}) \\
\end{array}$ \\
\hline $\begin{array}{l}\text { Smith \& Foster, } \\
\quad 2008[6]\end{array}$ & $\begin{array}{c}36 \\
(M=15.6)\end{array}$ & $\begin{array}{l}30 \mathrm{~g} \text { All-Bran }(\mathrm{GI}=30) \text { vs. } 30 \mathrm{~g} \text { Cornflakes }(\mathrm{GI}=77) \\
\text { Served with } 125 \mathrm{~mL} \text { of milk }\end{array}$ & $\begin{array}{c}\text { Between } \\
\text { (overnight fast) }\end{array}$ & ${ }^{-\mathrm{a}} \mathbf{O}^{\mathrm{a}}$ & & & & & & $\begin{array}{l}\text { Episodic: no effect on verbal learning. High } \\
\text { GI = fewer items forgotten in long delay } \\
\text { recall vs. short delay (vs. low GI) }\end{array}$ \\
\hline $\begin{array}{l}\text { Micha et al. } \\
2010[135]\end{array}$ & $\begin{array}{c}60 \\
(M=13)\end{array}$ & $\begin{array}{l}\text { Classification of habitual breakfast intake into } 4 \text { groups: HIGH } \\
\text { GL:low or high GI and LOW GL:low or high GI }\end{array}$ & $\begin{array}{c}\text { Between } \\
\text { (overnight fast) }\end{array}$ & $\mathbf{O}^{\mathrm{a}, 1-\mathrm{b}}$ & - & $\mathrm{O}^{2}$ & & $\mathrm{O}^{2}$ & $\mathrm{O}^{3}$ & $\begin{array}{c}\text { Fractionation of effects on specific cognitive } \\
\text { tests by GL and GI breakfast forms. } \\
\text { Enhancing effects in High GL forms which } \\
\text { were associated with higher BG levels } \sim 120 \\
\text { min post ingestion }\end{array}$ \\
\hline
\end{tabular}

O Significant effect;-No effect; X Impairment GL—glycemic load; GI—glycemic index; SAG—slowly available glucose; RAG—rapidly available glucose; CHO—carbohydrate; DF—dietary fiber; ${ }^{a}$ Effects under dual task paradigm; ${ }^{b}$ Immediate word recall; ${ }^{1}$ High GI breakfast only; ${ }^{2}$ Low-GI, high-GL breakfast only; ${ }^{3}$ High-GL breakfast only. 
The conclusions from studies available to date are tempered by a range of methodological limitations (e.g., poor descriptions of meals or products ingested as well as of cognitive tests administered, insufficient standardization of the available carbohydrate content and nutrient composition of the meals, lack of adequate information on, or physiological confirmation of, the course of postprandial glycaemia, insufficient duration of the meal test and subsequent test period, or too few test subjects). The evidence to date generally favors low GI meals for improved memory and/or attention in children and elderly, and mainly in the late postprandial phase [128]. The evidence in young, healthy adults is equivocal at the present time. The beneficial effects of low GI meals may be secondary to a smoother overall blood glucose profile with sustained availability of glucose to the brain and/or to an acute improvement in insulin sensitivity. Further studies are necessitated to identify the mechanisms underpinning the facilitative effects of low GI food intake considering effects have been shown independent of divergent blood glucose response profiles. Studies of the impact of habitual consumption of low-GI vs. high-GI diets on cognitive performance are also required.

\subsection{Moderation of Glycaemic Response by Vehicle}

Manipulation of the glycemic response to foods through ingredient selection and engineering novel food structures has attracted increasing interest $[140,141]$. Monosaccharides and disaccharides are rapidly absorbed and elicit a rapid rise in blood glucose. Oligosaccharides (e.g., maltodextrins) and polysaccharides (e.g., starch) elicit a smaller glycemic response which may proffer benefits by maintaining the glucose response over longer timescale. For example, intake of a low GI mixture of saccharides (sucromalt) improved subjective mental energy and attenuated fatigue over 4-5 h postprandially [142]. The presence of other food constituents, such as fats and proteins, can also alter the rate of glucose absorption. These substances may, in consequence, alter the effects of glucose on cognitive performance. A number of macronutrients have potential glycemic response moderating qualities that may offer beneficial effects on postprandial glucose response profiles. The capacity of dietary fibers to reduce the overall postprandial glucose response has been demonstrated. For example, oat bran [143] and psyllium (a seed derived husk fiber [144]) regulate the rate and extent of CHOs degradation and subsequent release of glucose into the blood. Protein fractions also have significant capacity to reduce glycemic response. Milk-derived proteins are insulinogenic. Intake of $18 \mathrm{~g}$ of milk-derived whey protein significantly increased insulin response and lowered post-prandial glycaemia compared to white bread and controls $[145,146]$. A whey protein fraction has also been demonstrated to reduce glycaemia compared to a glucose reference drink in a dose-dependent manner (obese sample [147]). Gunnerud et al. [148] replicated this finding in healthy participants. Further, the insulinogenic properties of whey proteins were shown to likely be mediated by the postprandial plasma amino-acid (AA) response; whey protein affected glycaemia, insulinaemia and plasma AA response to a glucose load in a dose-dependent manner. Nine grams of whey protein was sufficient to reduce postprandial glycaemia when added to a carbohydrate-rich meal.

The potential facilitative cognitive effects of modulating the glycemic response to a glucose load by vehicle has received little attention. The available evidence offers limited support. For example, Sünram-Lea et al. [149] combined $25 \mathrm{~g}$ of glucose or aspartame with full fat or a fat-free yoghurt. The highest blood glucose levels were elicited by glucose combined with a fat-free yoghurt and resulted in subsequent superior short- and long-term episodic memory performance. The co-administration glucose and fat attenuated the glycemic response but no facilitative effects of glucose were demonstrated. Therefore, the slowing of glucose metabolism by fat did not result in improved performance. The authors suggest glucose may only exert its full facilitative effects if a peripheral/central facilitative glucose level is reached within a short timeframe. However, this study only examined cognitive performance up to $45 \mathrm{~min}$. postprandially; facilitative effects of glycemic load manipulations may only emerge $\geq 150 \mathrm{~min}[136,137]$. Dye et al. [116] manipulated the glycemic response with isomaltulose in a milk drink. However, no facilitative effects were observed despite an attenuation of postprandial response. 


\subsection{Summary and Unanswered Questions}

The studies described above were conducted in healthy young adults using between subjects designs in which participants did not act as their own controls. The beneficial effects observed on cognitive function were apparent not at the point at which glucose levels were significantly different, but later in the post prandial period when glucose levels had returned to baseline. This could be interpreted to indicate that the metabolic challenge of a high glycemic response was more detrimental to performance even in young healthy, cognitively able, participants than the more slowly released glucose from the low GI treatment. These inferences require verification in within subjects designs with more careful control of the antecedent conditions prior to ingestion, and the use of glucose measurement that is more sensitive to change in the euglycemic range and more frequently assessed-in these studies measurements were taken usually every 30 min using devices intended to detect hyper- or hypoglycemia.

The vehicle in which ingredients selected are provided is also an important consideration. Dairy based vehicles may be insulinotrophic and modulate the glycemic response to produce a low GI profile but it is not known whether this will facilitate cognitive function and indeed only studies in nutritionally vulnerable children have demonstrated positive effects; the only study conducted in western adults did not.

There is insufficient evidence to support cognitive benefits of GL manipulations. Physiological processes other than glycaemia, such as insulinaemia, may be more closely related to changes in cognitive performance and merit systematic investigation.

\section{Caffeine, Carbohydrates, and Cognitive Function}

\subsection{Caffeine}

Caffeine is a plant and seed-derived methylxanthine that acts as a central nervous system stimulant in humans [150]. Caffeine is rapidly absorbed into the bloodstream post-ingestion via the gastrointestinal tract and can pass freely across all biological membranes, including the BBB [151]. The biological effects of caffeine are mediated by its antagonistic effects on adenosine receptors which are widely dispersed in gastrointestinal, cardiovascular, respiratory, renal, and central nervous systems [152], including the brain [153]. By inhibiting adenosine receptors, caffeine increases the release of neurotransmitters, including noradrenaline, dopamine and acetylcholine which have diverse physiological effects throughout the body (e.g., vasoconstriction in the periphery, increased blood pressure, thermogenesis, and increased renal and gastric function [154]).

The potential facilitative effects of caffeine intake on cognitive performance and psychological state have been widely examined (e.g., [155-157]). Broadly, performance enhancing effects have been demonstrated on psychomotor, attention, and vigilance tasks [155,158]; a less consistent effect on memory has also been reported [157,159]. Caffeine has also been consistently associated with moderation of mood, particularly increased subjective arousal, alertness and reduced mental fatigue [157,159]. The majority of this research has examined caffeine facilitation 30-60 min, after intake. Indeed, the peak maximum blood plasma concentration of caffeine is typically reached within at least an hour (e.g., [160]). The dose of caffeine commonly administered in such studies typically exceeds the natural dose present in coffee and tea (30-120 mg depending on type of bean/leaf and brewing method). For example, $250 \mathrm{mg}$ of caffeine improves visual search performance, spatial selective attention and perceptual sensitivity [161,162]. However, performance enhancements have been demonstrated at lower doses ranging from 32 to $50 \mathrm{mg}$ [163-165], and performance detriments at high doses (e.g., $400 \mathrm{mg}$ [166]). A recent scientific opinion from the European Food Standards Agency (EFSA) upheld the claim that caffeine increased alertness (indexed by RT) and attention (indexed by a range of psychometric tasks) in healthy individuals of both sexes [167]. This ruling on the facilitative effects of caffeine intake was specific to doses of at least $75 \mathrm{mg}$ of caffeine. A more recent ruling rejected a claim for facilitative effects of $40 \mathrm{mg}$ of caffeine [168]. Whilst facilitative effects of caffeine doses $<75 \mathrm{mg}$ on attention and alertness performance have been demonstrated, they were considered less 
consistent and convincing than $\geq 75 \mathrm{mg}$ doses. However, it is considered that this rejection of the facilitative effects of caffeine $<75 \mathrm{mg}$ is underpinned by the quality of the evidence to date rather than the lack capacity of caffeine to moderate cognitive performance at lower doses.

\subsection{Combined Effects of Caffeine and $\mathrm{CHO}$}

\subsubsection{Cognitive Performance Outcomes}

The facilitative effects of glucose and caffeine in isolation are well established (e.g., $[60,155])$. An increase in the consumption of 'energy' drinks, containing, amongst other ingredients, caffeine and $\mathrm{CHOs}$ (predominantly glucose), has intensified research interest into the potential facilitative performance and mood effects of caffeine and CHO in combination $[169,170]$. Table 5 summarizes studies that have examined the cognitive performance and mood effects of combined caffeine and $\mathrm{CHO}$ (glucose and glucose/sucrose/fructose blend) drinks, compared to glucose only, or placebo drinks (CHO- and caffeine-free). Several studies have also employed commercially available energy drinks which contain additional ingredients (e.g., taurine, glucoronolactone, and vitamin). The majority of studies have administered caffeine doses between 30 and $80 \mathrm{mg}$ combined with glucose ranging between 25 and $60 \mathrm{~g}$. The cognitive domains assessed have predominantly matched those established as sensitive to caffeine manipulation, namely, attention, vigilance, perceptual speed, RT, and driving performance. Relatively less attention has been given to cognitive domains shown to be sensitive to glucose intake such as episodic memory.

Significant facilitative effects of caffeine combined with $\mathrm{CHO}$ have been demonstrated for sustained [171-173] and short-term $(<30 \mathrm{~min})$ attention [174]. This includes event-related potential evidence (ERP; an electrophysiological measure of neural response that is considered a marker of sensory, cognitive, or motor neural events) suggesting augmented attentional information processing [172]. Kennedy and Scholey [171] propose the enhancing effects of caffeine and glucose on sustained attention may be predominantly mediated by caffeine since they demonstrated facilitative effects during the temporal period associated with peak plasma caffeine levels ( +35 and $+45 \mathrm{~min}$. post intake). The findings of Warburton [158] also suggest that the effects of caffeine may supersede that of glucose since no effects of glucose were demonstrated when administered alone. However, since both studies did not compare combined caffeine and glucose intake with these nutrients in isolation, this proposition cannot be verified. A facilitative effect of caffeine and glucose on attention has also not been consistently reported [175].

Caffeine and $\mathrm{CHO}$ drinks have improved RT performance in a number of performance domains, including, behavioral control [176], visual attention [174], simple and choice RT (sleep restricted; [177]), sustained attention [172,178], and driving performance [179]. Analogous to the glucose literature, a facilitative effect of caffeine and glucose has been demonstrated under conditions of high cognitive demand. Smit et al. [178] reported enhanced RT whilst completing a fatiguing and cognitively demanding test battery. Similarly, Scholey et al. [180] demonstrated significantly faster mental arithmetic performance during a cognitively demanding multi-tasking paradigm. However, $30 \mathrm{mg}$ caffeine combined with $42 \mathrm{~g}$ sugars (glucose/fructose/sucrose blend) has been demonstrated to impair RT on a psychomotor vigilance task in sleep restricted individuals compared to a no sugar, no caffeine, sweetened control drink [181]. No effects of $80 \mathrm{mg}$ caffeine and $27 \mathrm{~g}$ glucose/sucrose on RT has also been reported [175].

The effect of caffeine and $\mathrm{CHO}$ on driving performance, indexed by lane drifting, deviation of speed, and RT, has been examined. Enhanced effects have been demonstrated in the short-term (effect strongest in the first 60-90 $\mathrm{min}[179,182]$ ) and long-term (effect evident after 3 and $4 \mathrm{~h}$ of prolonged driving [183]). Driver subjective sleepiness has also been examined in such studies. Intake of $80 \mathrm{mg}: 26 \mathrm{~g}$ caffeine:CHO was sufficient to attenuate subjective sleepiness in normal [183] and sleep restricted [182] participants. These effects were evident in the first $90 \mathrm{~min}$. and the $3 \mathrm{rd}$ and 4 th hour of sustained driving. This subjective reduced sleepiness may be specific to driving related tasks as sleepiness levels were not counteracted by intake of $30 \mathrm{mg}: 42 \mathrm{~g}$ caffeine: $\mathrm{CHO}$ during an attention vigilance task in the sleep restricted [181]. However, this effect may be mediated by the lower dose of caffeine administered in this vigilance study. 
Table 5. Summary of studies examining the effects of caffeine and $\mathrm{CHO}$ in combination on cognitive performance and subjective mood.

\begin{tabular}{|c|c|c|c|c|c|c|}
\hline Author & Sample Size (Age) & $\begin{array}{l}\text { Design (Within or } \\
\text { Between Subjects) }\end{array}$ & $\begin{array}{l}\text { Performance Measured } \\
\text { (Relative to } \\
\text { Drink Intake) }\end{array}$ & Drink (Volume/Vehicle) & Outcome Measures & Outcomes \\
\hline $\begin{array}{l}\text { Horne \& Reyner, } \\
\quad 2001[179]\end{array}$ & $11(M=24)$ & $\begin{array}{l}\text { Within (restricted sleep } \\
\text { (5 h); overnight } \\
\text { caffeine fast) }\end{array}$ & $\begin{array}{l}30 \text { min drive- } 30 \text { min } \\
\text { break (drink)-2 h driving }\end{array}$ & $\begin{array}{l}\text { (500 mL) caffeine } 160 \mathrm{mg}+28.25 \mathrm{~g} \text { CHO } \\
(11.3 \mathrm{~g} / 100 \mathrm{~mL}) \text { vs. placebo energy drink }\end{array}$ & $\begin{array}{l}\text { Driving simulator (lane drifting } \\
\text { and RT) }\end{array}$ & $\begin{array}{l}\text { Caffeine }+ \text { CHO significantly improved both } \\
\text { lane drifting and RT. Effect strongest in 1st } h\end{array}$ \\
\hline $\begin{array}{l}\text { Warburton et al. } \\
\text { 2001 [173] }\end{array}$ & $\begin{array}{l}\text { Study 1: 20; Study 2: } \\
\qquad 22 \text { (18-24) }\end{array}$ & $\begin{array}{l}\text { Within }(1 \mathrm{~h} \text { caffeine } \\
\text { abstinence) }\end{array}$ & $+45 \mathrm{~min}$ & $\begin{array}{c}(250 \mathrm{~mL})(\text { Red Bull) } 80 \mathrm{mg} \text { caffeine }+21 \mathrm{~g} \\
\text { sucrose }+5 \mathrm{~g} \text { glucose }+1 \mathrm{~g} \text { taurine vs. } \\
\text { Study 1: sugar-free water; Study 2: water + } \\
\sim 6 \mathrm{~g} \text { glucose }\end{array}$ & $\begin{array}{l}\text { RVIP; verbal reasoning; verbal } \\
\text { and non-verbal memory test; } \\
\text { Bond-Lader mood VAS }\end{array}$ & $\begin{array}{l}\text { Energy drink improved attention, and verbal } \\
\text { reasoning RT vs. glucose and non-glucose } \\
\text { placebo, and reduced variability in RT } \\
\text { performance. No difference between glucose } \\
\text { and non-glucose drinks. No memory effects }\end{array}$ \\
\hline $\begin{array}{l}\text { Reyner \& Horne, } \\
\quad 2002[182]\end{array}$ & $12(M=24)$ & $\begin{array}{l}\text { Within (overnight } \\
\text { caffeine fast; restricted } \\
\text { sleep }(5 \mathrm{~h}) \text { ) }\end{array}$ & $\begin{array}{l}30 \text { min drive-30 min } \\
\text { break (drink)-2 h driving }\end{array}$ & $\begin{array}{l}(250 \mathrm{~mL})(\text { Red Bull) } 80 \mathrm{mg} \text { caffeine }+21 \mathrm{~g} \\
\text { sucrose }+5 \mathrm{~g} \text { glucose vs. placebo version }\end{array}$ & $\begin{array}{l}\text { Driving simulator (lane drifting } \\
\text { and RT); EEG; Karolinska } \\
\text { Sleepiness Scale }\end{array}$ & $\begin{array}{l}\text { Caffeine }+\mathrm{CHO}=\text { reduced sleep-related driving } \\
\text { incidents and subjective sleepiness during the } \\
\text { afternoon. Effect strongest in } 1 \text { st } 90 \mathrm{~min}\end{array}$ \\
\hline $\begin{array}{l}\text { Kennedy \& } \\
\text { Scholey, } \\
2004[171]\end{array}$ & $\begin{array}{l}\text { Study 1: } 30(18-25) ; \\
\text { Study 2: } 26(18-24)\end{array}$ & $\begin{array}{l}\text { Double-blind, } \\
\text { placebo-controlled, } \\
\text { cross-over design }(24 \mathrm{~h} \text {; } \\
\text { overnight fast and } \\
\text { caffeine abstinence) }\end{array}$ & $+10 \mathrm{~min}$ & $\begin{array}{l}\text { Study 1: (380-mL) } 38 \mathrm{mg} \text { caffeine }+68 \mathrm{~g} \\
\text { glucose vs. } 46 \mathrm{mg} \text { caffeine }+68 \mathrm{~g} \text { of } \\
\text { glucose, vs. vehicle placebo; Study 2: } \\
(330-\mathrm{mL}) 33 \mathrm{mg} \text { caffeine }+60 \mathrm{~g} \text { glucose vs. } \\
\text { just the vehicle. }\end{array}$ & $\begin{array}{c}10 \text { min cognitive test battery } \times 6 \\
\text { times }(=60 \text { min cog. demand): } \\
\text { Serial } 3 \mathrm{~s} \text { and } 7 \mathrm{~s} ; \text { RVIP; mental } \\
\text { fatigue VAS }\end{array}$ & $\begin{array}{l}\text { Both studies: improved accuracy of RVIP } \\
\text { performance with all } 3 \text { active treatments. Effects } \\
\text { emerged }+35 \text { ( } 38 \mathrm{~g} \text { and } 46 \mathrm{~g} \text { caffeine) and }+45 \\
\text { ( } 33 \mathrm{~g} \text { caffeine) min after drink intake. } 46 \mathrm{mg} \\
\text { caffeine drink improve WM in initial } 2 \text { blocks. } \\
\text { Higher dose of caffeine }(46 \mathrm{mg} \text { ) and caffeine } \\
\text { drink }(33 \mathrm{mg} \text { ) reduced self-assessed mental } \\
\text { fatigue during the extended period of cognitive } \\
\text { performance (no effect of } 38 \mathrm{~g}=\text { baseline effect?) }\end{array}$ \\
\hline $\begin{array}{l}\text { Smit et al. } \\
2004[178]\end{array}$ & $\begin{array}{l}\text { Study 1: } 28 \text { (18-49); } \\
\text { Study 3: } 97(18-55)\end{array}$ & $\begin{array}{l}\text { Study 1: Within } \\
\text { (overnight caffeine } \\
\text { abstinence); Study 3: } \\
\text { Between (CHO } \\
\text { (breakfast) deprived) }\end{array}$ & $+5-+90 \mathrm{~min}$ & $\begin{array}{l}\text { (250 mL) Study } 1: 75 \mathrm{mg} \text { caffeine }+37.5 \mathrm{~g} \\
\text { glucose vs. placebo vs. water; Study } 3: \\
62.5 \mathrm{mg} \text { caffeine }+37.5 \mathrm{~g} \text { glucose vs. } 62.5 \\
\mathrm{mg} \text { caffeine vs. } 62.5 \mathrm{mg} \text { caffeine }+37.5 \mathrm{~g} \\
\text { glucose non-carbonated }\end{array}$ & $\begin{array}{l}\text { Simple RT; RVIP; immediate and } \\
\text { delayed word recall; letter search } \\
\text { task; mood VAS }\end{array}$ & $\begin{array}{l}\text { Caffeine + glucose drinks improved and/or } \\
\text { maintained mood (arousal) and RT } \\
\text { performance during fatiguing and cognitively } \\
\text { demanding tasks relative to placebo }\end{array}$ \\
\hline $\begin{array}{l}\text { Rao et al. } \\
2005 \text { [172] }\end{array}$ & $40(18-30)$ & $\begin{array}{l}\text { Between (no fasting; } \\
\text { caffeine abstinence on } \\
\text { test day) }\end{array}$ & Not known & $\begin{array}{l}(330 \mathrm{~mL}) 40 \mathrm{mg} \text { caffeine }+60 \mathrm{~g} \text { glucose } \\
\text { syrup vs. sweetness/flavor } \\
\text { matched placebo }\end{array}$ & $\begin{array}{l}\text { BP; HR; EEG; ERP; sustained } \\
\text { selective attention }\end{array}$ & $\begin{array}{l}\text { Glucose }+ \text { caffeine drink }=\text { improved accuracy } \\
\text { and RT on sustained selective-attention task vs } \\
\text { placebo. Glucose + caffeine }=\text { improved } \\
\text { stimulus processing at several stages of } \\
\text { information processing }(\mathrm{ERP})\end{array}$ \\
\hline $\begin{array}{l}\text { Anderson \& } \\
\text { Horne, } \\
2006[181]\end{array}$ & $10(=22.4)$ & $\begin{array}{c}\text { Double blind, crossover } \\
\text { design }(1 \text { week; } \\
\text { restricted sleep }(5 \mathrm{~h}) ; \\
\text { taken with soup lunch; } \\
\sim 14 \mathrm{~h} \\
\text { caffeine abstinence) }\end{array}$ & $+10 \mathrm{~min}$ & $\begin{array}{l}(250 \mathrm{~mL}) 30 \mathrm{mg} \text { caffeine }+42 \mathrm{~g} \text { sugars } \\
\text { (glucose, fructose, sucrose) vs. sugar- } \\
\text { caffeine-free orange flavored drink }\end{array}$ & $\begin{array}{l}\text { Psychomotor Vigilance Test; } \\
\text { Karolinska Sleepiness Scale }\end{array}$ & $\begin{array}{l}\text { Energy drink did not counteract sleepiness and } \\
=\text { slower RTs and more lapses } 80 \mathrm{~min} \\
\text { post-intake }\end{array}$ \\
\hline $\begin{array}{l}\text { Smit et al. } \\
2006[184]\end{array}$ & $76(18-40)$ & $\begin{array}{l}\text { Between (overnight } \\
\text { food and caffeine fast) }\end{array}$ & $+7-+120 \mathrm{~min}$ & $\begin{array}{c}(330 \mathrm{~mL} \text { ) Familiar drink: } 30 \mathrm{mg} \text { caffeine }+ \\
54 \mathrm{~g} \text { glucose vs. familiar drink placebo vs. } \\
\text { Novel drink: } 30 \mathrm{mg} \text { caffeine }+54 \mathrm{~g} \text { glucose } \\
\text { vs. novel drink placebo }\end{array}$ & $\begin{array}{l}\text { Simple RT; RVIP; serial 7's; letter } \\
\text { search task; mood VAS }\end{array}$ & $\begin{array}{l}\text { First exposure: familiar drink and its placebo } \\
\text { improved alertness, mental energy and mental } \\
\text { performance vs. baseline and novel placebo } \\
\text { drink. Repeated exposure/increased familiarity } \\
\text { with the novel drinks: both caffeine + CHO } \\
\text { containing drinks = sustained beneficial effects } \\
\text { vs. placebo drinks and baseline measures }\end{array}$ \\
\hline
\end{tabular}


Table 5. Cont

\begin{tabular}{|c|c|c|c|c|c|c|}
\hline Author & Sample Size (Age) & $\begin{array}{l}\text { Design (Within or } \\
\text { Between Subjects) }\end{array}$ & $\begin{array}{l}\text { Performance Measured } \\
\text { (Relative to } \\
\text { Drink Intake) }\end{array}$ & Drink (Volume/Vehicle) & Outcome Measures & Outcomes \\
\hline $\begin{array}{l}\text { Childs \& de Wit, } \\
2008 \text { [177] }\end{array}$ & $35(18-35)$ & $\begin{array}{c}\text { Within (caffeine } \\
\text { abstinence on test day) }\end{array}$ & $\begin{array}{c}\text { Remained awake } \\
5 \text { p.m. }-5 \text { a.m. Energy } \\
\text { capsule or placebo } 3: 30 \\
\text { a.m. Cog. testing }+30 \mathrm{~min}\end{array}$ & $\begin{array}{c}\text { (Capsule) } 200 \mathrm{mg} \text { caffeine }+50 \mathrm{mg} \text { white } \\
\text { willow bark }+30 \mathrm{mg} \text { magnesium oxide }+ \\
10 \mathrm{mg} \text { taurine }+375 \mathrm{~g} \text { dextrose vs. } 375 \mathrm{~g} \\
\text { dextrose placebo }\end{array}$ & $\begin{array}{l}\text { BP; physical activity meter; } \\
\text { Simple and choice RT task; } \\
\text { POMS and mood VAS }\end{array}$ & $\begin{array}{c}\text { Caffeine }=\text { improved mood and mental energy } \\
\text { and counteracted increases in simple and choice } \\
\text { RT vs. placebo }\end{array}$ \\
\hline $\begin{array}{l}\text { Gendle et al. } \\
2009 \text { [175] }\end{array}$ & $36(18-21)$ & $\begin{array}{l}\text { Within ( } 4 \mathrm{~h} \text { fast and } \\
\text { caffeine abstinence) }\end{array}$ & $+30 \mathrm{~min}$ & $\begin{array}{l}(250 \mathrm{~mL}) 80 \mathrm{mg} \text { caffeine }+1000 \mathrm{mg} \text { taurine } \\
+27 \mathrm{~g} \text { glucose/sucrose vs. sugar and } \\
\text { caffeine free version }\end{array}$ & $\begin{array}{l}\text { Visual attention and RT } \\
\text { (Conner's Continuous } \\
\text { Performance Test II) }\end{array}$ & No effects \\
\hline $\begin{array}{l}\text { Howard \& } \\
\text { Marczinski, } \\
2010[176]\end{array}$ & $80(M=20.1)$ & $\begin{array}{l}\text { Between ( } 2 \mathrm{~h} \text { fast; } 8 \mathrm{~h} \\
\text { caffeine abstinence) }\end{array}$ & $+30 \mathrm{~min}$ & $\begin{array}{l}\text { Energy drink doses calculated by body } \\
\text { weight. Caffeine content for average } 78 \mathrm{~kg} \\
\text { ppt given in (): } 1.8 \mathrm{~mL} / \mathrm{kg} \text { energy drink } \\
(45.6 \mathrm{mg}) \mathrm{vs} .3 .6 \mathrm{~mL} / \mathrm{kg} \text { energy drink } \\
(91.2 \mathrm{mg} / 30.8 \mathrm{~g} \mathrm{CHO}) \text { vs. } 5.4 \mathrm{~mL} / \mathrm{kg} \\
\text { energy drink ( } 136.7 \mathrm{mg}) \text { vs. } 3.6 \mathrm{~mL} / \mathrm{kg} \\
\text { placebo drink (29.3 g CHO) vs. no drink) }\end{array}$ & $\begin{array}{l}\text { Cued go/no-go task; mental } \\
\text { fatigue VAS }\end{array}$ & $\begin{array}{c}\text { Energy drink = increased stimulation, } \\
\text { decreased mental fatigue, and decrease } \\
\text { behavioral control RT. No effect on response } \\
\text { inhibition. Lowest caffeine dose = greater RT } \\
\text { and subjective measure improvement. } \\
\text { Improvements diminished as the dose increased }\end{array}$ \\
\hline $\begin{array}{l}\text { Mets et al. } \\
2011 \text { [183] }\end{array}$ & $24(M=21-35)$ & Within & $\begin{array}{l}\text { Drive } 2 \mathrm{~h} \text {-drink } \\
\text { intake-drive } 2 \mathrm{~h}\end{array}$ & $\begin{array}{c}(250 \mathrm{~mL})(\text { Red Bull) } 80 \mathrm{mg} \text { caffeine }+21 \mathrm{~g} \\
\text { sucrose }+5 \mathrm{~g} \text { glucose }+1 \mathrm{~g} \text { taurine }+ \text { vs. } \\
\text { placebo (Red bull) drink }\end{array}$ & $\begin{array}{l}\text { STISIM Drive } \\
\text { simulator driving } \\
\text { laterandard position (SDLP); standandard } \\
\text { deviation of speed); subjective } \\
\text { driving quality and mental effort; } \\
\text { Karolinska Sleepiness Scale }\end{array}$ & $\begin{array}{l}\text { Energy drink significantly improved driving } \\
\text { relative to placebo: SDLP reduced in 3rd and } \\
\text { 4th h. Reduced standard deviation of speed, } \\
\text { improved subjective driving quality, and } \\
\text { reduced mental effort during 3rd hr. Subjective } \\
\text { sleepiness was significantly decreased in 3rd } \\
\text { and 4th h of driving }\end{array}$ \\
\hline $\begin{array}{l}\text { Aniţei et al. } \\
2011[174]\end{array}$ & $153(18-21)$ & Between & $+40 \mathrm{~min}$ & $\begin{array}{l}275 \mathrm{mg} \text { caffeine coffee vs. energy drink } \\
(1000 \mathrm{mg} \text { taurine }+80 \mathrm{mg} \text { caffeine }+ \\
\text { sucrose/glucose (not stated) vs. } 275 \mathrm{mg} \\
\text { caffeine + energy drink vs. no drink }\end{array}$ & $\begin{array}{l}\text { Perceptual speed; visual and } \\
\text { auditory attention RT; visual } \\
\text { orientation performance; } \\
\text { vigilance test }\end{array}$ & $\begin{array}{l}\text { Caffeine alone and combined with CHO in } \\
\text { energy drink increased motor reactivity, } \\
\text { short-term attention (under } 30 \mathrm{~min} \text { ) and visual } \\
\text { attention RT. Effects less consistent/smaller } \\
\text { when caffeine and energy drink combined } \\
\text { (365 mg caffeine) }\end{array}$ \\
\hline $\begin{array}{l}\text { Sünram-Lea et } \\
\text { al. } 2012[185]\end{array}$ & $81(M=26)$ & $\begin{array}{l}\text { Between (overnight fast } \\
\text { + standardized } \\
\text { breakfast; caffeine } \\
\text { abstinence } \\
\text { from waking) }\end{array}$ & $\begin{array}{l}+10 \text { (pre-stressor) and } \\
+60 \text { min (post-stressor) }\end{array}$ & $\begin{array}{c}\text { (330-mL) } 40 \mathrm{mg} \text { caffeine }+50 \mathrm{~g} \text { glucose vs. } \\
80 \mathrm{mg} \text { caffeine }+10.25 \mathrm{~g} \text { fructose } \\
(41 \%) / \text { glucose }(59 \%) \text { vs. placebo drink }\end{array}$ & $\begin{array}{l}\text { Salivary cortisol; CBG; } \\
\text { immediate and delayed free } \\
\text { word call; letter cancellation task; } \\
\text { grammatical reasoning task; } \\
\text { letter digit substitution task; } \\
\text { hand grip strength }\end{array}$ & $\begin{array}{l}50 \mathrm{~g} \text { glucose }+40 \mathrm{mg} \text { caffeine }=\text { increased grip } \\
\text { strength and improved memory performance. } \\
\text { Both active drinks }=\text { improved information } \\
\text { processing (letter-digit substitution task) } \\
\text { performance vs. placebo. } 50 \mathrm{~g} \text { glucose } / 40 \mathrm{mg} \\
\text { caffeine = reduced anxiety and subjective stress. } \\
\text { No effects on reasoning and attention or } \\
\text { subjective alertness }\end{array}$ \\
\hline $\begin{array}{l}\text { Scholey et al. } \\
2014 \text { [180] }\end{array}$ & $150(18-55)$ & $\begin{array}{l}\text { Between }(12 \mathrm{~h} \text { fast and } \\
\text { caffeine abstinence) }\end{array}$ & $+30 \mathrm{~min}$ & $\begin{array}{l}(330 \mathrm{~mL}) 40 \mathrm{mg} \text { caffeine }+60 \mathrm{~g} \text { glucose vs. } \\
25 \mathrm{~g} \text { glucose vs. } 60 \mathrm{~g} \text { glucose }\end{array}$ & $\begin{array}{l}\text { CBG; salivary caffeine level; } \\
\text { multi-tasking framework } \\
(4 \text { simultaneous tasks: } \\
\text { mathematical processing task; } \\
\text { stroop; memory search; target } \\
\text { tracker task); Bond-Lader mood } \\
\text { VAS; stress and fatigue VAS }\end{array}$ & $\begin{array}{l}\text { Co-administration of glucose and caffeine = } \\
\text { greater multi-tasking performance than placebo } \\
\text { or glucose alone }\end{array}$ \\
\hline
\end{tabular}


Sünram-Lea et al. [185] provide further evidence of the potential facilitative effects of caffeine and $\mathrm{CHO}$ in demanding contexts. Adding to evidence of performance facilitation under conditions of high cognitive demand and in the sleep deprived state, these authors reported positive cognitive effects of caffeine and $\mathrm{CHO}$ in individuals under conditions of stress. Activation of the psychoneuroendocrine stress response systems-the hypothalamic-pituitary-adrenal [HPA] axis and sympathetic-adrenal-medullary [SAM] system-increases the availability of metabolic glucose to cope with the demands of the stressor via the release of cortisol and adrenaline. Cortisol increases liver gluconeogenesis and decreases glucose absorption in the periphery; adrenaline increases circulating blood glucose levels via the liver. The magnitude of cortisol response to stress is moderated by glycemic status [186,187] and the release of cortisol under conditions of stress is associated with impaired cognitive function [188]. The intake of a glucose load post-stress exposure has been demonstrated to attenuate the cortisol stress response [189]. Therefore, a caffeine and glucose drink has the potential to offer performance benefits under stressful conditions. Indeed, Sünram-Lea et al. [185] report increased grip-strength and episodic memory (delayed word recall) after intake of a $40 \mathrm{mg}: 50 \mathrm{~g}$ caffeine:glucose drink following a fire fighting training exercise. Further, information processing was also enhanced with this dose drink and additionally with a $80 \mathrm{mg}: 12.5 \mathrm{~g}$ caffeine: $\mathrm{CHO}$ (fructose/glucose) drink.

\subsubsection{Subjective Outcomes}

The facilitative effect of combined caffeine and $\mathrm{CHO}$ intake on a number of subjective state/mood indices is supported by the studies shown in Table 5. The positive effects of caffeine and glucose on 'mental energy' (the perception of mental alertness, high mood and motivation levels [107] has been reported [177,184]. Similarly, caffeine and glucose intake has been demonstrated to increase feelings of stimulation [176], alertness [184] and arousal [178]. Reduced mental effort during prolonged driving [183] and reduced mental fatigue [176] have also been reported. The level of cognitive demand/stress has been highlighted as a potential mediating factor in the relationship between caffeine and glucose, and subjective state. Subjective stress and anxiety after fire-fighting training exposure was attenuated by a $40 \mathrm{mg}: 50 \mathrm{~g}$ caffeine:glucose drink [185]. Both a $46 \mathrm{mg}: 68 \mathrm{~g}$ and a $33 \mathrm{mg}: 60 \mathrm{~g}$ caffeine:glucose drink reduced subjective fatigue during an prolonged high demand cognitive test battery [180]. These studies suggest the facilitative effects of caffeine and CHO in combination may be particularly relevant in contexts characterized by high cognitive or physical demand. The role of familiarity with the caffeine and $\mathrm{CHO}$ vehicle has also been highlighted [184]. Participants were exposed to a familiar (branded) and a novel energy drink (containing $30 \mathrm{mg}: 54 \mathrm{~g}$ caffeine:glucose) and a caffeine and $\mathrm{CHO}$-free matched version of both drinks. Upon first exposure, the familiar energy drink and its branded placebo increased alertness and mental energy compared to the novel placebo suggesting an effect of familiarity with the branded drink. Facilitative effects were evident upon the second exposure only in the drinks containing caffeine and glucose; a facilitative effect of the novel caffeine and glucose drink emerging presumably as familiarity increased.

\subsection{Interactive Effects of Caffeine and $\mathrm{CHO}$}

Evidence from studies comparing the effects of caffeine and glucose combined with caffeine- and $\mathrm{CHO}$-free placebo drinks presents a consistent and convincing case for the facilitative potential of these drinks across a range of cognitive domains and subjective measures of experience. However, a major limitation of the studies summarized in Table 5 is the failure to compare the combined effects of caffeine and $\mathrm{CHO}$ relative to the effects of these nutrients when administered in isolation. The common administration of a placebo (caffeine- and CHO-free) drink or glucose alone means it is not possible to clearly dissociate the individual and interactive effects of caffeine and $\mathrm{CHO}$ intake. It is therefore difficult to ascertain if the administration of caffeine in combination with $\mathrm{CHO}$ will proffer enhancing effects above and beyond those offered by caffeine or $\mathrm{CHO}$ intake in isolation. A number of the studies reported in Table 5 also administered commercial energy drinks which additionally contain potentially active agents (e.g., taurine, glucoronolactone, and vitamins) which may contribute/moderate the 
observed facilitative effects. Table 6 summarizes seven studies that have appropriately administered a combined caffeine and CHO dose and equivalent caffeine and glucose doses in isolation. Furthermore, a number of studies adequately controlled for additional ingredients that are commonly added to commercial energy drinks. Such designs provide some support for the facilitative effect of caffeine and $\mathrm{CHO}$ combined by demonstrating interactive effects of these nutrients in combination that are quantitatively or qualitatively different from the effects of caffeine or $\mathrm{CHO}$ administered in isolation.

\subsubsection{Cognitive Performance Outcomes}

Two of the six studies that examined performance on attention tasks reported interactive effects of caffeine and $\mathrm{CHO}$ independent of the effects of these nutrients in isolation. Scholey and Kennedy [190] administered $75 \mathrm{mg}$ caffeine, $37.5 \mathrm{~g}$ glucose and $12.5 \mathrm{mg}$ of herb mix (ginseng and ginkgo biloba) in combination and isolation, as well as a placebo drink. Only the combination of ingredients improved attention speed relative to the placebo drink. Adan and Serra-Grabulosa [191] reported a facilitative effects of $75 \mathrm{mg}: 75 \mathrm{~g}$ caffeine:glucose on a sequential RT attentional task which was not demonstrated following intake of caffeine and glucose in isolation. Serra-Grabulosa et al. [192] reported that the same combined dose decreased neural (blood-oxygen-level dependent; BOLD) activation in areas of the prefrontal cortex associated with sustained attention processes (vs. placebo), which suggests enhanced efficiency of the attentional system. However, this effect must be treated with caution as no objective, interactive behavioral effects were demonstrated. Four studies failed to demonstrate interactive effects of caffeine and glucose (caffeine:glucose: $75 \mathrm{mg}: 75 \mathrm{~g}$ [192]; $200 \mathrm{mg}: 50 \mathrm{~g}$ [193]; $80 \mathrm{mg}: 39 \mathrm{~g}$ [194]; $200 \mathrm{mg}: 50 \mathrm{~g}$ [195]). The addition of 50g CHO (white bread) to a $200 \mathrm{mg}$ caffeine capsule counteracted enhanced performance on a vigilance task compared to caffeine administered in isolation [195]. Additionally, the facilitative effects of caffeine in isolation [193], or irrespective of vehicle [194,195], on attentional performance were demonstrated.

Three of the five studies examining the effects of caffeine and $\mathrm{CHO}$ on memory domains reported positive interactive effects. Scholey and Kennedy [190] demonstrated that a $75 \mathrm{mg}$ caffeine, $37.5 \mathrm{~g}$ glucose and $12.5 \mathrm{mg}$ of herb mix drink improved secondary memory (composite scores across a number of immediate and delayed word and picture recall and recognition measures), but no effects on 'speed of memory' (composite RTs of memory tasks) or working memory. Similarly, Adan and Serra-Grabulosa et al. [191] reported an enhanced verbal learning and consolidation effect after a combined $75 \mathrm{mg}: 75 \mathrm{~g}$ caffeine:glucose drink not demonstrated by administration of caffeine and glucose alone. Finally, $200 \mathrm{mg}$ and caffeine and $50 \mathrm{~g}$ glucose increased object working memory [193]. Two studies reported no interactive effects on memory (caffeine:glucose: $200 \mathrm{mg}: 37.5 \mathrm{~g}$ [178]; $80 \mathrm{mg}: 37.5 \mathrm{~g}$ [194]). Analogous to the facilitative effects on attentional performance, caffeine in isolation was also shown to enhance memory performance. For example, Giles et al. [193] reported caffeine (200 $\mathrm{mg}$ ) to be the most consistent in the enhancement of all cognitive measures assessed, including working memory. Young and Benton [194] demonstrated that caffeine, irrespective of vehicle (yoghurt, glucose and water) enhanced memory performance (episodic and working memory).

Two studies administering $75 \mathrm{mg}$ caffeine with $37.5 \mathrm{~g}$ glucose (composite simple and attentional RT performance [190]) and 75 g glucose (sequential RT performance [191]) reported greater RT enhancement than either substance administered alone. However, caffeine alone/irrespective of vehicle improved simple [191,193], choice [193,194], and working memory [194] RT, and was reported to be the main driver of improved simple RT [178], in a number of studies. Further, the enhancing effect of $80 \mathrm{mg}$ of caffeine administered in water on RT +90 and +150 min after intake was ameliorated when this dose of caffeine was taken with glucose (37.5 g) and a yoghurt drink (3.6 glycemic load [194]). Glucose in isolation was demonstrated to both enhance simple RT and manual dexterity [191], and impair choice RT performance [193]. The selective effects of taurine were also demonstrated with impaired RT performance at low cognitive demand (simple RT) and enhanced performance at high cognitive demand (working memory RT [193]). 
Table 6. Summary of studies examining the effects of caffeine and $\mathrm{CHO}$ in combination and isolation on cognitive performance and subjective mood.

\begin{tabular}{|c|c|c|c|c|c|c|c|}
\hline Author & $\begin{array}{l}\text { Sample } \\
\text { Size (Age) }\end{array}$ & $\begin{array}{l}\text { Design } \\
\text { (Within or } \\
\text { Between } \\
\text { Subjects) }\end{array}$ & $\begin{array}{l}\text { Performance } \\
\text { Measured } \\
\text { (Relative to } \\
\text { Drink Intake) }\end{array}$ & Drink [Volume/Vehicle] & Outcome Measures & Outcomes & $\begin{array}{l}\text { Interactive } \\
\text { Effect of } \\
\text { Caffeine } \\
\text { and Glucose }\end{array}$ \\
\hline $\begin{array}{l}\text { Smit et al. } \\
2004[178]\end{array}$ & $\begin{array}{l}\text { Study 2: } 146 \\
\quad(18-54)\end{array}$ & $\begin{array}{l}\text { Between } \\
\text { (overnight } \\
\text { caffeine abstinence) }\end{array}$ & $+5-+90 \mathrm{~min}$ & $\begin{array}{c}75 \mathrm{mg} \text { caffeine }+37.5 \mathrm{~g} \text { glucose vs. } \\
37.5 \mathrm{~g} \text { glucose vs. } 75 \mathrm{mg} \text { caffeine vs. } \\
75 \mathrm{mg} \text { caffeine }+37.5 \mathrm{~g} \text { glucose } \\
\text { non-carbonated }\end{array}$ & $\begin{array}{l}\text { Simple RT; RVIP; immediate and } \\
\text { delayed word recall; letter search } \\
\text { task; mood VAS }\end{array}$ & $\begin{array}{c}\text { Main treatment effect suggesting caffeine = } \\
\text { main component associated with improved } \\
\text { simple RT and increased arousal; } \\
\text { comparatively minor, weak effects of } \\
\text { CHO demonstrated }\end{array}$ & $\mathrm{x}$ \\
\hline $\begin{array}{l}\text { Scholey \& } \\
\text { Kennedy, } \\
2004[190]\end{array}$ & $20(18-32)$ & $\begin{array}{l}\text { Within (overnight } \\
\text { fast; morning } \\
\text { coffee abstinence) }\end{array}$ & $+30 \mathrm{~min}$ & $\begin{array}{l}(250 \mathrm{~mL}) \text { Placebo (artificially flavored } \\
\text { and sweetened water vehicle) vs. } \\
\text { vehicle }+75 \mathrm{mg} \text { caffeine vs. vehicle }+ \\
37.5 \mathrm{~g} \text { glucose vs. vehicle + flavoring } \\
\text { levels of herbs ( } 12.5 \mathrm{mg} \text { ginseng } \\
\text { extract and } 2.004 \mathrm{mg} \text { ginkgo biloba } \\
\text { extract) vs. complete energy drink } \\
\text { ( } 75 \mathrm{mg} \text { caffeine, } 37.5 \mathrm{~g} \text { glucose }+ \\
\text { flavoring levels of herbs) }\end{array}$ & $\begin{array}{c}\text { CBG; HR; Digit Symbol Substitution } \\
\text { Task; CDR (immediate and delayed } \\
\text { word + picture recall and recognition; } \\
\text { Simple and choice RT; digit vigilance; } \\
\text { spatial and numeric WM. Factor } \\
\text { analyzed for global "quality of } \\
\text { memory" outcomes; Bond-Lader } \\
\text { mood VAS; POMS }\end{array}$ & $\begin{array}{l}\text { No effect of glucose/caffeine/herbs in } \\
\text { isolation. Whole drink = improved "Secondary } \\
\text { memory" (combined \% accuracy scores } \\
\text { delayed word recognition, delayed picture } \\
\text { recognition, immediate word recall and } \\
\text { delayed word recall) and "speed of attention" } \\
\text { performance vs. placebo (only) }\end{array}$ & $\sqrt{ }$ \\
\hline $\begin{array}{l}\text { Maridakis et al. } \\
2009 \text { [195] }\end{array}$ & $17(M=23.8)$ & Within ( $8 \mathrm{~h}$ fast) & $\sim+30 \mathrm{~min}$ & $\begin{array}{l}\text { (Capsule) } 200 \mathrm{mg} \text { caffeine }+50 \mathrm{~g} \\
\text { CHO (white bread) vs. } 200 \mathrm{mg} \\
\text { caffeine vs. } 50 \mathrm{~g} \text { CHO vs. placebo } \\
\text { capsule vs. } 50 \mathrm{~g} \text { CHO + placebo pill }\end{array}$ & $\begin{array}{c}\text { CPT; BAKAN; POMS; } \\
\text { Activation-Deactivation Checklist; } \\
\text { State-Trait Energy and Fatigue scales }\end{array}$ & $\begin{array}{l}\text { Caffeine improved attention. No additional } \\
\text { performance benefit of adding CHO. Caffeine } \\
\text { increase energy, lowered fatigue. No } \\
\text { additional benefit of adding CHO. CHO in } \\
\text { isolation = less effects on mood }\end{array}$ & $x$ \\
\hline $\begin{array}{l}\text { Adan \& } \\
\text { Serra-Grabulosa, } \\
2010[191]\end{array}$ & $72(18-25)$ & $\begin{array}{l}\text { Between }(8 \mathrm{~h} \text { fast; } \\
18 \mathrm{~h} \text { caffeine } \\
\text { abstinence) }\end{array}$ & $+30 \mathrm{~min}$ & $\begin{array}{l}(150 \mathrm{~mL}) \text { water vs. water }+75 \mathrm{mg} \\
\text { caffeine vs. water }+75 \mathrm{~g} \text { glucose vs. } \\
\text { water }+75 \mathrm{mg} \text { caffeine } / 75 \mathrm{~g} \text { glucose }\end{array}$ & $\begin{array}{l}\text { CBG; salivary caffeine level; RAVLT; } \\
\text { Purdue-Pegboard; Benton Judgement } \\
\text { of Line Orientation Test } \\
\text { (visuo-spatial function); CCAP } \\
\text { (attention, RT and visual scanning } \\
\text { speed); digit span; mood VAS }\end{array}$ & $\begin{array}{l}\text { Caffeine }+ \text { glucose }=\text { beneficial effects on } \\
\text { attention (sequential RT tasks) and verbal } \\
\text { memory learning and consolidation (not } \\
\text { shown by ingredients in isolation). Caffeine } \\
\text { alone = improved simple RT. Glucose alone = } \\
\text { improved simple and sequential RT tasks and } \\
\text { manual dexterity assembly task. }\end{array}$ & $\sqrt{ }$ \\
\hline $\begin{array}{l}\text { Serra-Grabulosa } \\
\text { et al. } \\
2010 \text { [192] }\end{array}$ & $40(18-25)$ & $\begin{array}{l}\text { Between ( } 8 \mathrm{~h} \text { fast; } \\
12 \mathrm{~h} \\
\text { caffeine abstinence) }\end{array}$ & $+30 \mathrm{~min}$ & $\begin{array}{l}(150 \mathrm{~mL}) \text { Water }+75 \mathrm{~g} \text { glucose vs. } \\
\text { water }+75 \mathrm{mg} \text { caffeine vs. water }+ \\
75 \mathrm{~g} \text { glucose } / 75 \mathrm{mg} \text { caffeine }\end{array}$ & $\begin{array}{l}\text { CBG; salivary caffeine level; CPT } \\
\text { (sustained attention); fMRI }\end{array}$ & $\begin{array}{l}\text { No effect of drink on cognitive performance. } \\
\text { Glucose + caffeine = decreased activation in } \\
\text { the bilateral parietal and left prefrontal cortex } \\
\text { (areas associated with sustained attention and } \\
\text { WM processes). Interpreted as increased } \\
\text { efficiency of the attentional system }\end{array}$ & $\sqrt{ }$ \\
\hline
\end{tabular}


Table 6. Cont.

\begin{tabular}{|c|c|c|c|c|c|c|c|}
\hline Author & $\begin{array}{c}\text { Sample } \\
\text { Size (Age) }\end{array}$ & $\begin{array}{l}\text { Design } \\
\text { (Within or } \\
\text { Between } \\
\text { Subjects) }\end{array}$ & $\begin{array}{l}\text { Performance } \\
\text { Measured } \\
\text { (Relative to } \\
\text { Drink Intake) } \\
\end{array}$ & Drink [Volume/Vehicle] & Outcome Measures & Outcomes & $\begin{array}{l}\text { Interactive } \\
\text { Effect of } \\
\text { Caffeine } \\
\text { and Glucose }\end{array}$ \\
\hline $\begin{array}{l}\text { Giles et al. } \\
2012 \text { [193] }\end{array}$ & $48(M=20.08)$ & $\begin{array}{l}\text { Mixed } \\
\text { (standardized } \\
\text { meal }+2 \mathrm{~h} \text { fast; } \\
24 \mathrm{~h} \text { caffeine } \\
\text { abstinence) }\end{array}$ & $\begin{array}{l}+30 \min (\mathrm{WM}) \\
+60 \min (\mathrm{RT})\end{array}$ & $\begin{array}{l}\text { (Capsule) Within (all P's): } 200 \mathrm{mg} \\
\text { caffeine } / 0 \mathrm{mg} \text { taurine vs. } 0 \mathrm{mg} \\
\text { caffeine } / 2000 \mathrm{mg} \text { taurine vs. } 200 \mathrm{mg} \\
\text { caffeine } / 2000 \mathrm{mg} \text { taurine vs. } 0 \mathrm{mg} \\
\text { caffeine } / 0 \mathrm{mg} \text { taurine; [ }[500 \mathrm{~mL} \text { ] } \\
\text { Between }(50: 50 \text { sample split) } 50 \mathrm{~g} \\
\text { glucose vs. } 50 \mathrm{~g} \text { stevia }\end{array}$ & $\begin{array}{l}\text { HR; Attention network test (alerting, } \\
\text { orienting, executive control); N-back } \\
\text { task; simple and choice RT; salivary } \\
\text { cortisol; POMS }\end{array}$ & $\begin{array}{c}\text { Caffeine = most consistent effects on cognitive } \\
\text { performance. Glucose slowed RT. } \\
\text { Glucose }+ \text { caffeine enhanced object WM. } \\
\text { Glucose + taurine, enhanced orienting } \\
\text { attention. Taurine = selective effects (+ive at } \\
\text { high load). Caffeine reduced headache } \\
\text { symptoms and tiredness and increased } \\
\text { alertness. Caffeine reduced fatigue and } \\
\text { increased feelings of tension and vigor. } \\
\text { Glucose potentiated caffeine-induced feelings } \\
\text { of tension. Taurine intake opposed caffeine } \\
\text { effects on mood }\end{array}$ & $x$ \\
\hline $\begin{array}{l}\text { Young \& } \\
\text { Benton } \\
2013 \text { [194] }\end{array}$ & $345(M=21.78)$ & Between ( $2 \mathrm{~h}$ fast) & $+30 ;+90 ;+150 \mathrm{~min}$ & $\begin{array}{l}(250 \mathrm{~mL}) \text { yoghurt }(\mathrm{GL}=3.6)+\text { no } \\
\text { caffeine vs. yoghurt }(\mathrm{GL}=3.6)+ \\
80 \mathrm{mg} \text { caffeine vs. } 39 \mathrm{~g} \text { glucose } \\
(\mathrm{GL}=30)+\text { no caffeine vs. } 39 \mathrm{~g} \\
\text { glucose }(\mathrm{GL}=30)+80 \mathrm{mg} \text { caffeine } \\
\text { vs. flavored water }+ \text { no caffeine vs. } \\
\text { flavored water }+80 \mathrm{mg} \text { caffeine }\end{array}$ & $\begin{array}{l}\text { CBG and CGMS (subsample } n=38 \text { ); } \\
\text { immediate and delayed word recall; } \\
\text { choice RT; serial sevens; arrow } \\
\text { flankers (selective attention); } \\
\text { vigilance/sustained attention; POMS }\end{array}$ & $\begin{array}{l}\text { Caffeine, irrespective of vehicle, = better } \\
\text { memory, faster RT (choice reaction time test } \\
\text { and WM) and increased vigilance. Greater } \\
\text { subjective energy reported } 30 \text { min after } \\
\text { consuming caffeine and water, vs. water alone; } \\
\text { after } 90 \text { and } 150 \text { min caffeine administered in } \\
\text { water increased tiredness, hostility and } \\
\text { confusion. Combining caffeine with a } \\
\text { yoghurt-based drink increased energy, } \\
\text { agreeableness and clear-headedness later in } \\
\text { the morning. No effects of caffeine + glucose } \\
\text { on mood }\end{array}$ & $x$ \\
\hline
\end{tabular}

x—effect; $\sqrt{ }$ —no effect; GL—glycemic load; WM—working memory; CBG—capillary blood glucose; HR—heart rate; POMS—Profile of Mood States; CGMS—continuous glucose monitoring system; CPT—continuous performance task. 
Controversy exists in caffeine literature regards whether the beneficial effects of caffeine intake on performance represents a genuine facilitative effect or alleviation of the impairing effects of caffeine withdrawal [196,197]. The majority of studies reviewed included a period of caffeine abstinence in the study design. Most studies adopted an abstinence period between $\sim 6$ and $24 \mathrm{~h}$. Only one study specifically considered the confounding effects of caffeine withdrawal and imposed a $1 \mathrm{~h}$ abstinence period [173]. Positive effects of caffeine and glucose $(80 \mathrm{mg}: 26 \mathrm{~g})$ on attention and verbal reasoning were reported in the absence of caffeine withdrawal. James and Rogers [197] argue that many of the net effects of caffeine supplementation may be as a result of reversal of adverse withdrawal effects following short-term abstinence. Placebo-controlled studies with relatively short periods of abstinence ( 1-24 h.) have predominated in the examination of the effects of caffeine and glucose. Alternative study designs may be more appropriate to examine the role of caffeine withdrawal on cognitive and subjective outcomes. Indeed, James and Rogers [197] propose that long-term withdrawal studies are the only valid method of assessing the effects of caffeine.

\subsubsection{Subjective Outcomes}

The studies summarized in Table 6 permit clearer characterization of the capacity of caffeine and $\mathrm{CHO}$ combined or isolation to moderate subjective mood. Confirmatory evidence for the interactive effects of caffeine and glucose providing facilitative effects above and beyond the effects these nutrients in isolation is weak. Only Young and Benton [194] reported that the combination of $80 \mathrm{mg}$ caffeine and with a low glycemic load yoghurt vehicle drink counteracted the negative mood effects of caffeine administered in water (tiredness, hostility and confusion). However, no effects of caffeine combined with a $39 \mathrm{~g}$ glucose load were reported suggesting a key role of glycemic load moderating the action of caffeine. Giles et al. [193] reported that adding $50 \mathrm{~g}$ of glucose (to $200 \mathrm{mg}$ caffeine) actually potentiated caffeine-induced feelings of subjective tension. Caffeine in isolation was also shown to reduce headaches, tiredness, fatigue, and increase alertness, tension and vigor. Such effects are likely due to the elevation of caffeine withdrawal symptoms in this $24 \mathrm{~h}$ caffeine deprived sample. The addition of taurine to the caffeine load opposed these effects of caffeine on mood. The remaining studies that measured subjective states reported no subjective effects of caffeine and CHO intake $[190,191,195]$.

\subsection{Summary of Interactive Effects}

The evidence for a specific synergistic effect of caffeine and $\mathrm{CHO}$ combined has received some support from studies examining these nutrients combined and in isolation. The facilitative effects of caffeine on attention are well known. Two studies have shown attentional facilitation, in excess of caffeine intake, by combining caffeine with glucose $[190,191]$, and reduced activation in neural areas associated with attentional processes [192]. This suggests combined administration offers performance enhancement beyond that offered by caffeine and glucose in isolation. However, an effect of caffeine in isolation was also reported $[193,194]$. This inconsistency may be as a result of the discrepant attentional tasks employed. Studies demonstrating interactive effects employed a composite attentional performance score, which may be more a sensitive measure of performance [190], or placed a high level of demand on attentional resources [191]. Similarly, a specific enhancement of RT following intake of caffeine and glucose is reported for high demand tasks $[190,191]$. Caffeine in isolation was mostly associated with improved RT on low demand tasks (e.g., [191,193]). This suggests a specific performance facilitation effect for caffeine combined with glucose in high demand contexts. However, caffeine and glucose in combination also reduced RT [194]. The most consistent evidence for interactive effects is shown in relation to memory. Three studies have demonstrated specific facilitation of episodic $[190,191]$ and working memory [193] only when caffeine and glucose were combined. However, specific effects of caffeine alone on memory have also been reported using the same episodic memory task and comparable caffeine:glucose dose (caffeine:glucose: $75 \mathrm{mg}: 37.5 \mathrm{~g}$ [190] vs. $80 \mathrm{mg}: 39 \mathrm{~g}$ [194]) suggesting additional, as yet unknown, moderating variables may explain the discrepancies in the evidence. 
The psychostimulant effects of caffeine and $\mathrm{CHO}$ has been supported by evidence of increased subjective stimulation [176], alertness [184], arousal [178], mental fatigue [171,176], mental effort [183], and mental energy $[177,178]$. However, the majority of this evidence is from studies that did not duly administer caffeine and glucose in isolation (Table 5). To date, the evidence for interactive facilitative effects of caffeine and CHO on subjective states is weak, and in combination, may even worsen mood compared to administration in isolation.

\subsection{Dose Effects}

\subsubsection{Cognitive Performance Outcomes}

Figure 1 summarizes enhanced or impaired cognitive performance outcomes as a function of caffeine and $\mathrm{CHO}$ content. This is representative of all studies reviewed and includes multiple outcomes reported from single studies. The majority of the facilitative effects of caffeine and $\mathrm{CHO}$ on attention have been reported after intake of 33-46 mg caffeine and 54-68 g CHO. Positive attentional effects have also been demonstrated with higher caffeine:low CHO doses (80 mg:26 g caffeine:glucose and $200 \mathrm{mg}: 26 \mathrm{~g}$ caffeine:glucose + taurine). However, a high caffeine dose combined with a comparatively higher $\mathrm{CHO}$ dose $(50 \mathrm{mg}$ ) counteracted performance facilitation of caffeine alone. In this instance, the addition of $\mathrm{CHO}$ removed the enhancing effect of caffeine administered in isolation. Reaction time facilitation has been demonstrated across a wider range of caffeine and $\mathrm{CHO}$ doses but enhanced performance is not reported below a $75 \mathrm{mg}$ dose of caffeine. Indeed, RT was impaired in the sleep deprived following intake of $30 \mathrm{mg}$ of caffeine (with $42 \mathrm{~g} \mathrm{CHO} \mathrm{[181]).} \mathrm{Howard} \mathrm{and} \mathrm{Marczinski} \mathrm{[176]} \mathrm{report} \mathrm{a} \mathrm{caffeine} \mathrm{dose}$ effect on behavioral control RT in which performance was enhanced following lower doses of caffeine $(1.8 \mathrm{mg} / \mathrm{kg}=45.6 \mathrm{mg}$ for an average $78 \mathrm{~kg}$ participant), and diminished as caffeine dose increased ( 3.6 and $5.4 \mathrm{mg} / \mathrm{kg}$ ). This suggests the enhancing effect of a lower caffeine dose may require specific dose calculation based on body weight. A maximal caffeine dose at which facilitation of RT occurs is not evident. For example, a $200 \mathrm{mg}$ dose (combined with $375 \mathrm{~g}$ dextrose) enhanced simple choice RT [177]. A $275 \mathrm{mg}$ caffeine dose coffee, a combined $80 \mathrm{mg}$ caffeine and $\mathrm{CHO}$ energy drink (CHO dose not stated), and the coffee and energy drink administered together (delivering a total of $365 \mathrm{mg}$ caffeine) have been shown to enhance a number of indices of RT performance [174]. However, whilst all the drinks delivered significant facilitative effects, the effects sizes were greater for the vehicles delivering the lower dose of caffeine (i.e., caffeine and energy drink in isolation).

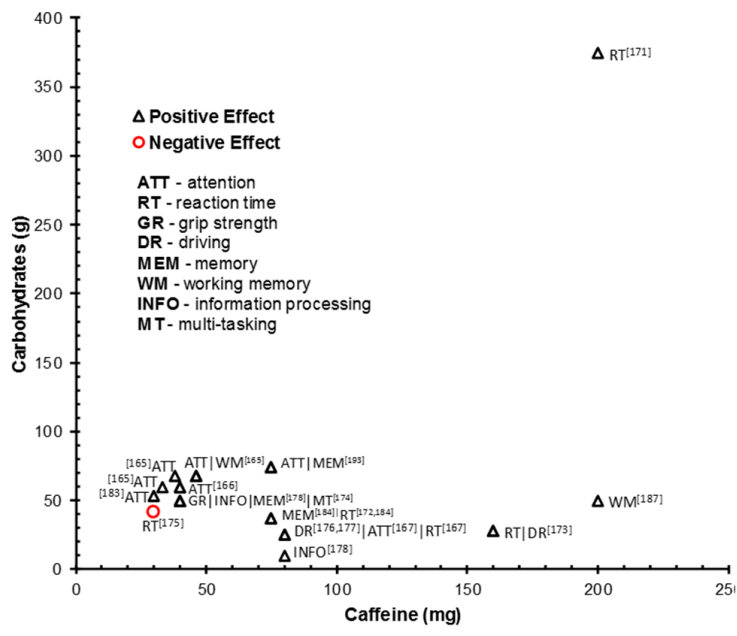

Figure 1. Scatterplot of cognitive performance outcomes (enhanced or impaired) by caffeine and $\mathrm{CHO}$ drink content. Data are representative of all studies reviewed and include multiple outcomes reported by single studies. Howard and Marczinski [176] not shown due to caffeine/CHO being administered based on body weight. Aniţei et al. [174] not shown as do not state $\mathrm{CHO}$ dose. 
The lowest reported dose of CHOs combined with caffeine $(75 \mathrm{mg}$ ) to facilitate RT performance is $37.5 \mathrm{~g}$. No effects on RT performance were demonstrated when a $\sim 27 \mathrm{~g}$ glucose/sucrose blend was administered with a comparable dose of caffeine (80 $\mathrm{mg}$ [175]). This suggests a minimum CHO dose $>27$ g-37.5 g may be required for the enhancement of RT when combined with caffeine. A maximal dose of $\mathrm{CHO}$ at which facilitation of RT occurs is not evident. A $375 \mathrm{~g}$ dextrose dose (combined with $200 \mathrm{mg}$ caffeine) has been shown to improve RT in sleep deprived individuals.

Enhanced driving performance has been demonstrated with a fairly consistent dose of $\mathrm{CHO}$ (26-28.25 g) combined with $80 \mathrm{mg}$ and $160 \mathrm{mg}$ of caffeine. However, the interactive effect of caffeine and glucose combined and in isolation has yet to be examined. Working memory has been enhanced with a high caffeine dose (200 $\mathrm{mg}$ ) combined with $50 \mathrm{~g}$ of glucose [193]. No consistent moderation of working memory performance by lower doses of caffeine (75 mg) and lower and higher glucose loads (37.5 g and $75 \mathrm{~g}$ ) suggests a dose caffeine dose effect. However, Kennedy and Scholey [171] reported a short-lived improvement in working memory performance with $46 \mathrm{mg}: 68 \mathrm{~g}$ caffeine:glucose. Furthermore, $80 \mathrm{mg}$ dose of caffeine was sufficient to enhance working memory RT performance irrespective of whether administered in a glucose and yoghurt drinks, or water [194]. No obvious dose effect was evident for facilitation of episodic memory despite the same task being administered (immediate and delayed word recall and recognition). Both $40 \mathrm{mg}$ and $75 \mathrm{mg}$ of caffeine combined with (50 $\mathrm{g}$ and $37.5 \mathrm{~g}$ of glucose respectively) were sufficient to enhance performance. Conversely, no effects were demonstrated with $80 \mathrm{mg}$ and $30 \mathrm{mg}$ caffeine administered with 10.25-54 g of CHO. Sünram-Lea et al. [185] suggest the ratio of caffeine to glucose may be important. Only a high glucose (50 mg):low caffeine (40 mg), and not a low CHO (10.25 g fructose/glucose):high caffeine (80 mg), drink enhanced episodic memory. However, this finding may be specific to the stressful and physically demanding context employed. Hand grip strength was similarly selectively enhanced by the high glucose, low caffeine drink in this study. No such selective effects of caffeine to glucose ratio were observed for information processing which was enhanced by both ratio drinks. Further, $80 \mathrm{mg}$ of caffeine alone may be sufficient to enhance episodic memory [194].

\subsubsection{Subjective Outcomes}

Figure 2 summarizes enhanced or impaired subjective outcomes as a function of caffeine and $\mathrm{CHO}$ content. This is representative of all studies reviewed and includes multiple outcomes reported from single studies. The capacity for caffeine and $\mathrm{CHO}$ administration to increase energetic arousal was demonstrated with 30-200 mg of caffeine administered with comparable doses of CHO (37.5-54 g) enhancing mental energy, alertness and arousal. However, a $200 \mathrm{mg}: 50 \mathrm{~g}$ caffeine:glucose also drink increased subjective tension [193] or provided no additional effects than caffeine administered in isolation (200 mg capsule + bread [195]). This variability in the data may be due to the diverse and often arbitrary measures of subjective state employed. Alternatively, individual differences may result in some participants experiencing the increased arousal as positive (e.g., mental energy), and others, as negative (e.g., tension).

High caffeine ( $80 \mathrm{mg})$ :low $\mathrm{CHO}$ (26 g) ratio drinks have been demonstrated to reduce subjective sleepiness and mental effort in the context of prolonged driving. This facilitation may be specific to this ratio since lower doses of caffeine $(30 \mathrm{mg})$ combined double the $\mathrm{CHO}(54 \mathrm{~g})$ does not counteract sleepiness in the same context. However, comparable low caffeine (33 mg and $46 \mathrm{mg}$ ):high glucose (68 $\mathrm{g}$ and $60 \mathrm{~g}$ ) drinks reduce subjective mental fatigue. Once again, this discrepancy may more likely reflect the diverse measures of subjective experience and the variable definitions of subjective state (sleepiness vs. mental fatigue) rather than a specific dose effect per se.

The ratio of caffeine to glucose may be important in contexts of high physical and cognitive demand. Selective facilitative effects of $40 \mathrm{mg}: 50 \mathrm{~g}$ glucose on reduced subjective stress and anxiety have been demonstrated; facilitation was not evident after intake of a $80 \mathrm{mg}: 10.25 \mathrm{~g}$ caffeine: $\mathrm{CHO}$ drink [185]. 


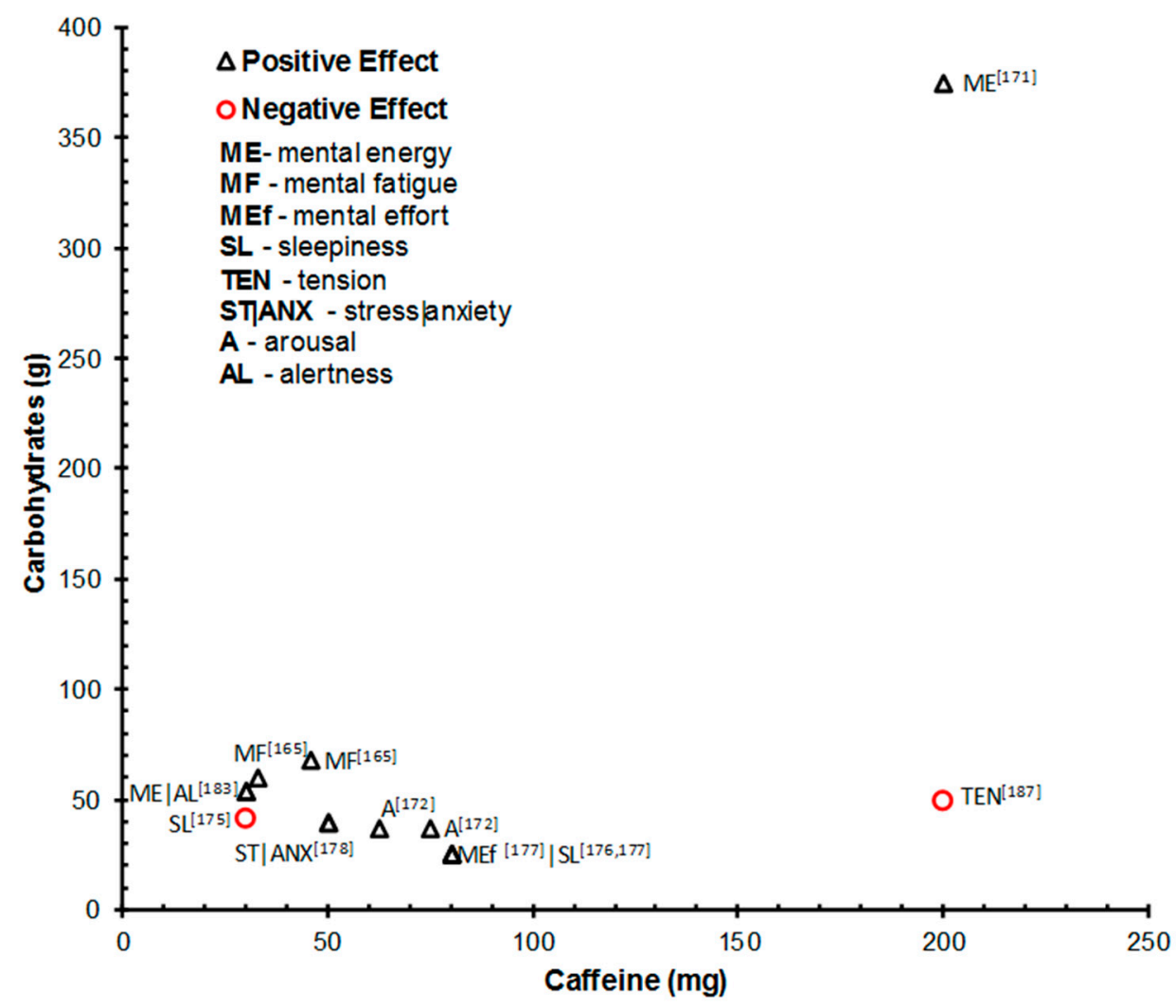

Figure 2. Scatterplot of subjective outcomes (enhanced or impaired) by caffeine and CHO drink content. Data are representative of all studies reviewed and include multiple outcomes reported by single studies. Howard and Marczinski [176] not shown due to caffeine/CHO being administered based on body weight. Aniţei et al. [174] not shown as do not state $\mathrm{CHO}$ dose.

\subsection{Mechanisms of Action}

Caffeine increases local cerebral glucose consumption [198]. Therefore, a reductive explanation is simply that the augmentation of blood glucose increases the localized effect of caffeine via increased cerebral glucose consumption. A related potential metabolic mechanism is the altered absorption and pharmacokinetic profiles of caffeine and $\mathrm{CHO}$ when administered concurrently. Caffeine administered in isolation increases blood glucose levels via the impairment of glucose tolerance and decreased insulin sensitivity $[199,200]$. The administration of caffeine with a glucose load has the potential to alter the glycemic profile of the drink. Studies that measured the post-ingestive glycemic response provide support for this proposition. Young and Benton [194] reported that $80 \mathrm{mg}$ of caffeine administered with 39 g glucose or a low GL (3.6) yoghurt drink increased interstitial glucose levels, delaying peak response by $10 \mathrm{~min}$ and prolonging an elevated response over $90 \mathrm{~min}$. post-drink, compared to these vehicles administered without caffeine. These authors also highlight the importance of considering the vehicle in which caffeine is administered and the timescale in which outcomes are assessed. No consistent effects of caffeine or glucose combined or in isolation on subjective energy levels were reported in the short term ( $+30 \mathrm{~min}$. post intake). However, administration of caffeine alone resulted in greater tiredness in the longer term (+90 and +150 min.), whereas, administration of caffeine in a low GL yoghurt vehicle resulted in greater subjective energy over the same period.

The potential for glucose to alter caffeine absorption has also been demonstrated. Adan and Serra-Grabulosa [191] and Serra-Grabulosa et al. [192] reported that whilst caffeine alone did not moderate glucose response, salivary caffeine levels were lower when $75 \mathrm{mg}$ of caffeine was administered with $75 \mathrm{~g}$ glucose compared to caffeine administered alone. This suggests that glucose may act to slow down the absorption of caffeine or accelerate its removal from circulation. 
The action of caffeine and glucose on neurotransmitter function is another potential mechanism of the facilitative effects of these nutrients. Increased cholinergic activity has been associated with enhanced cognitive attentional and memory performance [201-203]. Caffeine can provoke the up-regulation of cholinergic activity via the blocking of adenosine receptors $[150,204]$. Further, glucose is a substrate of acetylcholine synthesis which is proposed to underpin its enhancing effects on cognitive performance $[98,205]$. Therefore, caffeine and glucose may proffer facilitative benefits via action on cholinergic function. Further, the effect of combining these nutrients may result in a greater increase cholinergic activity, proffering greater facilitative benefit, than that of administering caffeine and glucose in isolation. The potential moderation of neurotransmitter function by caffeine and glucose is far from limited to cholinergic activity [206]. Furthermore, the facilitative effects of caffeine and glucose are unlikely to be mediated by any one mechanism, rather by a synergy of metabolic, neurotransmitter and neuro-hormonal action [190].

Two studies reported the impairing effect of glucose and caffeine combined. Anderson and Horne [181] reported the slowing of RT (80 min post consumption) and trend for increased overall sleepiness after consuming a $30 \mathrm{mg}: 42 \mathrm{~g}$ caffeine:CHO drink in sleep restricted individuals. The authors emphasize that ingestion of high levels of glucose might have a short acting alerting effect, but over longer periods of time may enhance sleepiness, and thus reduce cognitive performance, in people already sleepy. This is suggestive of a specific post-prandial impairing effect of glucose, likely underpinned by rapid increase and subsequent decrease in blood glucose levels. Further, the low dose of caffeine administered may have been insufficient to counteract any fatiguing effect of glucose. However, such explanations are speculative as the authors did not compare the effect of combined caffeine and glucose with these nutrients in isolation. These findings were also only demonstrated by trend and are specific to a sleep deprived context. Giles et al. [193] did compare the combined vs. isolated effects of caffeine and glucose. Combining glucose with caffeine potentiated subjective ratings of tension. One explanation of this additive negative effect may be the augmentation of blood glucose magnified the localized effect of this high dose of caffeine $(200 \mathrm{mg})$ via increased cerebral glucose consumption.

\subsection{Unanswered Questions and Recommendations for Future Research}

\subsubsection{Interactive Effects}

More studies examining the effects of caffeine and $\mathrm{CHO}$ in combination and isolation are required since there are currently only seven studies to have done so. Further, only three studies report specific positive effects of combining caffeine and $\mathrm{CHO}$ in excess of these nutrients in isolation. Studies should also examine the different effects of dose/ratio of caffeine: $\mathrm{CHO}$ to evaluate the dose-dependent enhancement effects on cognitive performance and mood as well as the contribution of each nutrient in isolation. The existing evidence of facilitative effects of caffeine and $\mathrm{CHO}$ drinks includes studies which have examined the effects of energy drinks. The relative contribution of additional ingredients often added to these commercial caffeine and $\mathrm{CHO}$ drinks needs to be systematically examined. For example, taurine has been demonstrated to moderate the effects of caffeine and glucose on cognitive and subjective outcomes [193]. Further, the effects of the ingredients contained in specific energy drinks may result in multiple, systemic, and tissue-specific effects.

\subsubsection{Timescale of Effect}

The majority of studies examining the effects of caffeine and $\mathrm{CHO}$ have examined outcomes during the temporal peak of caffeine and glucose responses (0-60 min). Many of the studies delayed the onset of cognitive test batteries until $+30 \mathrm{~min}$. to ensure adequate absorption of the combined nutrients. However, whilst plasma levels peak within an hour, caffeine has a half-life of 5-6 h in healthy adults [207]. The longer-term effects of caffeine and CHO consumption have largely been ignored. Considering evidence of the altered absorption and pharmacokinetic profiles of caffeine and 
$\mathrm{CHO}$ when administered together, facilitative, or indeed impairing, effects may be more prominent over more prolonged timescales. Further, the evidence to date is reflective of the effect of acute dosing and should not be extrapolated to the effects of chronic intake of caffeine and $\mathrm{CHO}$. Whilst consistent physical performance and glucose tolerance effects are shown over chronic use [208], resistance to the physiological [209] and behavioral [210] effects following chronic intake of caffeine have been demonstrated. The proposed enhancing effect of caffeine being as a result of a reduction in the symptoms of caffeine withdrawal also necessitates longer-term study designs to confirm or refute this potential confounder in the relationship between caffeine and glucose supplementation and performance facilitation.

\subsubsection{Vehicle of Administration}

Further research is needed to establish the effects of caffeine relative to the vehicle in which it is administered. The majority of studies have employed high GL or water-based vehicles to administer caffeine. Young and Benton [194] have demonstrated the importance of considering the vehicle/diet in which caffeine is administered and the timescale in which outcome are assessed. For example, manipulation of glycemic load of drinks can moderate subsequent effects on performance and mood over a longer timescale than the normal plasma caffeine peak. For example, traditional energy drinks combine caffeine with a high GL load (predominantly glucose). Drinks with high GL may negatively affect performance and mood 2-3 h after consumption, whereas, a low GL drinks that slowly raises blood glucose may maintain performance and mood over longer periods. Additional vehicle factors that may affect the action of caffeine and glucose include carbonation which can change the rate at which the stomach is emptied [211], thus potentially altering the rate at which nutrients are absorbed.

It is important to note that whilst caffeine can enhance cognitive performance, it is also associated with impaired glucose tolerance and insulin sensitivity [212,213], both of which have been associated with impaired cognition in the longer term.

\subsubsection{Effects on Subjective States}

Characterization of the potential for caffeine and glucose to moderated subjective states is hampered by the diverse methods used to objectively measure subjective experience. In behavioral sciences, measures of cognitive behavior (e.g., reaction time, number of words recalled) and physiological variables (e.g., salivary cortisol concentration, blood pressure, heart rate variability) are considered to be objective measures, in contrast to, self-rating/self-reported measures of, for example, mood, which is often referred to as subjective measures. Mood can be described as a pervasive and predominant affective state and is commonly conceived to vary along orthogonal and bipolar dimensions of valence (positive vs. negative) and arousal/activation (e.g., [214,215]). Mood can also be temporally separated into protracted (e.g., depressed mood) and transient, fluctuating affective states (e.g., a momentary state of increased vigor). As mood is inherently phenomenological, it is perceived as an inconsistent measure of the brain's output [216]. This is reflected in the common rejection of claims related to nutrients proffering benefits to subjective states, such as 'mental energy', which are not sufficiently characterized and have in the main not received favorable opinions from EFSA.

Some attempts have been made to clarify the validity and reliability of subjective measures of subjective state in relation to caffeine and CHO. Maridakis et al. [195] compared three measures of subjective energy and fatigue. Whilst all measures were sensitive to caffeine manipulation, some were more sensitive than others for specific aspects of subjective state (e.g., fatigue: VAS more sensitive than POMS). The inclusion of multiple measures of subjective state in nutrient manipulation studies will permit further clarification of the subjective effects of interventions and increase the construct validity of claims related to any observed changes in subjective state. 


\section{Conclusions}

The potential facilitative effects of $\mathrm{CHOs}$ on cognitive performance have now been examined for six decades and remains a prototypical research model of the nutrition-behavior axis. The dose of glucose for which the most consistent effects on cognitive function have been observed is $25 \mathrm{~g}$. These have predominantly been studies of episodic memory. Indeed, the often-quoted optimal facilitative dose of $25 \mathrm{~g}$ may be specific to this domain and certainly moderated by additional factors (e.g., task load, glucoregulatory control). There is a distinct lack of studies which systematically vary the dose of glucose to determine the facilitative dose response effect for cognitive domains other than episodic memory. Therefore, failure to observe robust facilitation on certain cognitive tasks may simply be due to suboptimal dosing. Further research is needed to fully differentiate between the response profiles of glucose administration for different cognitive domains. Dose-response studies of other $\mathrm{CHOs}$ are also required.

There is currently insufficient evidence to suggest that increasing the complexity of $\mathrm{CHOs}$, or the selection of a vehicle of administration, to manipulate the glycemic response has a consistent cognitive performance benefit. Further research is needed to fully elucidate if GL manipulations offer any facilitative benefit. This should be examined across multiple cognitive domains.

Caffeine combined with glucose has been demonstrated to facilitate cognitive performance and subjective mood compared to placebo and glucose alone. However, the relative contribution of each ingredient is not ascertainable in the majority of studies. To date there have been only 7 studies which have appropriately compared the effects of caffeine and glucose alone, and in combination. Further examination of the contribution of each nutrient in isolation is required, as well as systematic manipulation of the dose/ratio of caffeine: $\mathrm{CHO}$, to evaluate if there exist any dose-dependent enhancement effects on cognitive performance and mood. Studies which measure beyond the immediate absorption phase of caffeine and glucose are also needed since the half-life of caffeine is 5-6 h, and depending on the vehicle, glucose can reach the bloodstream much more rapidly (in min. rather than hours). The temporal impact of glucose and caffeine has not been clearly documented and the behavioral effects of these in dose response studies are unknown. Despite a large body of research on each constituent, the totality of the evidence is unclear since studies have not been undertaken in a systematic manner with a specific and common hypothesis. In the light of health recommendations, it is also important to consider the likely findings of longer term studies which are lacking from the literature. There have been no chronic or repeated studies of caffeine and glucose in combination and it may be important to investigate effects over the longer term particularly in the light of the evidence that caffeine increases glycemic response.

Acknowledgments: The assistance of Siobhan Mitchell in the preparation of this manuscript is gratefully acknowledged. The authors received funding from PepsiCo for completion of this manuscript. The funder played no role in the selection of papers for review and provided only editing and proof reading assistance in the preparation of this manuscript.

Author Contributions: N.B.B., L.D. and C.L.L. all contributed to the formulation and writing of this review.

Conflicts of Interest: The authors declare no conflicts of interest.

\section{References}

1. Hafermann, G. Schulmüdigkeit und Blutzuckerverhalten. Öffentl. Gesundh. 1955, 17, 11-17.

2. Bellisle, F.; Blundell, J.E.; Dye, L.; Fantino, M.; Fern, E.; Fletcher, R.J.; Lambert, J.; Roberfoid, M.; Specter, S.; Westenhofer, J.; et al. Functional food science and behaviour and psychological functions. Br. J. Nutr. 1998, 80, S173-S193. [CrossRef] [PubMed]

3. Dye, L.; Blundell, J. Functional foods: Psychological and behavioural functions. Br. J. Nutr. 2002, 88, S187-S211. [CrossRef] [PubMed]

4. Sünram-Lea, S.-I.; Owen, L.; Robertson, B. Glycaemic control and cognition: Evidence across the lifespan. In Nutrition for Brain Health and Cognitive Performance; Dye, T.B.L., Ed.; CRC Press-Taylor \& Francis Group: Boca Raton, FL, USA, 2015; pp. 125-150. 
5. Sieber, F.E.; Traystman, R.J. Special issues-Glucose and the brain. Crit. Care Med. 1992, 20, $104-114$. [CrossRef] [PubMed]

6. Smith, M.A.; Foster, J.K. The impact of a high versus a low glycaemic index breakfast cereal meal on verbal episodic memory in healthy adolescents. Nutr. Neurosci. 2008, 11, 219-227. [CrossRef] [PubMed]

7. Foster, J.K.; Lidder, P.G.; Sunram, S.I. Glucose and memory: Fractionation of enhancement effects? Psychopharmacology (Berlin) 1998, 137, 259-270. [CrossRef]

8. Riby, L.M.; Law, A.S.; McLaughlin, J.; Murray, J. Preliminary evidence that glucose ingestion facilitates prospective memory performance. Nutr. Res. (N. Y.) 2011, 31, 370-377. [CrossRef] [PubMed]

9. Riby, L.M.; Meikle, A.; Glover, C. The effects of age, glucose ingestion and gluco-regulatory control on episodic memory. Age Ageing 2004, 33, 483-487. [CrossRef] [PubMed]

10. Riby, L.M.; Marriott, A.; Bullock, R.; Hancock, J.; Smallwood, J.; McLaughlin, J. The effects of glucose ingestion and glucose regulation on memory performance in older adults with mild cognitive impairment. Eur. J. Clin. Nutr. 2009, 63, 566-571. [CrossRef] [PubMed]

11. Manning, C.A.; Ragozzino, M.E.; Gold, P.E. Glucose enhancement of memory in patients with probable senile dementia of the alzheimers type. Neurobiol. Aging 1993, 14, 523-528. [CrossRef]

12. Brandt, K.R. Effects of glucose administration on category exclusion recognition. J. Psychopharmacol. 2015, 29, 777-782. [CrossRef] [PubMed]

13. Owen, L.; Scholey, A.; Finnegan, Y.; Suenram-Lea, S.I. Response variability to glucose facilitation of cognitive enhancement. Br. J. Nutr. 2013, 110, 1873-1884. [CrossRef] [PubMed]

14. Sunram-Lea, S.; Brandt, K. Effect of glucose ingestion on recognition memory for emotionally arousing stimuli. Int. J. Psychol. 2008, 43, 224.

15. Sunram-Lea, S.I.; Foster, J.K.; Durlach, P.; Perez, C. Investigation into the significance of task difficulty and divided allocation of resources on the glucose memory facilitation effect. Psychopharmacology (Berlin) 2002, 160, 387-397. [CrossRef] [PubMed]

16. Sunram-Lea, S.I.; Owen, L.; Finnegan, Y.; Hu, H.L. Dose-response investigation into glucose facilitation of memory performance and mood in healthy young adults. J. Psychopharmacol. 2011, 25, 1076-1087. [CrossRef] [PubMed]

17. Sunram-Lea, S.I.; Foster, J.K.; Durlach, P.; Perez, C. Glucose facilitation of cognitive performance in healthy young adults: Examination of the influence of fast-duration, time of day and pre-consumption plasma glucose levels. Psychopharmacology (Berlin) 2001, 157, 46-54. [CrossRef]

18. Sunram-Lea, S.I.; Foster, J.K.; Durlach, P.; Perez, C. The effect of retrograde and anterograde glucose administration on memory performance in healthy young adults. Behav. Brain Res. 134, 505-516. [CrossRef]

19. Mohanty, A.; Flint, R.W., Jr. Differential effects of glucose on modulation of emotional and nonemotional spatial memory tasks. Cogn. Affect. Behav. Neurosci. 2001, 1, 90-95. [CrossRef] [PubMed]

20. Scholey, A.B.; Fowles, K.A. Retrograde enhancement of kinesthetic memory by alcohol and by glucose. Neurobiol. Learn. Mem. 2002, 78, 477-483. [CrossRef] [PubMed]

21. Owens, D.S.; Benton, D. The impact of raising blood-glucose on reaction-times. Neuropsychobiology 1994, 30, 106-113. [CrossRef] [PubMed]

22. Hall, J.L.; Gonderfrederick, L.A.; Chewning, W.W.; Silveira, J.; Gold, P.E. Glucose enhancement of performance on memory tests in young and aged humans. Neuropsychologia 1989, 27, 1129-1138. [CrossRef]

23. Kennedy, D.O.; Scholey, A.B. Glucose administration, heart rate and cognitive performance: Effects of increasing mental effort. Psychopharmacology (Berlin) 2000, 149, 63-71. [CrossRef]

24. Miller, H.C.; Bourrasseau, C.; Blampain, J. Can you enhance executive control without glucose? The effects of fructose on problem solving. J. Psychopharmacol. 2013, 27, 645-650. [CrossRef] [PubMed]

25. Jones, E.K.; Sunram-Lea, S.I.; Wesnes, K.A. Acute ingestion of different macronutrients differentially enhances aspects of memory and attention in healthy young adults. Biol. Psychol. 2012, 89, 477-486. [CrossRef] [PubMed]

26. Meikle, A.; Riby, L.M.; Stollery, B. The impact of glucose ingestion and gluco-regulatory control on cognitive performance: A comparison of younger and middle aged adults. Hum. Psychopharmacol.-Clin. Exp. 2004, 19, 523-535. [CrossRef] [PubMed]

27. Reay, J.L.; Kennedy, D.O.; Scholey, A.B. Effects of panax ginseng, consumed with and without glucose, on blood glucose levels and cognitive performance during sustained 'mentally demanding' tasks. J. Psychopharmacol. 2006, 20, 771-781. [CrossRef] [PubMed] 
28. Stollery, B.; Christian, L. Glucose and memory: The influence of drink, expectancy, and beliefs. Psychopharmacology (Berlin) 2013, 228, 685-697. [CrossRef] [PubMed]

29. Azari, N.P. Effects of glucose on memory processes in young-adults. Psychopharmacology (Berlin) 1991, 105, 521-524. [CrossRef]

30. Benton, D.; Owens, D.S. Blood-glucose and human-memory. Psychopharmacology (Berlin) 1993, 113, 83-88. [CrossRef]

31. Manning, C.A.; Parsons, M.W.; Cotter, E.M.; Gold, P.E. Glucose effects on declarative and nondeclarative memory in healthy elderly and young adults. Psychobiology 1997, 25, 103-108.

32. Winder, R.; Borrill, J. Fuels for memory: The role of oxygen and glucose in memory enhancement. Psychopharmacology (Berlin) 1998, 136, 349-356. [CrossRef]

33. Benton, D. The impact of increasing blood-glucose on psychological functioning. Biol. Psychol. 1990, 30, 13-19. [CrossRef]

34. Craft, S.; Murphy, C.; Wemstrom, J. Glucose effects on complex memory and nonmemory tasks-The influence of age, sex, and glucoregulatory response. Psychobiology 1994, 22, 95-105.

35. Benton, D.; Owens, D.S.; Parker, P.Y. Blood-glucose influences memory and attention in young-adults. Neuropsychologia 1994, 32, 595-607. [CrossRef]

36. Parker, P.Y.; Benton, D. Blood-glucose levels selectively influence memory for word lists dichotically presented to the right ear. Neuropsychologia 1995, 33, 843-854. [CrossRef]

37. Messier, C.; Pierre, J.; Desrochers, A.; Gravel, M. Dose-dependent action of glucose on memory processes in women: Effect on serial position and recall priority. Cogn. Brain Res. 1998, 7, 221-233. [CrossRef]

38. Messier, C.; Desrochers, A.; Gagnon, M. Effect of glucose, glucose regulation, and word imagery value on human memory. Behav. Neurosci. 1999, 113, 431-438. [CrossRef] [PubMed]

39. Donohoe, R.T.; Benton, D.C. Cognitive functioning is susceptible to the level of blood glucose. Psychopharmacology 1999, 145, 378-385. [CrossRef] [PubMed]

40. Metzger, M.M. Glucose enhancement of a facial recognition task in young adults. Physiol. Behav. 2000, 68, 549-553. [CrossRef]

41. Green, M.W.; Taylor, M.A.; Elliman, N.A.; Rhodes, O. Placebo expectancy effects in the relationship between glucose and cognition. Br. J. Nutr. 2001, 86, 173-179. [CrossRef] [PubMed]

42. Morris, N.; Sarll, P. Drinking glucose improves listening span in students who miss breakfast. Educ. Res. 2001, 43, 201-207. [CrossRef]

43. Scholey, A.B.; Harper, S.; Kennedy, D.O. Cognitive demand and blood glucose. Physiol. Behav. 2001, 73, 585-592. [CrossRef]

44. Awad, N.; Gagnon, M.; Desrochers, A.; Tsiakas, M.; Messier, C. Impact of peripheral glucoregulation on memory. Behav. Neurosci. 2002, 116, 691-702. [CrossRef] [PubMed]

45. Ford, C.E.; Scholey, A.B.; Ayre, G.; Wesnes, K. The effect of glucose administration and the emotional content of words on heart rate and memory. J. Psychopharmacol. 2002, 16, 241-244. [CrossRef] [PubMed]

46. Flint, R.W.; Turek, C. Glucose effects on a continuous performance test of attention in adults. Behav. Brain Res. 2003, 142, 217-228. [CrossRef]

47. Meikle, A.; Riby, L.M.; Stollery, B. Memory processing and the glucose facilitation effect: The effects of stimulus difficulty and memory load. Nutr. Neurosci. 2005, 8, 227-232. [CrossRef] [PubMed]

48. Riby, L.M.; McMurtrie, H.; Smallwood, J.; Ballantyne, C.; Meikle, A.; Smith, E. The facilitative effects of glucose ingestion on memory retrieval in younger and older adults: Is task difficulty or task domain critical? Br. J. Nutr. 2006, 95, 414-420. [CrossRef] [PubMed]

49. Brandt, K.R.; Sunram-Lea, S.I.; Qualtrough, K. The effect of glucose administration on the emotional enhancement effect in recognition memory. Biol. Psychol. 2006, 73, 199-208. [CrossRef] [PubMed]

50. Gailliot, M.T.; Baumeister, R.F. The physiology of willpower: Linking blood glucose to self-control. Pers. Soc. Psychol. Rev. 2007, 11, 303-327. [CrossRef] [PubMed]

51. Masicampo, E.J.; Baumeister, R.F. Toward a physiology of dual-process reasoning and judgment-Lemonade, willpower, and expensive rule-based analysis. Psychol. Sci. 2008, 19, 255-260. [CrossRef] [PubMed]

52. DeWall, C.N.; Baumeister, R.F.; Gailliot, M.T.; Maner, J.K. Depletion makes the heart grow less helpful: Helping as a function of self-regulatory energy and genetic relatedness. Personal. Soc. Psychol. Bull. 2008, 34, 1653-1662. [CrossRef] [PubMed] 
53. Morris, N. Elevating blood glucose level increases the retention of information from a public safety video. Biol. Psychol. 2008, 78, 188-190. [CrossRef] [PubMed]

54. Riby, L.M.; McLaughlin, J.; Riby, D.M. Lifestyle, glucose regulation and the cognitive effects of glucose load in middle-aged adults. Br. J. Nutr. 2008, 100, 1128-1134. [CrossRef] [PubMed]

55. Scholey, A.B.; Sunram-Lea, S.I.; Greer, J.; Elliott, J.; Kennedy, D.O. Glucose administration prior to a divided attention task improves tracking performance but not word recognition: Evidence against differential memory enhancement? Psychopharmacology (Berlin) 2009, 202, 549-558. [CrossRef] [PubMed]

56. Scholey, A.B.; Sunram-Lea, S.I.; Greer, J.; Elliott, J.; Kennedy, D.O. Glucose enhancement of memory depends on initial thirst. Appetite 2009, 53, 426-429. [CrossRef] [PubMed]

57. Owen, L.; Finnegan, Y.; Hu, H.; Scholey, A.B.; Suenram-Lea, S.I. Glucose effects on long-term memory performance: Duration and domain specificity. Psychopharmacology (Berlin) 2010, 211, 131-140. [CrossRef] [PubMed]

58. Brandt, K.R.; Sunram-Lea, S.I.; Jenkinson, P.M.; Jones, E. The effects of glucose dose and dual-task performance on memory for emotional material. Behav. Brain Res. 2010, 211, 83-88. [CrossRef] [PubMed]

59. Parent, M.B.; Krebs-Kraft, D.L.; Ryan, J.P.; Wilson, J.S.; Harenski, C.; Hamann, S. Glucose administration enhances fmri brain activation and connectivity related to episodic memory encoding for neutral and emotional stimuli. Neuropsychologia 2011, 49, 1052-1066. [CrossRef] [PubMed]

60. Smith, E.; Hay, P.; Campbell, L.; Trollor, J.N. A review of the association between obesity and cognitive function across the lifespan: Implications for novel approaches to prevention and treatment. Obes. Rev. 2011, 12, 740-755. [CrossRef] [PubMed]

61. Brandt, K.R.; Gibson, E.L.; Rackie, J.M. Differential facilitative effects of glucose administration on stroop task conditions. Behav. Neurosci. 2013, 127, 932-935. [CrossRef] [PubMed]

62. Scholey, A.; Macpherson, H.; Suenram-Lea, S.; Elliott, J.; Stough, C.; Kennedy, D. Glucose enhancement of recognition memory: Differential effects on effortful processing but not aspects of 'remember-know' responses. Neuropharmacology 2013, 64, 544-549. [CrossRef] [PubMed]

63. Brown, L.A.; Riby, L.M. Glucose enhancement of event-related potentials associated with episodic memory and attention. Food Funct. 2013, 4, 770-776. [CrossRef] [PubMed]

64. Lange, F.; Eggert, F. Sweet delusion. Glucose drinks fail to counteract ego depletion. Appetite 2014, 75, 54-63. [CrossRef] [PubMed]

65. Stollery, B.; Christian, L. Glucose, relational memory, and the hippocampus. Psychopharmacology (Berlin) 2015, 232, 2113-2125. [CrossRef] [PubMed]

66. Macpherson, H.; Roberstson, B.; Suenram-Lea, S.; Stough, C.; Kennedy, D.; Scholey, A. Glucose administration and cognitive function: Differential effects of age and effort during a dual task paradigm in younger and older adults. Psychopharmacology (Berlin) 2015, 232, 1135-1142. [CrossRef] [PubMed]

67. Gold, P.E. Modulation of memory processing: Enhancement ofmemory in rodents and humans. In The Neuropsychology of Memory, 2nd ed.; Squire, L.R., Butters, N., Eds.; Guilford: New York, NY, USA, 1992.

68. Gold, P.E.; Vogt, J.; Hall, J.L. Glucose effects on memory-Behavioral and pharmacological characteristics. Behav. Neural Biol. 1986, 46, 145-155. [CrossRef]

69. Rodriguez, W.A.; Vanausdle, L.R.; Dhanens, K.; Mondragon, A.N. Glucose modulates recently reactivated memories. Psychobiology 1993, 21, 93-100.

70. Stone, W.S.; Walser, B.; Gold, S.D.; Gold, P.E. Scopolamine-induced and morphine-induced impairments of spontaneous-alternation performance in mice-Reversal with glucose and with cholinergic and adrenergic agonists. Behav. Neurosci. 1991, 105, 264-271. [CrossRef] [PubMed]

71. White, N.M. Peripheral and Central Memory-Enhancing Actions of Glucose; American Psychological Association: Washington, DC, USA, 1991; Volume 6, pp. 421-441.

72. Lamport, D.J.; Lawton, C.L.; Mansfield, M.W.; Moulin, C.A.J.; Dye, L. Type 2 diabetes and impaired glucose tolerance are associated with word memory source monitoring recollection deficits but not simple recognition familiarity deficits following water, low glycaemic load, and high glycaemic load breakfasts. Physiol. Behav. 2014, 124, 54-60. [CrossRef] [PubMed]

73. Parsons, M.W.; Gold, P.E. Glucose enhancement of memory in elderly humans-An inverted-u dose-response curve. Neurobiol. Aging 1992, 13, 401-404. [CrossRef] 
74. Hoyland, A.; Lawton, C.L.; Dye, L. Acute effects of macronutrient manipulations on cognitive test performance in healthy young adults: A systematic research review. Neurosci. Biobehav. Rev. 2008, 32, 72-85. [CrossRef] [PubMed]

75. Messier, C. Glucose improvement of memory: A review. Eur. J. Pharmacol. 2004, 490, 33-57. [CrossRef] [PubMed]

76. Gold, S.M.; Dziobek, I.; Rogers, K.; Bayoumy, A.; McHugh, P.F.; Convit, A. Hypertension and hypothalamo-pituitary-adrenal axis hyperactivity affect frontal lobe integrity. J. Clin. Endocrinol. Metab. 2005, 90, 3262-3267. [CrossRef] [PubMed]

77. Li, S.C.; Lindenberger, U.; Hommel, B.; Aschersleben, G.; Prinz, W.; Baltes, P.B. Transformations in the couplings among intellectual abilities and constituent cognitive processes across the life span. Psychol. Sci. 2004, 15, 155-163. [CrossRef] [PubMed]

78. Benton, D.; Parker, P.Y.; Donohue, R.T. The supply of glucose to the brain and cognitive functioning. J. Biosoc. Sci. 1997, 28, 463-479.

79. McNay, E.C.; Fries, T.M.; Gold, P.E. Decreases in rat extracellular hippocampal glucose concentration associated with cognitive demand during a spatial task. Proc. Natl. Acad. Sci. USA 2000, 97, 2881-2885. [CrossRef] [PubMed]

80. Fairclough, S.H.; Houston, K. A metabolic measure of mental effort. Biol. Psychol. 2004, 66, 177-190. [CrossRef] [PubMed]

81. Gailliot, M.T.; Baumeister, R.F.; DeWall, C.N.; Maner, J.K.; Plant, E.A.; Tice, D.M.; Brewer, L.E.; Schmeichel, B.J Self-control relies on glucose as a limited energy source: Willpower is more than a metaphor. J. Personal. Soc. Psychol. 2007, 92, 325-336. [CrossRef] [PubMed]

82. Inzlicht, M.; Schmeichel, B.J. What is ego depletion? Toward a mechanistic revision of the resource model of self-control. Perspect. Psychol. Sci. 2012, 7, 450-463. [CrossRef] [PubMed]

83. Muraven, M.; Baumeister, R. Self-regulation and depletion of limited resources: Does self-control resemble a muscle? Psychol. Bull. 2000, 126, 247-259. [CrossRef] [PubMed]

84. Hagger, M.S.; Chatzisarantis, N.L.D. The sweet taste of success: The presence of glucose in the oral cavity moderates the depletion of self-control resources. Personal. Soc. Psychol. Bull. 2013, 39, 28-42. [CrossRef] [PubMed]

85. Kurzban, R. Does the brain consume additional glucose during self-control tasks? Evol. Psychol. 2010, 8, 244-259. [CrossRef] [PubMed]

86. Sanders, M.; Shirk, S.; Burgin, C.; Martin, L. The gargle effect rinsing the mouth with glucose enhances self-control. Psychol. Sci. 2012, 23, 1470-1472. [CrossRef] [PubMed]

87. Carter, J.M.; Jeukendrup, A.E.; Jones, D.A. The effect of carbohydrate mouth rinse on 1-h cycle time trial performance. Med. Sci. Sports Exerc. 2004, 36, 2107-2111. [CrossRef] [PubMed]

88. Chambers, E.; Bridge, M.; Jones, D. Carbohydrate sensing in the human mouth: Effects on exercise performance and brain activity. J. Physiol. 2009, 587, 1779-1794. [CrossRef] [PubMed]

89. Pottier, A.; Bouckaert, J.; Gilis, W.; Roels, T.; Derave, W. Mouth rinse but not ingestion of a carbohydrate solution improves 1-h cycle time trial performance. Scand. J. Med. Sci. Sports 2010, 20, 105-111. [CrossRef] [PubMed]

90. Kringelbach, M.L. Food for thought: Hedonic experience beyond homeostasis in the human brain. Neuroscience 2004, 126, 807-819. [CrossRef] [PubMed]

91. Molden, D.C.; Hui, C.M.; Scholer, A.A.; Meier, B.P.; Noreen, E.E.; D'Agostino, P.R.; Martin, V. Motivational versus metabolic effects of carbohydrates on self-control. Psychol. Sci. 2012, 23, 1137-1144. [CrossRef] [PubMed]

92. Boyle, N.; Lawton, C.L.; Newens, K.; Allen, A.; Croden, F.; Smith, K.; Dye, L. The effect of ingesting and rinsing sucrose and sucralose on depleted self-control performance. Physiol. Behav. 2015, in press.

93. Convit, A. Links between cognitive impairment in insulin resistance: An explanatory model. Neurobiol. Aging 2005, 26, 31-35. [CrossRef] [PubMed]

94. Gruetter, R.; Novotny, E.J.; Boulware, S.D.; Rothman, D.L.; Shulman, R.G. $1 \mathrm{~h}$ NMR studies of glucose transport in the human brain. J. Cereb. Blood Flow Metab. 1996, 16, 427-438. [CrossRef] [PubMed]

95. Pardridge, W.M.; Triguero, D.; Farrell, C.R. Downregulation of blood-brain barrier glucose transporter in experimental diabetes. Diabetes 1990, 39, 1040-1044. [CrossRef] [PubMed] 
96. Haier, R.J.; Siegel, B.V.; Maclachlan, A.; Soderling, E.; Lottenberg, S.; Buchsbaum, M.S. Regional glucose metabolic changes after learning a complex visuospatial motor task-A positron emission tomographic study. Brain Res. 1992, 570, 134-143. [CrossRef]

97. Brands, A.M.A.; Biessels, G.J.; De Haan, E.H.F.; Kappelle, L.J.; Kessels, R.P.C. The effects of type 1 diabetes on cognitive performance-A meta-analysis. Diabetes Care 2005, 28, 726-735. [CrossRef] [PubMed]

98. Gold, P.E. Role of glucose in regulating the brain and cognition. Am. J. Clin. Nutr. 1995, 61, S987-S995. [CrossRef]

99. Greenwood, C.E.; Kaplan, R.J.; Hebblethwaite, S.; Jenkins, D.J.A. Carbohydrate-induced memory impairment in adults with type 2 diabetes. Diabetes Care 2003, 26, 1961-1966. [CrossRef] [PubMed]

100. Allen, K.V.; Frier, B.M.; Strachan, M.W.J. The relationship between type 2 diabetes and cognitive dysfunction: Longitudinal studies and their methodological limitations. Eur. J. Pharmacol. 2004, 490, 169-175. [CrossRef] [PubMed]

101. Lamport, D.J.; Lawton, C.L.; Mansfield, M.W.; Dye, L. Impairments in glucose tolerance can have a negative impact on cognitive function: A systematic research review. Neurosci. Biobehav. Rev. 2009, 33, $394-413$. [CrossRef] [PubMed]

102. Strachan, M.W.J. Insulin and cognitive function in humans: Experimental data and therapeutic considerations. Biochem. Soc. Trans. 2005, 33, 1037-1040. [CrossRef] [PubMed]

103. Hamann, S. Cognitive and neural mechanisms of emotional memory. Trends Cogn. Sci. 2001, 5, 394-400. [CrossRef]

104. Blake, T.M.; Varnhagen, C.K.; Parent, M.B. Emotionally arousing pictures increase blood glucose levels and enhance recall. Neurobiol. Learn. Mem. 2001, 75, 262-273. [CrossRef] [PubMed]

105. Parent, M.B.; Varnhagen, C.; Gold, P.E. A memory-enhancing emotionally arousing narrative increases blood glucose levels in human subjects. Psychobiology 1999, 27, 386-396.

106. Fillmore, M.; Vogelsprott, M. Expected effect of caffeine on motor-performance predicts the type of response to placebo. Psychopharmacology (Berlin) 1992, 106, 209-214. [CrossRef]

107. Gorby, H.E.; Brownawell, A.M.; Falk, M.C. Do specific dietary constituents and supplements affect mental energy? Review of the evidence. Nutr. Rev. 2010, 68, 697-718. [CrossRef] [PubMed]

108. Gailliot, M.T.; Peruche, B.M.; Plant, E.A.; Baumeister, R.F. Stereotypes and prejudice in the blood: Sucrose drinks reduce prejudice and stereotyping. J. Exp. Soc. Psychol. 2009, 45, 288-290. [CrossRef]

109. Kringelbach, M.L.; de Araujo, I.E.T.; Rolls, E.T. Taste-related activity in the human dorsolateral prefrontal cortex. Neuroimage 2004, 21, 781-788. [CrossRef] [PubMed]

110. Purnell, J.Q.; Klopfenstein, B.A.; Stevens, A.A.; Havel, P.J.; Adams, S.H.; Dunn, T.N.; Krisky, C.; Rooney, W.D. Brain functional magnetic resonance imaging response to glucose and fructose infusions in humans. Diabetes Obes. Metab. 2011, 13, 229-234. [CrossRef] [PubMed]

111. Thayer, J.F.; Hansen, A.L.; Saus-Rose, E.; Johnsen, B.H. Heart rate variability, prefrontal neural function, and cognitive performance: The neurovisceral integration perspective on self-regulation, adaptation, and health. Ann. Behav. Med. 2009, 37, 141-153. [CrossRef] [PubMed]

112. Ferguson, H.B.; Stoddart, C.; Simeon, J.G. Double-blind challenge studies of behavioral and cognitive effects of sucrose-aspartame ingestion in normal-children. Nutr. Rev. 1986, 44, 144-150. [CrossRef] [PubMed]

113. Wolraich, M.L.; Lindgren, S.D.; Stumbo, P.J.; Stegink, L.D.; Appelbaum, M.I.; Kiritsy, M.C. Effects of diets high in sucrose or aspartame on the behavior and cognitive performance of children. N. Engl. J. Med. 1994, 330, 301-307. [CrossRef] [PubMed]

114. Van der Zwaluw, N.L.; van de Rest, O.; Kessels, R.P.C.; de Groot, L. Short-term effects of glucose and sucrose on cognitive performance and mood in elderly people. J. Clin. Exp. Neuropsychol. 2014, 36, 517-527. [CrossRef] [PubMed]

115. Harte, C.B.; Kanarek, R.B. The effects of nicotine and sucrose on spatial memory and attention. Nutr. Neurosci. 2004, 7, 121-125. [CrossRef] [PubMed]

116. Dye, L.; Gilsenan, M.B.; Quadt, F.; Martens, V.E.G.; Bot, A.; Lasikiewiczi, N.; Camidge, D.; Croden, F.; Lawton, C. Manipulation of glycemic response with isomaltulose in a milk-based drink does not affect cognitive performance in healthy adults. Mol. Nutr. Food Res. 2010, 54, 506-515. [CrossRef] [PubMed]

117. Kashimura, J.; Nagai, Y.; Ebashi, T. The effect of palatinose on mental concentration in humans. J. Nutr. Sci. Vitaminol. (Tokyo) 2003, 49, 214-216. [CrossRef] [PubMed] 
118. Lina, B.A.R.; Jonker, D.; Kozianowski, G. Isomaltulose (palatinose ${ }^{\circledR}$ ): A review of biological and toxicological studies. Food Chem. Toxicol. 2002, 40, 1375-1381. [CrossRef]

119. Holub, I.; Gostner, A.; Theis, S.; Nosek, L.; Kudlich, T.; Melcher, R.; Scheppach, W. Novel findings on the metabolic effects of the low glycaemic carbohydrate isomaltulose (palatinose ${ }^{\mathrm{TM}}$ ). Br. J. Nutr. 2010, 103, 1730-1737. [CrossRef] [PubMed]

120. Kawai, K.; Okuda, Y.; Yamashita, K. Changes in blood glucose and insulin after an oral palatinose administration in normal subjects. Endocrinol. Jpn. 1985, 32, 933-936. [CrossRef] [PubMed]

121. Arai, H.; Mizuno, A.; Sakuma, M.; Fukaya, M.; Matsuo, K.; Muto, K.; Sasaki, H.; Matsuura, M.; Okumura, H.; Yamamoto, H.; et al. Effects of a palatinose-based liquid diet (inslow) on glycemic control and the second-meal effect in healthy men. Metabolism 2007, 56, 115-121. [CrossRef] [PubMed]

122. Sekartini, R.; Wiguna, T.; Bardosono, S.; Novita, D.; Arsianti, T.; Calame, W.; Schaafsma, A. The effect of lactose-isomaltulose-containing growing-up milks on cognitive performance of Indonesian children: A cross-over study. Br. J. Nutr. 2013, 110, 1089-1097. [CrossRef] [PubMed]

123. Taib, M.N.M.; Shariff, Z.M.; Wesnes, K.A.; Abu Saad, H.; Sariman, S. The effect of high lactose-isomaltulose on cognitive performance of young children. A double blind cross-over design study. Appetite 2012, 58, 81-87. [CrossRef] [PubMed]

124. Young, H.; Benton, D. The effect of using isomaltulose (palatinose) to modulate the glycaemic properties of breakfast on the cognitive performance of children. Eur. J. Nutr. 2015, 54, 1013-1020. [CrossRef] [PubMed]

125. Brouns, F.; Bjorck, I.; Frayn, K.N.; Gibbs, A.L.; Lang, V.; Slama, G.; Wolever, T.M.S. Glycaemic index methodology. Nutr. Res. Rev. 2005, 18, 145-171. [CrossRef] [PubMed]

126. Gilsenan, M.B.; de Bruin, E.A.; Dye, L. The influence of carbohydrate on cognitive performance: A critical evaluation from the perspective of glycaemic load. Br. J. Nutr. 2009, 101, 941-949. [CrossRef] [PubMed]

127. Brand-Miller, J.C.; Thomas, M.; Swan, V.; Ahmad, Z.I.; Petocz, P.; Colagiuri, S. Physiological validation of the concept of glycemic load in lean young adults. J. Nutr. 2003, 133, 2728-2732. [CrossRef] [PubMed]

128. Blaak, E.E.; Antoine, J.M.; Benton, D.; Bjorck, I.; Bozzetto, L.; Brouns, F.; Diamant, M.; Dye, L.; Hulshof, T.; Holst, J.J.; et al. Impact of postprandial glycaemia on health and prevention of disease. Obes. Rev. 2012, 13, 923-984. [CrossRef] [PubMed]

129. Amiel, S.A. Cognitive function testing in studies of acute hypoglycaemia: Rights and wrongs? Diabetologia 1998, 41, 713-719. [CrossRef] [PubMed]

130. Fischer, K.; Colombani, P.C.; Langhans, W.; Wenk, C. Cognitive performance and its relationship with postprandial metabolic changes after ingestion of different macronutrients in the morning. Br. J. Nutr. 2001, 85, 393-405. [CrossRef] [PubMed]

131. Fischer, K.; Colombani, P.C.; Langhans, W.; Wenk, C. Carbohydrate to protein ratio in food and cognitive performance in the morning. Physiol. Behav. 2002, 75, 411-423. [CrossRef]

132. Nilsson, A.C.; Ostman, E.M.; Granfeldt, Y.; Bjorck, I.M.E. Effect of cereal test breakfasts differing in glycemic index and content of indigestible carbohydrates on daylong glucose tolerance in healthy subjects. Am. J. Clin. Nutr. 2008, 87, 645-654. [PubMed]

133. Ingwersen, J.; Defeyter, M.A.; Kennedy, D.O.; Wesnes, K.A.; Scholey, A.B. A low glycaemic index breakfast cereal preferentially prevents children's cognitive performance from declining throughout the morning. Appetite 2007, 49, 240-244. [CrossRef] [PubMed]

134. Wesnes, K.A.; Pincock, C.; Richardson, D.; Helm, G.; Hails, S. Breakfast reduces declines in attention and memory over the morning in schoolchildren. Appetite 2003, 41, 329-331. [CrossRef] [PubMed]

135. Micha, R.; Rogers, P.J.; Nelson, M. The glycaemic potency of breakfast and cognitive function in school children. Eur. J. Clin. Nutr. 2010, 64, 948-957. [CrossRef] [PubMed]

136. Benton, D.; Nabb, S. Breakfasts that release glucose at different speeds interact with previous alcohol intake to influence cognition and mood before and after lunch. Behav. Neurosci. 2004, 118, 936-943. [CrossRef] [PubMed]

137. Benton, D.; Ruffin, M.P.; Lassel, T.; Nabb, S.; Messaoudi, M.; Vinoy, S.; Desor, D.; Lang, V. The delivery rate of dietary carbohydrates affects cognitive performance in both rats and humans. Psychopharmacology (Berlin) 2003, 166, 86-90. [CrossRef] [PubMed]

138. Nabb, S.; Benton, D. The influence on cognition of the interaction between the macro-nutrient content of breakfast and glucose tolerance. Physiol. Behav. 2006a, 87, 16-23. [CrossRef] [PubMed] 
139. Nabb, S.L.; Benton, D. The effect of the interaction between glucose tolerance and breakfasts varying in carbohydrate and fibre on mood and cognition. Nutr. Neurosci. 2006b, 9, 161-168. [CrossRef] [PubMed]

140. Brennan, C.S. Dietary fibre, glycaemic response, and diabetes. Mol. Nutr. Food Res. 2005, 49, 560-570. [CrossRef] [PubMed]

141. Krishnan, M.; Prabhasankar, P. Health based pasta: Redefining the concept of the next generation convenience food. Crit. Rev. Food Sci. Nutr. 2011, 52, 9-20. [CrossRef] [PubMed]

142. Dammann, K.W.; Bell, M.; Kanter, M.; Berger, A. Effects of consumption of sucromalt, a slowly digestible carbohydrate, on mental and physical energy questionnaire responses. Nutr. Neurosci. 2013, 16, 83-95. [CrossRef] [PubMed]

143. Granfeldt, Y.; Nyberg, L.; Bjorck, I. Muesli with 4 g oat [beta]-glucans lowers glucose and insulin responses after a bread meal in healthy subjects. Eur. J. Clin. Nutr. 2007, 62, 600-607. [CrossRef] [PubMed]

144. Anderson, J.W.; Allgood, L.D.; Turner, J.; Oeltgen, P.R.; Daggy, B.P. Effects of psyllium on glucose and serum lipid responses in men with type 2 diabetes and hypercholesterolemia. Am. J. Clin. Nutr. 1999, 70, 466-473. [PubMed]

145. Nilsson, M.; Holst, J.J.; Björck, I.M. Metabolic effects of amino acid mixtures and whey protein in healthy subjects: Studies using glucose-equivalent drinks. Am. J. Clin. Nutr. 2007, 85, 996-1004. [PubMed]

146. Nilsson, M.; Stenberg, M.; Frid, A.; Holst, J.; Bjorck, I. Glycemia and insulinemia in healthy subjects after lactose-equivalent meals of milk and other food proteins: The role of plasma amino acids and incretins. Am. J. Clin. Nutr. 2004, 80, 1246-1253. [CrossRef] [PubMed]

147. Petersen, B.; Ward, L.; Bastian, E.; Jenkins, A.; Campbell, J.; Vuksan, V. A whey protein supplement decreases post-prandial glycemia. Nutr. J. 2009, 8, 47. [CrossRef] [PubMed]

148. Gunnerud, U.J.; Ostman, E.M.; Bjorck, I.M.E. Effects of whey proteins on glycaemia and insulinaemia to an oral glucose load in healthy adults; a dose-response study. Eur. J. Clin. Nutr. 2013, 67, 749-753. [CrossRef] [PubMed]

149. Sunram-Lea, S.I.; Foster, J.K.; Durlach, P.; Perez, C. The influence of fat co-administration on the glucose memory facilitation effect. Nutr. Neurosci. 2004, 7, 21-32. [CrossRef] [PubMed]

150. Nehlig, A.; Daval, J.L.; Debry, G. Caffeine and the central-nervous-system-Mechanisms of action, biochemical, metabolic and psychostimulant effects. Brain Res. Rev. 1992, 17, 139-169. [CrossRef]

151. Kamimori, G.H.; Johnson, D.; Thorne, D.; Belenky, G. Multiple caffeine doses maintain vigilance during early morning operations. Aviat. Space Environ. Med. 2005, 76, 1046-1050. [PubMed]

152. Spaeth, A.M.; Goel, N.; Dinges, D.F. Cumulative neurobehavioral and physiological effects of chronic caffeine intake: Individual differences and implications for the use of caffeinated energy products. Nutr. Rev. 2014, 72, 34-47. [CrossRef] [PubMed]

153. Scharff, J.L.; Broida, J.P.; Conway, K.; Yue, A. The interaction of parental alcoholism, adaptation role, and familial dysfunction. Addict. Behav. 2004, 29, 575-581. [CrossRef] [PubMed]

154. Benowitz, N.L. Clinical-pharmacology of caffeine. Annu. Rev. Med. 1990, 41, 277-288. [CrossRef] [PubMed]

155. Glade, M.J. Caffeine-not just a stimulant. Nutrition 2010, 26, 932-938. [CrossRef] [PubMed]

156. Rogers, P.J.; Dernoncourt, C. Regular caffeine consumption: A balance of adverse and beneficial effects for mood and psychomotor performance. Pharmacol. Biochem. Behav. 1998, 59, 1039-1045. [CrossRef]

157. Smith, A. Effects of caffeine on human behavior. Food Chem. Toxicol. 2002, 40, 1243-1255. [CrossRef]

158. Warburton, D.M. Effects of caffeine on cognition and mood without caffeine abstinence. Psychopharmacology (Berlin) 1995, 119, 66-70. [CrossRef]

159. Loke, W.H. Effects of caffeine on mood and memory. Physiol. Behav. 1988, 44, 367-372. [CrossRef]

160. Mumford, G.K.; Evan, S.M.; Kaminski, B.J.; Preston, K.L.; Sannerud, C.A.; Silverman, K.; Griffiths, R.R. Discriminative stimulus and subjective effects of theobromine and caffeine in humans. Psychopharmacology (Berlin) 1994, 115, 1-8. [CrossRef]

161. Ruijter, J.; De Ruiter, M.B.; Snel, J. The effects of caffeine on visual selective attention to color: An ERP study. Psychophysiology 2000, 37, 427-439. [CrossRef] [PubMed]

162. Ruijter, J.; de Ruiter, M.B.; Snel, J.; Lorist, M.M. The influence of caffeine on spatial-selective attention: An event-related potential study. Clin. Neurophysiol. 2000, 111, 2223-2233. [CrossRef]

163. Hewlett, P.; Smith, A. Effects of repeated doses of caffeine on performance and alertness: New data and secondary analyses. Hum. Psychopharmacol.-Clin. Exp. 2007, 22, 339-350. [CrossRef] [PubMed] 
164. Lieberman, H.R.; Wurtman, R.J.; Emde, G.G.; Roberts, C.; Coviella, I.L.G. The effects of low-doses of caffeine on human-performance and mood. Psychopharmacology (Berlin) 1987, 92, 308-312. [CrossRef]

165. Peeling, P.; Dawson, B. Influence of caffeine ingestion on perceived mood states, concentration, and arousal levels during a 75-min university lecture. Adv. Physiol. Educ. 2007, 31, 332-335. [CrossRef] [PubMed]

166. Foreman, N.; Barraclough, S.; Moore, C.; Mehta, A.; Madon, M. High doses of caffeine impair performance of a numerical version of the stroop task in men. Pharmacol. Biochem. Behav. 1989, 32, 399-403. [CrossRef]

167. European Food Safety Authority (EFSA). Scientific opinion on the substantiation of health claims related to caffeine and increased fat oxidation leading to a reduction in body fat mass (ID 735, 1484), increased energy expenditure leading to a reduction in body weight (ID 1487), increased alertness (ID 736, 1101, 1187, 1485, $1491,2063,2103$ ) and increased attention (ID 736, 1485, 1491, 2375) pursuant to article 13(1) of regulation (EC) No. 1924/2006. EFSA J. 2011, 9, 2054.

168. European Food Safety Authority (EFSA). Scientific opinion on the substantiation of a health claim related to caffeine and increased alertness pursuant to article 13(5) of regulation (EC) No. 1924/2006. EFSA J. 2014, 12,3574 .

169. Seifert, S.M.; Schaechter, J.L.; Hershorin, E.R.; Lipshultz, S.E. Health effects of energy drinks on children, adolescents, and young adults. Pediatrics 2011, 127, 511-528. [CrossRef] [PubMed]

170. Van den Eynde, F.; van Baelen, P.C.; Portzky, M.; Audenaert, K. The effects of energy drinks on cognitive performance. Tijdschr. Psychiatr. 2008, 50, 273-281. [PubMed]

171. Kennedy, D.O.; Scholey, A.B. A glucose-caffeine 'energy drink' ameliorates subjective and performance deficits during prolonged cognitive demand. Appetite 2004, 42, 331-333. [CrossRef] [PubMed]

172. Rao, A.; Hu, H.L.; Nobre, A.C. The effects of combined caffeine and glucose drinks on attention in the human brain. Nutr. Neurosci. 2005, 8, 141-153. [CrossRef] [PubMed]

173. Warburton, D.M.; Bersellini, E.; Sweeney, E. An evaluation of a caffeinated taurine drink on mood, memory and information processing in healthy volunteers without caffeine abstinence. Psychopharmacology (Berlin) 2001, 158, 322-328. [CrossRef] [PubMed]

174. Aniţei, M.; Schuhfried, G.; Chraif, M. The influence of energy drinks and caffeine on time reaction and cognitive processes in young Romanian students. Procedia Soc. Behav. Sci. 2011, 30, 662-670. [CrossRef]

175. Gendle, M.H.; Smucker, D.M.; Stafstrom, J.A.; Helterbran, M.C.; Glazer, K.S. Attention and reaction time in university students following the consumption of red bull ${ }^{\circledR}$. Open Nutr. J. 2009, 9, 8-10. [CrossRef]

176. Howard, M.A.; Marczinski, C.A. Acute effects of a glucose energy drink on behavioral control. Exp. Clin. Psychopharmacol. 2010, 18, 553-561. [CrossRef] [PubMed]

177. Childs, E.; de Wit, H. Enhanced mood and psychomotor performance by a caffeine-containing energy capsule in fatigued individuals. Exp. Clin. Psychopharmacol. 2008, 16, 13-21. [CrossRef] [PubMed]

178. Smit, H.J.; Cotton, J.R.; Hughes, S.C.; Rogers, P.J. Mood and cognitive performance effects of "energy" drink constituents: Caffeine, glucose and carbonation. Nutr. Neurosci. 2004, 7, 127-139. [CrossRef] [PubMed]

179. Horne, J.A.; Reyner, L.A. Beneficial effects of an "energy drink" given to sleepy drivers. Amino Acids 2001, 20, 83-89. [CrossRef] [PubMed]

180. Scholey, A.; Savage, K.; O’Neill, B.V.; Owen, L.; Stough, C.; Priestley, C.; Wetherell, M. Effects of two doses of glucose and a caffeine-glucose combination on cognitive performance and mood during multi-tasking. Hum. Psychopharmacol.-Clin. Exp. 2014, 29, 434-445. [CrossRef] [PubMed]

181. Anderson, C.; Horne, J.A. A high sugar content, low caffeine drink does not alleviate sleepiness but may worsen it. Hum. Psychopharmacol.-Clin. Exp. 2006, 21, 299-303. [CrossRef] [PubMed]

182. Reyner, L.A.; Horne, J.A. Efficacy of a 'functional energy drink' in counteracting driver sleepiness. Physiol. Behav. 2002, 75, 331-335. [CrossRef]

183. Mets, M.A.; Ketzer, S.; Blom, C.; van Gerven, M.H.; van Willigenburg, G.M.; Olivier, B.; Verster, J.C. Positive effects of Red Bull ${ }^{\circledR}$ energy drink on driving performance during prolonged driving. Psychopharmacology (Berlin) 2011, 214, 737-745. [CrossRef] [PubMed]

184. Smit, H.J.; Grady, M.L.; Finnegan, Y.E.; Hughes, S.A.C.; Cotton, J.R.; Rogers, P.J. Role of familiarity on effects of caffeine- and glucose-containing soft drinks. Physiol. Behav. 2006, 87, 287-297. [CrossRef] [PubMed]

185. Sunram-Lea, S.I.; Owen-Lynch, J.; Robinson, S.; Jones, E.; Hu, H.L. The effect of energy drinks on cortisol levels, cognition and mood during a fire-fighting exercise. Psychopharmacology (Berlin) 2012, 219, 83-97. [CrossRef] [PubMed] 
186. Gonzalez-Bono, E.; Rohleder, N.; Hellhammer, D.H.; Salvador, A.; Kirschbaum, C. Glucose but not protein or fat load amplifies the cortisol response to psychosocial stress. Horm. Behav. 2002, 41, 328-333. [CrossRef] [PubMed]

187. Kirschbaum, C.; Bono, E.G.; Rohleder, N.; Gessner, C.; Pirke, K.M.; Salvador, A.; Hellhammer, D.H. Effects of fasting and glucose load on free cortisol responses to stress and nicotine. J. Clin. Endocrinol. Metab. 1997, 82, 1101-1105. [CrossRef] [PubMed]

188. Lupien, S.J.; Maheu, F.; Tu, M.; Fiocco, A.; Schramek, T.E. The effects of stress and stress hormones on human cognition: Implications for the field of brain and cognition. Brain Cogn. 2007, 65, 209-237. [CrossRef] [PubMed]

189. Robinson, S.; Sünram-Lea, S.I.; Leach, J.; Owen-Lynch, P.J. Cognitive and biochemical changes in individuals exposed to an acute stressor. Proc. Br. Psychol. Soc. 2004, 13, 24.

190. Scholey, A.B.; Kennedy, D.O. Cognitive and physiological effects of an "energy drink": An evaluation of the whole drink and of glucose, caffeine and herbal flavouring fractions. Psychopharmacology (Berlin) 2004, 176, 320-330. [CrossRef] [PubMed]

191. Adan, A.; Serra-Grabulosa, J.M. Effects of caffeine and glucose, alone and combined, on cognitive performance. Hum. Psychopharmacol.-Clin. Exp. 2010, 25, 310-317. [CrossRef] [PubMed]

192. Serra-Grabulosa, J.M.; Adan, A.; Falcon, C.; Bargallo, N. Glucose and caffeine effects on sustained attention: An exploratory fmri study. Hum. Psychopharmacol.-Clin. Exp. 2010, 25, 543-552. [CrossRef] [PubMed]

193. Giles, G.E.; Mahoney, C.R.; Brunye, T.T.; Gardony, A.L.; Taylor, H.A.; Kanarek, R.B. Differential cognitive effects of energy drink ingredients: Caffeine, taurine, and glucose. Pharmacol. Biochem. Behav. 2012, 102, 569-577. [CrossRef] [PubMed]

194. Young, H.A.; Benton, D. Caffeine can decrease subjective energy depending on the vehicle with which it is consumed and when it is measured. Psychopharmacology (Berlin) 2013, 228, 243-254. [CrossRef] [PubMed]

195. Maridakis, V.; O'Connor, P.J.; Tomporowski, P.D. Sensitivity to change in cognitive performance and mood measures of energy and fatigue in response to morning caffeine alone or in combination with carbohydrate. Int. J. Neurosci. 2009, 119, 1239-1258. [CrossRef] [PubMed]

196. James, J.E. Does caffeine enhance or merely restore degraded psychomotor performance. Neuropsychobiology 1994, 30, 124-125. [CrossRef] [PubMed]

197. James, J.E.; Rogers, P.J. Effects of caffeine on performance and mood: Withdrawal reversal is the most plausible explanation. Psychopharmacology (Berlin) 2005, 182, 1-8. [CrossRef] [PubMed]

198. Nehlig, A.; Boyet, S. Dose-response study of caffeine effects on cerebral functional activity with a specific focus on dependence. Brain Res. 2000, 858, 71-77. [CrossRef]

199. Graham, T.E.; Sathasivam, P.; Rowland, M.; Marko, N.; Greer, F.; Battram, D. Caffeine ingestion elevates plasma insulin response in humans during an oral glucose tolerance test. Can. J. Physiol. Pharmacol. 2001, 79, 559-565. [CrossRef] [PubMed]

200. Pizziol, A.; Tikhonoff, V.; Paleari, C.D.; Russo, E.; Mazza, A.; Ginocchio, G.; Onesto, C.; Pavan, L.; Casiglia, E.; Pessina, A.C. Effects of caffeine on glucose tolerance: A placebo-controlled study. Eur. J. Clin. Nutr. 1998, 52, 846-849. [CrossRef] [PubMed]

201. Blokland, A. Acetylcholine: A neurotransmitter for learning and memory? Brain Res. Brain Res. Rev. 1995, 21, 285-300. [CrossRef]

202. Rusted, J.M.; Eatonwilliams, P.; Warburton, D.M. A comparison of the effects of scopolamine and diazepam on working memory. Psychopharmacology (Berlin) 1991, 105, 442-445. [CrossRef]

203. Rusted, J.M.; Warburton, D.M. The effects of scopolamine on working memory in healthy-young volunteers. Psychopharmacology (Berlin) 1988, 96, 145-152. [CrossRef]

204. Biaggioni, I.; Paul, S.; Puckett, A.; Arzubiaga, C. Caffeine and theophylline as adenosine receptor antagonists in humans. J. Pharmacol. Exp. Ther. 1991, 258, 588-593. [PubMed]

205. Wenk, G.L. An hypothesis on the role of glucose in the mechanism of action of cognitive enhancers. Psychopharmacology (Berlin) 1989, 99, 431-438. [CrossRef]

206. Smith, A.; Brice, C.; Nash, J.; Rich, N.; Nutt, D.J. Caffeine and central noradrenaline: Effects on mood, cognitive performance, eye movements and cardiovascular function. J. Psychopharmacol. 2003, 17, $283-292$. [CrossRef] [PubMed]

207. Meyer, F.P.; Canzler, E.; Giers, H.; Walther, H. Time course of impaired elimination of caffeine by the oral depot contraceptive deposiston. Zentralbl. Gynakol. 1991, 113, 297-302. [PubMed] 
208. Van Soeren, M.H.; Graham, T.E. Effect of caffeine on metabolism, exercise endurance, and catecholamine responses after withdrawal. J. Appl. Physiol. 1998, 85, 1493-1501. [CrossRef] [PubMed]

209. Robertson, D.; Wade, D.; Workman, R.; Woosley, R.L.; Oates, J.A. Tolerance to the humoral and hemodynamic-effects of caffeine in man. J. Clin. Investig. 1981, 67, 1111-1117. [CrossRef] [PubMed]

210. Daly, J.W.; Fredholm, B.B. Caffeine-An atypical drug of dependence. Drug Alcohol Depend. 1998, 51, $199-206$. [CrossRef]

211. Ploutz-Snyder, L.; Foley, J.; Ploutz-Snyder, R.; Kanaley, J.; Sagendorf, K.; Meyer, R. Gastric gas and fluid emptying assessed by magnetic resonance imaging. Eur. J. Appl. Physiol. Occup. Physiol. 1999, 79, 212-220. [CrossRef] [PubMed]

212. Graham, T.E. Caffeine and exercise-Metabolism, endurance and performance. Sports Med. 2001, 31, $785-807$. [CrossRef] [PubMed]

213. Keijzers, G.B.; De Galan, B.E.; Tack, C.J.; Smits, P. Caffeine can decrease insulin sensitivity in humans. Diabetes Care 2002, 25, 364-369. [CrossRef] [PubMed]

214. Russell, J.A. A circumplex model of affect. J. Pers. Soc. Psychol. 1980, 39, 1161-1178. [CrossRef]

215. Watson, D.; Clark, L.A. Negative affectivity-The disposition to experience aversive emotional states. Psychol. Bull. 1984, 96, 465-490. [CrossRef] [PubMed]

216. Hamer, M.; Dye, L.; Siobhan Mitchell, E.; Layé, S.; Saunders, C.; Boyle, N.; Schuermans, J.; Sijben, J. Examining techniques for measuring the effects of nutrients on mental performance and mood state. Eur. J. Nutr. 2016, 55, 1991-2000. [CrossRef] [PubMed]

(C) 2018 by the authors. Licensee MDPI, Basel, Switzerland. This article is an open access article distributed under the terms and conditions of the Creative Commons Attribution (CC BY) license (http:/ / creativecommons.org/licenses/by/4.0/). 